\title{
TOMADA DE DECISÃO NA PEQUENA EMPRESA: \\ ESTUDO MULTI CASO SOBRE A UTILIZAÇÃO DE FERRAMENTAS INFORMATIZADAS DE APOIO À DECISÃO
}

Dissertação apresentada à Escola de Engenharia de São Carlos, da Universidade de São Paulo, como parte dos requisitos para a obtenção do título de Mestre em Engenharia de Produção.

Orientador: Prof. Dr. Wilson Kendy Tachibana

São Carlos - SP 
Ficha catalográfica preparada pela Seção de Tratamento da Informação do Serviço de Biblioteca - EESC/USP

M634t

Miglioli, Afrânio Maia

Tomada de decisão na pequena empresa : estudo multi caso sobre a utilização de ferramentas informatizadas de apoio à decisão / Afrânio Maia Miglioli. -- São Carlos, 2006 .

Dissertação (Mestrado) -- Escola de Engenharia de São Carlos-Universidade de São Paulo, 2006.

Área: Engenharia de Produção.

Orientador: Prof. Dr. Wilson Kendy Tachibana.

1. Pequena empresa. 2. Tomada de decisão. 3. Sistemas e ferramentas de apoio à decisão. I. Título. 
Candidato: Bacharel AFRÂNIO MAIA MIGLIOLI

Dissertação defendida e julgada em 30-03-2006 perante a Comissão Julgadora:
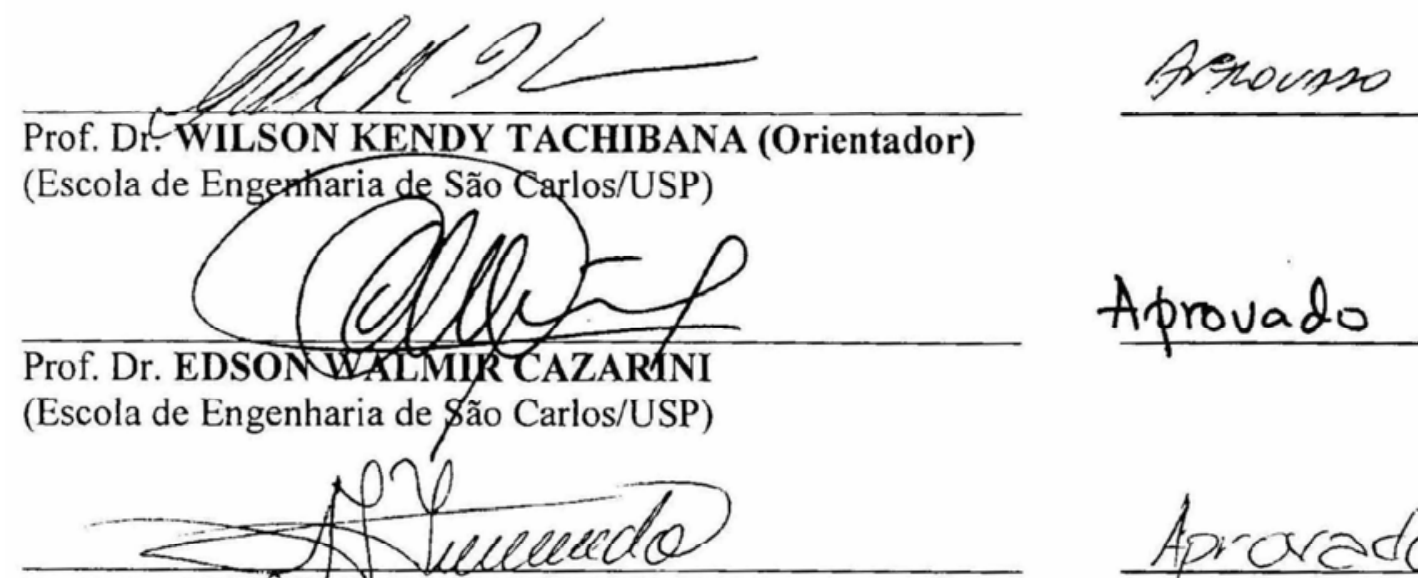

Prof. Dr. ANTONIOFERNANDO TRAINA

(Universidade de Ribeirão Preto/UNAERP )

\section{Aprovado}
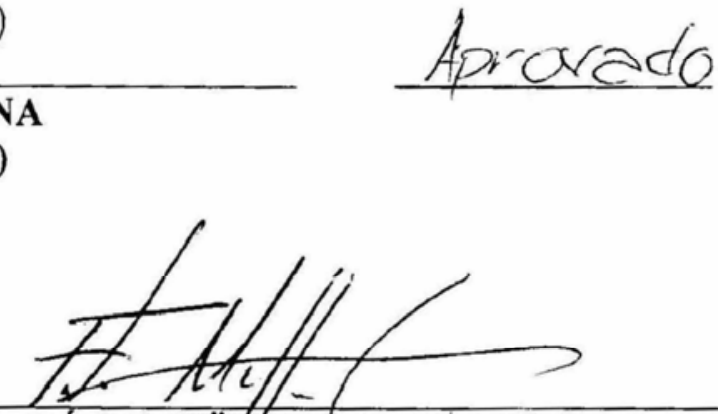

Prof. Dr. FÁBIO MÜLLER GUERRINI

Coordenador do Programa de Pos-Grddulação em Engenharia de Produçãe'

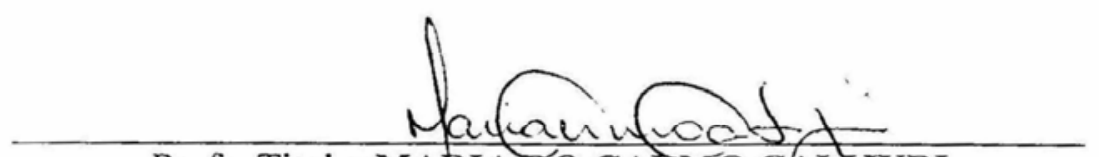

Profa. Titular MARIA DO CARMO CALXJURI

Presidente da Comissão de Pós-Graduaçầo 


\section{DEDICATÓRIA}

À minha mãe, exemplo de vida e de coragem.

À minha amada esposa, grande companheira e incentivadora deste trabalho. 


\section{AGRADECIMENTOS}

Primeiramente a Deus, seu Filho e a todos os seus Santos que me protegeram e deram força para concluir esta grande etapa de minha vida.

À minha família, pelo apoio e pelo porto seguro.

À minha esposa, pela compreensão das minhas ausências, principalmente na reta final.

Ao professor Wilson Kendy Tachibana, que sempre respeitou minhas idéias e meu estilo de trabalhar.

Aos professores Edson Walmir Cazarini e Antônio Fernando Traina, pelas sugestões e considerações que contribuíram para o resultado final deste trabalho.

Aos meus amigos Luiz Henrique e Bel, um dos grandes presentes deste mestrado.

Ao José Luiz, secretário da pós-graduação, pelo apoio e retaguarda, fazendo-me sentir próximo da EESC mesmo à distância.

Aos proprietários das três empresas pesquisadas, pelas informações prestadas e pelas portas abertas.

À eterna lembrança de meu pai.

Enfim, a todos que, direta ou indiretamente, contribuíram para a conclusão deste importante trabalho. 


\section{RESUMO}

Miglioli, A. M. (2006). Tomada de decisão na pequena empresa: estudo multi caso sobre a utilização de ferramentas informatizadas de apoio à decisão. 107 p. Dissertação (Mestrado). Escola de Engenharia de São Carlos, Universidade de São Paulo, São Carlos, 2006.

A presente dissertação tem como objetivo geral estudar de que forma as ferramentas ou sistemas informatizados de apoio à decisão podem auxiliar os tomadores de decisão da pequena empresa. A partir da revisão bibliográfica sobre o assunto e das inquietações do pesquisador, foram formuladas as variáveis e as questões desta pesquisa. No trabalho de campo foram estudadas três pequenas empresas da região de Ribeirão Preto, uma de cada segmento produtivo. Por meio do trabalho de campo, foi possível cruzar as informações obtidas na literatura com a realidade encontrada nas empresas pesquisadas, levantando informações sobre a utilização das ferramentas informatizadas de apoio à decisão nestas empresas. Ao longo deste estudo, procurou-se analisar os fatores que dificultam ou incrementam a utilização destas ferramentas nas pequenas empresas, respeitando as suas particularidades de gestão e o seu processo decisório. Após a condução do trabalho, pôde-se concluir que a utilização efetiva destas ferramentas está diretamente relacionada ao perfil e às habilidades de seus proprietários-administradores. Diante disso e dos dados apresentados ao longo desta pesquisa, foram apresentadas algumas propostas para a condução de projetos que visem à utilização de ferramentas de apoio à decisão na pequena empresa. Estas propostas baseiam-se na criação de ambientes de aprendizagem voltados à realidade das pequenas empresas, onde o proprietário-administrador possa adquirir conhecimentos necessários para manipular as ferramentas de apoio à decisão; e na necessidade de se reforçar e demonstrar a importância da tomada de decisões com base em informações relevantes e confiáveis.

Palavras chave: Pequena Empresa, Tomada de Decisão, Sistemas e Ferramentas de Apoio à Decisão. 


\begin{abstract}
MIGLIOLI, M. A. (2006). Decision making in the small company: multi case study of the use of computing tools in the decision support. 107 p. Dissertation (Master). São Carlos Engineering School, São Paulo University, São Carlos, 2006.

The present dissertation has as its general idea to study in which ways the tools or computing systems for decision support can assist the people that take the decision in the small company. Based on a bibliographical revision of the subject and the fidgets of the researcher, it was possible to formulated the variables and the questions of this research. In the field work three small companies of the region of Ribeirão Preto had been studied, one of each different productive segment. By means of the field work, it was possible to cross the information gotten in all the literature with the reality found in the companies researched, raising information of the use of the computing tools in the decision support of these companies. Along of this study it was analyzed the factors that makes it difficult to develop the use of these tools in the small companies, respecting its particularities of management and its power of decision. By the end of this work, it was possible to conclude that the use of these tools are directly related with the profile and the abilities of its proprietor-administrators. According to the data presented during this research, it was mentioned some proposals for the conduction of projects that aim the use of the tools for the decision support in the small company. These proposals are based on the environment studied in the small companies, where the proprietoradministrator can acquire knowledge necessary to manipulate the tools of the decision support; and in the necessity of strengthening the importance of the taking of decision based on the excellent and trustworthy information.
\end{abstract}

Keywords: Small Company, Decision Making, Systems and Tools of Support to the Decision. 


\section{LISTA DE FIGURAS}

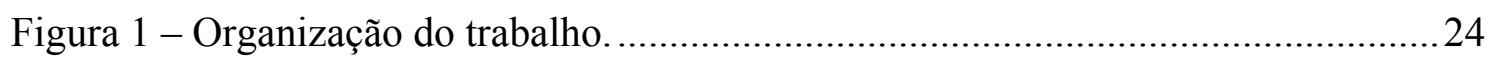

Figura 2 - Inter-relação entre as especificidades das pequenas empresas. ..................... 35

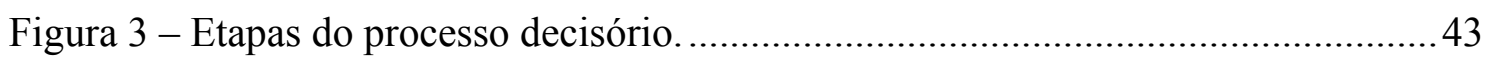

Figura 4 - A expansão das funções dos sistemas de informação................................... 46

Figura 5 - Características OLAP presentes nas planilhas eletrônicas. ............................58

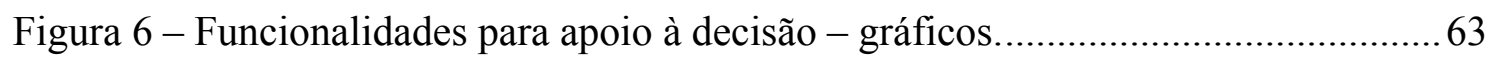

Figura 7 - Funcionalidades para apoio à decisão - tabelas dinâmicas. .......................... 64

Figura 8 - Funcionalidades para apoio à decisão - filtros e portal corporativo. .............66

Figura 9 - Aspectos metodológicos adotados nesta pesquisa...................................... 75 


\section{LISTA DE GRÁFICOS}

Gráfico 1 - Grau de informatização da pequena empresa paulista..................................38

Gráfico 2 - Atividades em que o microcomputador é utilizado nas MPEs paulistas.....39 


\section{LISTA DE QUADROS}

Quadro 1 - Critérios de classificação de empresas...................................................... 28

Quadro 2 - Definição de pequena empresa de acordo com o Estatuto das MPEs...........30

Quadro 3 - Classificação das empresas de acordo com o SEBRAE. ............................. 30

Quadro 4 - Principais diferenças entre dados, informação e conhecimento.................... 48

Quadro 5 - Principais diferenças entre sistemas transacionais (SIGs) e SADs..............51

Quadro 6 - O tomador de decisão das PEs e as ferramentas de apoio à decisão

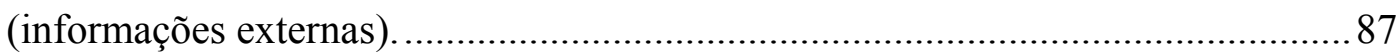

Quadro 7 - Infra-estrutura tecnológica e facilidade do tomador de decisão manipular as

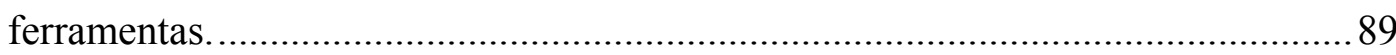

Quadro 8-O tomador de decisão das PEs e as ferramentas de apoio à decisão

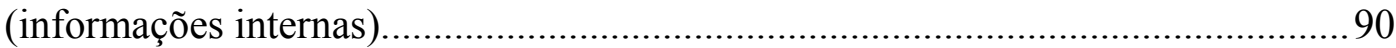

Quadro 9 - Particularidades das PEs e as ferramentas de apoio à decisão..................... 94

Quadro 10 - Grau de utilização das ferramentas X facilidade de manipulá-las. ............95 


\section{LISTA DE TABELAS}

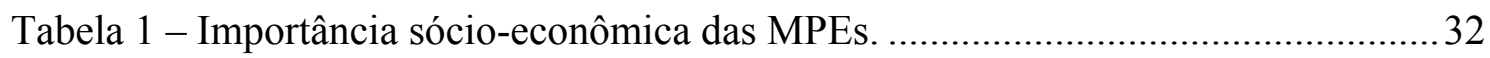

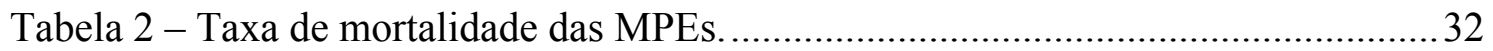




\section{LISTA DE ABREVIATURA E SIGLAS}

CRIE - Centro de Referência em Inteligência Empresarial

CRM - Customer Relationship Management

DSS - Decision Support Systems

ERP - Enterprise Resources Planning

IBGE - Instituto Brasileiro de Geografia e Estatística

MPE - Micro e Pequena Empresa

MS - Microsoft Corporation

MTE - Ministério do Trabalho e Emprego

OLAP - On Line Analytical Processing

PC - Computador Pessoal

PE - Pequena Empresa

PIB - Produto Interno Bruto

PNAD - Pesquisa Nacional por Amostra de Domicílios

RAIS - Relação Anual de Informações sociais

SAD - Sistemas de Apoio à Decisão

SBA - Small Business Administration

SEBRAE - Serviço Brasileiro de Apoio às Micro e Pequenas Empresas

SIG - Sistemas de Informação Gerencial 


\section{SUMÁRIO}

CAPÍTULO 1 - INTRODUÇÃO ...........................................................................15

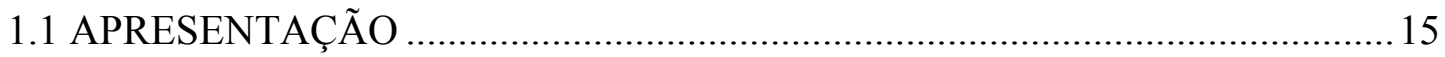

1.2 CARACTERIZAÇÃO E DELIMITAÇÃO DO TEMA DA PESQUISA ............. 17

1.3 RELEVÂNCIA DA PESQUISA AO ABORDAR O TEMA................................ 19

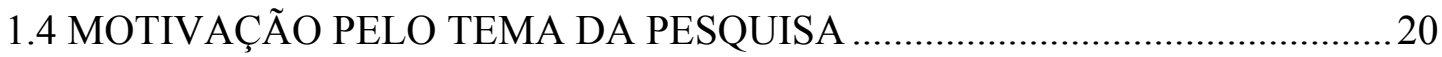

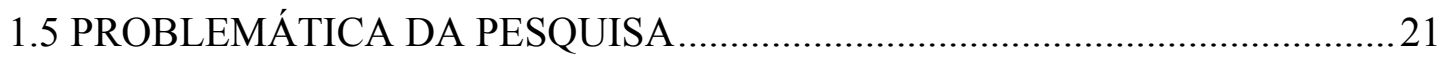

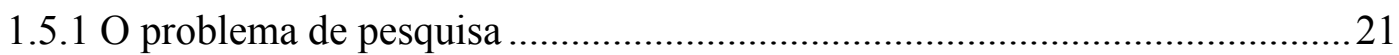

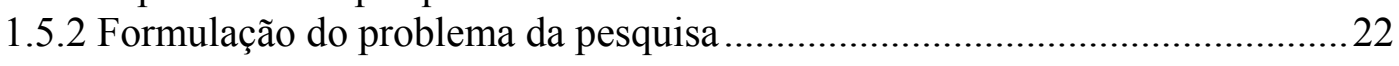

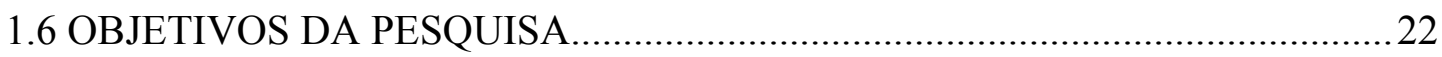

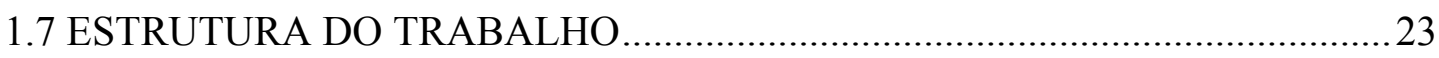

CAPÍTULO 2 - REVISÃO BIBLIOGRÁFICA ......................................................25

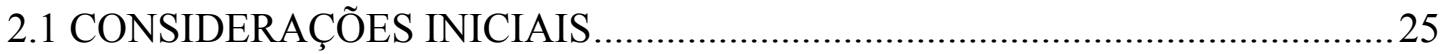

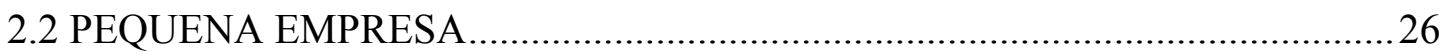

2.2.1 Critérios para definição de pequena empresa ….........................................22

2.2.2 Importância da pequena empresa no cenário sócio-econômico brasileiro..... 30

2.2.3 Sobrevivência e mortalidade da pequena empresa ...................................... 32

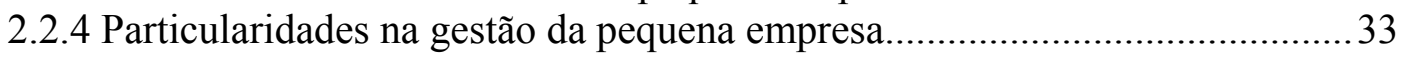

2.2.5 Tecnologia da informação na pequena empresa .......................................... 36

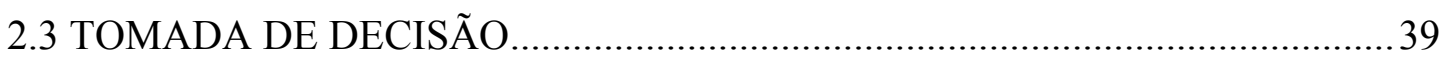

2.3.1 Tipos e métodos principais de decisão..................................................... 40

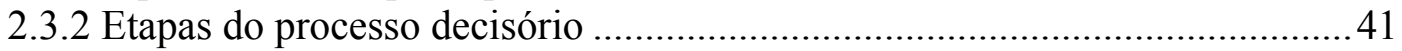

2.3.3 Importância da tomada de decisão para as empresas.................................... 43

2.3.4 Processo decisório na pequena empresa ........................................................4

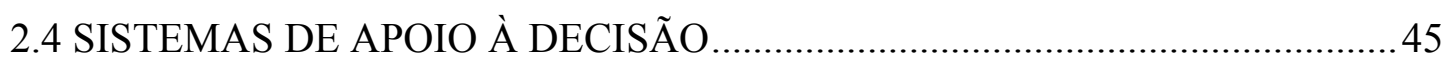

2.4.1 Dados, informação e conhecimento ............................................................ 47

2.4.2 Conceito de sistemas e de ferramentas de apoio à decisão .............................49

2.4.3 Sistemas transacionais versus sistemas de apoio à decisão ..........................50

2.4.4 Características, objetivos e benefícios dos sistemas de apoio à decisão.........52

2.4.5 Principais usos nas empresas dos sistemas de apoio à decisão......................53

2.5 FERRAMENTAS DE APOIO À DECISÃO ....................................................56

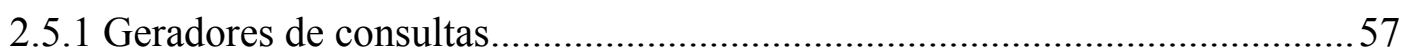

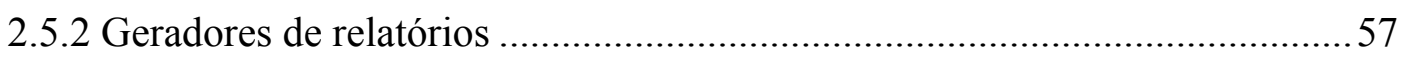

2.5.3 Softwares que utilizam características OLAP .............................................5

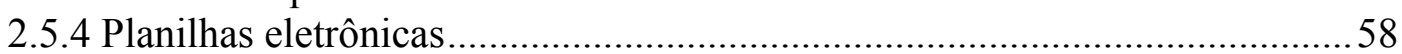

2.5.4.1 Conceito e evolução das planilhas eletrônicas .........................................6 60

2.5.4.2 As planilhas eletrônicas como ferramentas de apoio à decisão ...............61

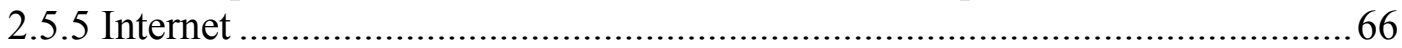


CAPÍTULO 3 - METODOLOGIA DA PESQUISA ……………………….....................70

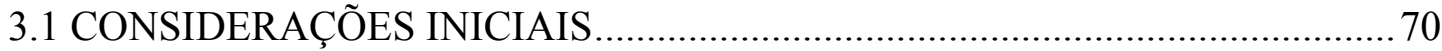

3.2 FORMA DE ABORDAGEM DA PESQUISA.....................................................

3.3 TIPO DE INVESTIGAÇÃO DA PESQUISA ………………………………….... 71

3.4 ESTRATÉGIA DA PESQUISA ………………………................................. 72

3.5 CARACTERIZAÇÃO DA PESQUISA ……………………………………........

3.6 PLANEJAMENTO DO ESTUDO DE CASO ......................................................

3.6.1 Universo da pesquisa .............................................................................

3.6.2 Definição da amostra da pesquisa ................................................................

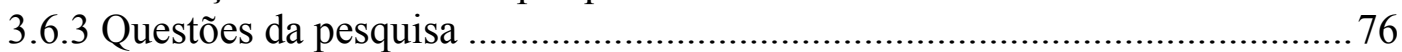

3.6.4 Fatores qualitativos e pressupostos da pesquisa .............................................77

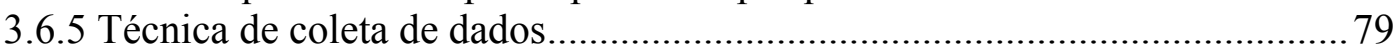

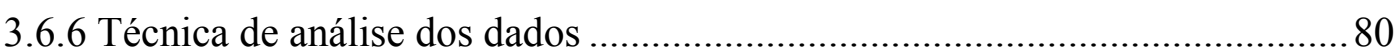

3.6.7 Estrutura para o relato do estudo de caso....................................................... 81

CAPÍTULO 4 - TRABALHO DE CAMPO...............................................................82

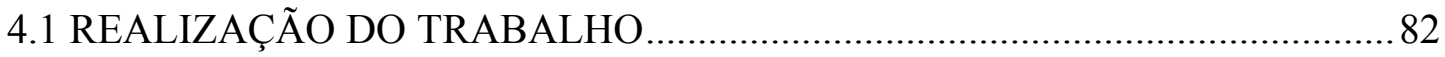

4.2 DESCRIÇÃO DAS EMPRESAS ESTUDADAS.................................................. 83

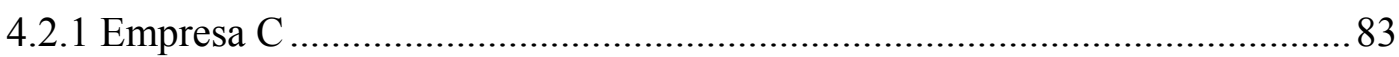

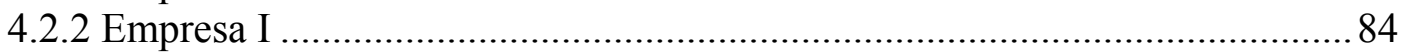

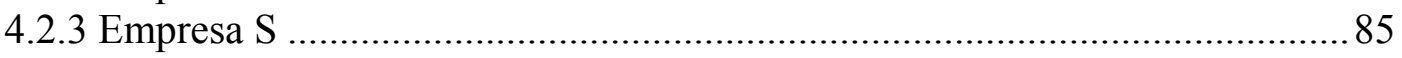

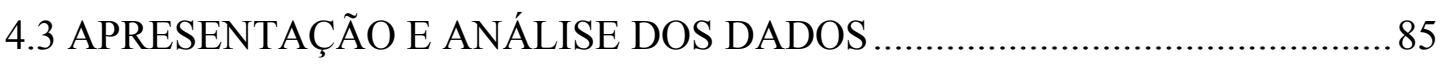

4.3.1 O tomador de decisão da $\mathrm{PE} e$ as ferramentas de apoio à decisão ....................86

4.3.2 As particularidades da PE e as ferramentas de apoio à decisão......................94

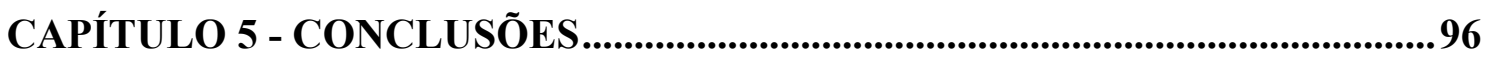

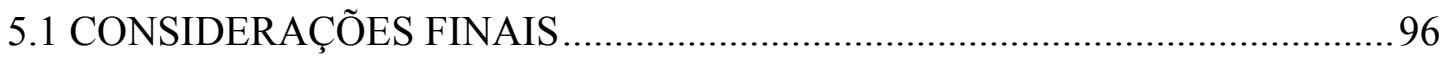

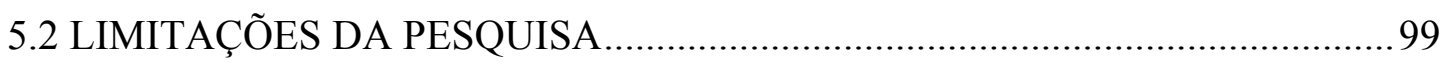

5.3 PROPOSIÇÃO DE ATIVIDADES FUTURAS ……………………………….....99

REFERÊNCIAS BIBLIOGRÁFICAS ..............................................................100 


\section{CAPÍTULO 1 - INTRODUÇÃO}

\subsection{APRESENTAÇÃO}

O período compreendido entre o final do século $\mathrm{XX}$, sobretudo a partir da década de 70, e o início do século XXI, foi marcado por profundas transformações nos modelos social, político, econômico, produtivo e, principalmente, tecnológico, da sociedade mundial.

O cientista social Manuel Castells, em sua obra publicada no final do século passado, intitula de informacionalismo o novo modo de desenvolvimento resultante dessas transformações (CASTELLS, 1999). O autor considera que essas mudanças tiveram suas origens na revolução tecnológica ocorrida nas últimas décadas do século XX e são caracterizadas por promover a produtividade a partir da geração do conhecimento, do processamento da informação e da comunicação de símbolos. De acordo com Marques (1999), essas alterações provocaram, entre tantas outras modificações, a decadência do sistema de produção em massa, a diminuição do uso da matéria, o aumento da importância e da utilização da informação, seja no universo empresarial ou no cotidiano das pessoas.

Inseridas nesse cenário, as organizações, a fim de se tornarem competitivas e eficazes, estão adotando um novo modelo de gestão, o qual alia o uso dos recursos tecnológicos à sua capacidade de inovação, criação e transformação da informação em insumo capaz de alimentar e sustentar seus processos operacionais e decisórios (RODRIGUEZ, 2002). Desse modo, é incontestável a premissa de que para executar as funções da administração - planejamento, organização, direção e controle -, os sistemas que fornecem informações aos administradores, constituem-se como elementos vitais para a gestão empresarial (PRATES e OSPINA, 2004).

Segundo Stoner (1999), somente com informações precisas e na hora certa, os administradores podem monitorar o progresso na direção de seus objetivos e, transformar os planos em realidade. Por isso, e em função do aumento da complexidade e do dinamismo das variáveis externas, as organizações estão cada vez mais dependentes de mecanismos eficazes de administração da informação, pois necessitam 
reduzir o quadro de incerteza em que suas decisões são tomadas e melhorar o relacionamento com parceiros, clientes, fornecedores e outros agentes (BEAL, 2004).

$\mathrm{Na}$ pequena empresa esse cenário não é diferente, prova disso é a evolução ocorrida nessas empresas ao longo dos últimos anos com relação à disseminação e ao uso das tecnologias de informação. Palvia e Palvia ${ }^{1}$ (1999 apud PRATES e OSPINA, 2004), em levantamento realizado em dezesseis regiões do mundo, sobre a informatização nas empresas ao longo dos últimos cinco anos, expõem resultados que indicam um crescimento de 30 a $80 \%$ na utilização de computadores pelas pequenas empresas pesquisadas.

A realidade brasileira também confirma o panorama de crescimento da informatização na pequena empresa. De acordo com os resultados apresentados por uma pesquisa realizada pelo Serviço Brasileiro de Apoio às Micro e Pequenas Empresas (SEBRAE), sobre a informatização em micro e pequenas empresas do estado de São Paulo, nota-se entre 1997 e 2002, um crescimento da ordem de 51\% no nível de informatização dessas empresas (SEBRAE, 2004a).

A evolução da informatização apontada nessas pesquisas, somada aos avanços ocorridos nas tecnologias de informação nos últimos trinta anos, têm sido responsáveis por mudanças significativas na maneira pela qual a informação é produzida e disseminada atualmente nas organizações, sejam elas grandes corporações ou pequenas empresas. Entre as principais mudanças, cabe destacar a facilidade de acesso às fontes de conhecimento de maneira mais rápida e com menor custo, além das variadas opções disponíveis para a criação, manipulação, distribuição, recuperação e preservação da informação (BEAL, 2004).

Destaca-se, em meio a outros avanços, o surgimento dos sistemas de apoio à decisão, os quais são, entre diversas definições existentes, mecanismos computacionais destinados a levantar informações relevantes com o objetivo de prestar suporte ao processo de tomada de decisão. Ou, em outras palavras, ferramentas computacionais capazes de, a partir de um grande volume de dados operacionais produzidos diariamente, organizar, sintetizar, armazenar e proporcionar meios de acesso e disseminação de informação relevante e contextualizada aos tomadores de decisão.

Para Come (2001, p. 1), o sistema de apoio à decisão está relacionado ao processo de "agrupar, estruturar, manipular, armazenar, acessar, apresentar e distribuir

\footnotetext{
${ }^{1}$ PALVIA, P. C.; PALVIA, S. C. (1999). An examination of the IT satisfaction of small business users. Information \& Management, v. 5, n. 35, p. 127-137.
} 
informações de negócios de maneira oportuna, ou seja, a informação certa no momento certa e na quantidade certa".

A utilização dos sistemas de apoio à decisão se justifica em função da problemática que gira em torno do próprio processo decisório nas empresas. De acordo com Bispo (1998), tal processo envolve uma série de variáveis - internas e externas -, além de interesses econômicos e políticos, que nem sempre estão totalmente explicitados. Além disso, a rapidez na dinâmica do mundo empresarial e as dificuldades de acesso a informações relevantes e em tempo hábil, tornam essas ferramentas importantes aliadas dos tomadores de decisão.

Entretanto, cabe destacar que os sistemas de apoio à decisão não podem ser encarados como pacotes genéricos de softwares, os quais geralmente são adequados e aderentes a vários tipos de empresas. Tampouco se pode considerá-los como um sistema que irá tomar decisões e resolver os problemas da empresa. Essas ferramentas simplesmente fornecem o instrumental e as informações necessárias para que os executivos e/ou proprietários de empresas tomem suas decisões. De acordo com Aquarioni (2001), os sistemas de apoio à decisão não tomam decisões por si próprios, apenas auxiliam os profissionais a tomarem decisões inteligentes e baseadas em informações confiáveis.

Portanto, as empresas, principalmente as de pequeno porte, precisam por um lado, procurar por sistemas e ferramentas adequadas às suas características e particularidades, e por outro lado, preparar seus tomadores de decisão para lidar com informações que possam apoiá-los.

\subsection{CARACTERIZAÇÃO E DELIMITAÇÃO DO TEMA DA PESQUISA}

Segundo Fuller² (1996 apud PRATES e OSPINA, 2004), o aumento do uso de computadores nas pequenas empresas ocorre principalmente nas atividades operacionais e administrativas e não em tarefas estratégicas e de tomada de decisão. Deste modo, o avanço da informatização ocorrido ao longo dos últimos anos nessas empresas, pode estar representando um quadro de subutilização dos seus recursos tecnológicos.

Além disso, no dia-a-dia da pequena empresa, seus tomadores de decisão estão imersos em grandes volumes de dados operacionais, os quais geralmente encontram-se

\footnotetext{
${ }^{2}$ FULLER, T. (1996). Fullfilling IT needs in small businesses: a recursive learning model. International Small Business Journal, v. 14, n. 4, p. 25-44.
} 
isolados e sem contextualização. Dessa forma, esses dados não servem de sustentação para o processo decisório, pois estando dispersos e sem interpretação, refletem apenas uma parte do que ocorreu no passado (COLMANETTI, 2003).

Adicionalmente a esse cenário, é importante ressaltar a notória dificuldade enfrentada pela pequena empresa com relação à obtenção e ao uso de informações que possam sustentar os seus processos decisórios, sendo que essas informações, segundo $83,7 \%$ dos entrevistados de uma pesquisa publicada sobre gestão do conhecimento, encontram-se dentro da própria empresa (HSM, 2004).

O que pode explicar em parte essas dificuldades é a falta de tecnologia e de ferramentas que atendam às necessidades e sejam acessíveis à realidade dessas empresas, principalmente, no tocante aos processos estratégicos e de apoio às decisões (EL-MANAKI ${ }^{3}, 1990$ apud PRATES e OSPINA, 2004). Em função desses cenários, muitas vezes, a pequena empresa não consegue viabilizar e/ou otimizar o uso dos seus recursos informacionais.

Contudo, é importante destacar um aspecto inerente ao ambiente da pequena empresa, o qual geralmente, contribui para aumentar a dificuldade de implementação de qualquer projeto voltado para apoiar o processo decisório. Esse aspecto diz respeito às especificidades de gestão presentes nessas empresas, dentre as quais, a que torna o processo de decisão baseado no sentimento e na experiência do proprietárioadministrador (ALBUQUERQUE, 2004; LEONE, 1999).

Segundo Leone (1999), nas pequenas empresas:

Os processos de planejamento e de controle são geralmente pouco formalizados e quantificados. A escolha do melhor método de planejamento depende de variáveis como o estilo de direção, as capacidades dos responsáveis e a complexidade da atividade. (LEONE, 1999, p. 92).

Diante desse contexto, algumas variáveis precisam ser analisadas antes da implementação de qualquer projeto que tenha como objetivo apoiar o processo decisório na pequena empresa, entre elas, as particularidades de gestão dessas empresas, o processo decisório não estruturado, o volume limitado de recursos financeiros para investimentos em novas tecnologias e a necessidade de ferramentas simples e amigáveis aos tomadores de decisão.

\footnotetext{
${ }^{3}$ EL-MANAKI, M. S. S. (1990). Small business: the myths and the reality. Long Range Planning, v. 23, n. 4, p. $78-87$.
} 
Portanto, o presente trabalho visa explorar de que forma as ferramentas ou sistemas informatizados podem auxiliar o tomador de decisão da pequena empresa, respeitando-se as especificidades ambientais e de gestão destas empresas.

\subsection{RELEVÂNCIA DA PESQUISA AO ABORDAR O TEMA}

O advento da era da informação está redefinindo as trajetórias das carreiras profissionais, dos níveis salariais, da estrutura, do funcionamento dos negócios e o próprio sentido do trabalho, causando a mudança no pensamento de que as melhores oportunidades de sucesso profissional estão em grandes corporações. Essas oportunidades estão sendo muitas vezes, encontradas nas empresas de pequeno porte.

Deste modo, as pequenas empresas exercem um papel fundamental na nova ordem sócio-econômica mundial, pois se apresentam como alternativas para a absorção da mão-de-obra excedente decorrente da decadência do modelo de produção em massa.

Além disso, essas empresas têm contribuído para a economia como um todo fornecendo novos empregos, introduzindo inovações, estimulando a competitividade, auxiliando na rede de distribuição e na cadeia de suprimentos das grandes empresas (LONGENECKER, MOORE e PETTY, 1997).

No Brasil, além desses aspectos, as pequenas empresas representam um segmento fundamental para o processo de desenvolvimento do país, pois operam em todos os setores da economia brasileira, representando junto com as micro-empresas, 99\% do total de empresas, $67 \%$ da taxa de emprego e 20\% do PIB (SEBRAE, 2004b).

Cabe destacar, a representatividade dos setores de comércio, serviços e agronegócios no total das micro e pequenas empresas do estado de São Paulo. Em conjunto, esses setores - altamente presentes na economia da região de Ribeirão Preto respondem por $88 \%$ do total das micro e pequenas empresas presentes no estado.

Entretanto, dados do SEBRAE (2004b) mostram que sete em cada dez empresas encerram suas atividades antes de completarem o quinto ano. De acordo com o órgão, as principais causas da mortalidade dessas empresas são:

- $\quad$ Falta de planejamento prévio;

- $\quad$ Gestão deficiente do negócio;

- $\quad$ Atividade econômica deprimida;

- $\quad$ Insuficiência de políticas de apoio;

- $\quad$ Problemas pessoais. 
A pequena empresa que consegue firmar-se além dos cinco primeiros anos depara-se muitas vezes com problemas organizacionais decorrentes do crescimento sem planejamento. A influência da incerteza nos aspectos internos sobre as estruturas organizacionais afeta o comportamento estratégico das pequenas empresas. $\mathrm{O}$ ambiente externo obriga o dirigente da pequena empresa a adotar uma postura centralizadora de administrar o negócio, preferindo agir por conta própria, guiado mais pela sua sensibilidade do que pelos meios técnicos de administração (LEONE, 1999).

Uma alternativa para diminuir o quadro de mortalidade na pequena empresa brasileira é a melhoria no processo de gestão dessas empresas, tendo como apoio a utilização efetiva da informação. Entretanto, segundo Albuquerque (2004), essas empresas não dispõem de ferramentas adequadas de gestão da informação.

Ao se analisar a peculiaridade do processo de tomada de decisão da pequena empresa, percebe-se claramente que o proprietário-administrador é o principal responsável pela atividade de decidir, estando presente, muitas vezes, nas decisões dos três níveis organizacionais (ZAMARIOLI, 2003).

Além disso, nota-se que o processo de tomada de decisão nestas empresas é de certa forma empírico e extremamente dependente da percepção do proprietário em levantar e analisar todas as informações disponíveis.

Diante desse contexto, este trabalho pretende estudar de que forma as ferramentas ou sistemas de apoio à decisão podem auxiliar o trabalho dos tomadores de decisão das pequenas empresas, contribuindo assim para a melhoria na gestão e para a diminuição da taxa de mortalidade dessas empresas.

\subsection{MOTIVAÇÃO PELO TEMA DA PESQUISA}

O pesquisador ao longo dos últimos quatorze anos tem vivenciado constantemente várias mudanças provocadas pela revolução informacional. Esse envolvimento foi possível graças à sua formação profissional, a qual sempre esteve relacionada com o ambiente das pequenas empresas, seja enquanto colaborador, empreendedor-empresário ou consultor.

Aliado à experiência profissional, a formação acadêmica do pesquisador como bacharel em Análise de Sistemas, proporcionou-lhe entender e enxergar as organizações como organismos sistêmicos, onde inúmeras variáveis encontram-se presentes e 
interdependentes, comprovando na prática a teoria de que qualquer análise sobre uma empresa deve ser feita de modo a visualizá-la amplamente e de forma holística.

A oportunidade de realizar o mestrado em Engenharia de Produção, somada à vivência acadêmico-empresarial do pesquisador, proporcionou-lhe ingressar no universo da pesquisa científica, onde foi possível lapidar e aprofundar algumas inquietações que estão fortemente relacionadas à escolha do tema e o enfoque dado a esta pesquisa.

O ponto central dessas inquietações envolve a busca e o estudo de alternativas que possam contribuir com a diminuição da alta taxa de mortalidade presente nas pequenas empresas brasileiras, aliando a gestão de negócios ao uso eficiente e estratégico da informação.

A motivação do pesquisador em estudar o tema desta pesquisa, é sustentada por dois pilares:

- $\quad$ Primeiro, pela crença de que o desenvolvimento sustentável das pequenas empresas é uma das melhores alternativas para conduzir o Brasil rumo à sua independência financeira, gerando divisas e contribuindo para a diminuição do desemprego;

E em segundo lugar, pela vontade de contribuir para a produção cientifica e bibliográfica sobre a utilização de mecanismos que possam vir a ajudar as pequenas empresas na utilização efetiva de suas informações.

\subsection{PROBLEMÁTICA DA PESQUISA}

\subsubsection{O problema de pesquisa}

A atividade de determinar o problema de pesquisa constitui-se, segundo alguns autores, numa das primeiras e mais importantes fases do trabalho científico, tendo em visto o sucesso do projeto como um todo (CERVO e BERVIAN, 2002; GIL, 2002; MARCONI e LAKATOS, 2002). Gil (2002, p. 17), destaca a importância da formulação do problema para o trabalho científico, ao definir o termo pesquisa como sendo o "procedimento racional e sistemático que tem como objetivo proporcionar respostas aos problemas que são propostos.”.

Segundo Cervo e Bervian (2002), uma vez definido e delimitado o tema de pesquisa, a próxima etapa é a formulação do problema, a qual pode ser expressa através da formulação de perguntas. Os autores afirmam que enquanto o tema de pesquisa não for problematizado, a investigação propriamente dita não se iniciou. 
O tema escolhido deve ser questionado [...] pela mente do pesquisador, que deve transformá-lo em problema de pesquisa, mediante seu esforço de reflexão, sua curiosidade ou talvez seu gênio. Descobrir os problemas que o tema envolve, identificar as dificuldades que ele sugere, formular perguntas ou levantar hipóteses significa abrir a porta, através da qual o pesquisador pode penetrar no terreno do conhecimento científico. (CERVO e BERVIAN, 2002, p. 84).

Complementando a relevância da definição do problema de pesquisa, cabe destacar as considerações de Guerrini (2002, p. 16), ao dizer que essa etapa "é a parte mais trabalhosa, pois o pesquisador pode estar circundando o problema e se o problema for mal formulado, o resultado da tese ou dissertação pode ser comprometido.”. Além desses aspectos, o autor destaca que a formulação do problema serve de base para a declaração do objetivo da pesquisa, sendo esse, uma afirmação do que é perguntado no problema.

\subsubsection{Formulação do problema da pesquisa}

Diante do exposto, acerca da importância e da forma como pode ser expressa a problemática do tema de uma pesquisa, aliado como os argumentos apresentados na seção 1.3, sobre a relevância desta pesquisa, este trabalho levanta a seguinte questão:

De que forma as ferramentas ou sistemas informatizados de apoio à decisão podem auxiliar o tomador de decisão da pequena empresa, considerando suas particularidades de gestão?

\subsection{OBJETIVOS DA PESQUISA}

Segundo Guerrini (2002, p. 16), a “declaração do objetivo é uma afirmação do que é perguntado no problema.".

Deste modo, o objetivo geral deste trabalho é, a partir da análise das particularidades de gestão e do processo decisório existente nas pequenas empresas, explorar de que forma as ferramentas ou sistemas informatizados de apoio à decisão podem auxiliar os tomadores de decisão destas empresas.

Para alcançar esse objetivo geral, os seguintes objetivos secundários devem ser atingidos:

Revisar a literatura sobre as características, particularidades de gestão, importância e grau de informatização das pequenas empresas;

- $\quad$ Estudar de forma geral a tomada de decisão e o processo decisório; 
- Compreender as peculiaridades da pequena empresa no tocante ao seu processo de tomada de decisão;

Realizar um levantamento bibliográfico sobre os sistemas e ferramentas de apoio à decisão, a fim de subsidiar a pesquisa exploratória de campo;

- Confrontar os dados obtidos empiricamente sobre as pequenas empresas exploradas, as especificidades do seu processo de tomada de decisão e as possíveis ferramentas utilizadas pelos tomadores de decisão, com o referencial teórico levantado.

\subsection{ESTRUTURA DO TRABALHO}

Este trabalho está estruturado em cinco capítulos. A sistemática escolhida para organizar o seu conteúdo e a seqüência dos assuntos foi baseada em estudos realizados em várias obras de referência, e ajustada à problemática e à estratégia metodológica adotada para esta pesquisa (CERVO e BERVIAN, 2002; GIL, 2002; GODOY, 1995; GUERRINI, 2002; MARCONI e LAKATOS, 2002; TAFNER, TAFNER e FISCHER, 1995; YIN, 2005).

No primeiro capítulo, o tema da pesquisa é contextualizado e caracterizado de acordo com seu enfoque. Além disso, são apresentadas:

- $\quad$ A importância deste trabalho ao abordar o tema;

- $\quad$ As motivações que levaram o pesquisador a escolher o tema;

- $\quad$ A formulação da problemática da pesquisa;

- $\quad$ A identificação dos fatores qualitativos e pressupostos da pesquisa;

- $\quad$ E por fim, o objetivo da pesquisa.

Na seqüência, o capítulo 2 através de levantamento bibliográfico na literatura disponível, apresenta a revisão "preliminar e sintética" dos tópicos inerentes ao tema desta pesquisa de modo a fundamentar teoricamente o necessário para o entendimento da questão delimitada (CERVO e BERVIAN, 2002, p. 72).

O capítulo 3 discorre sobre os aspectos metodológicos adotados nesta pesquisa, destacando a importância do estudo prévio das várias estratégias metodológicas disponíveis, a fim de possibilitar a escolha do método que melhor se enquadre na problemática da pesquisa. Nesse capítulo, também são apresentadas as diretrizes metodológicas utilizadas para a realização do estudo de caso, o qual será exposto no capítulo 4. 
- $\quad$ O capítulo 4 registra e apresenta o trabalho de campo realizado através do estudo exploratório. Nesse capítulo, são expostas as atividades executadas nas etapas de condução do estudo exploratório.

No capítulo 5, encontram-se as considerações finais, baseadas na apresentação e discussão do ambiente explorado, confrontando-se com o referencial teórico estudado.

A Figura 1, abaixo, resume e esquematiza a organização deste trabalho.

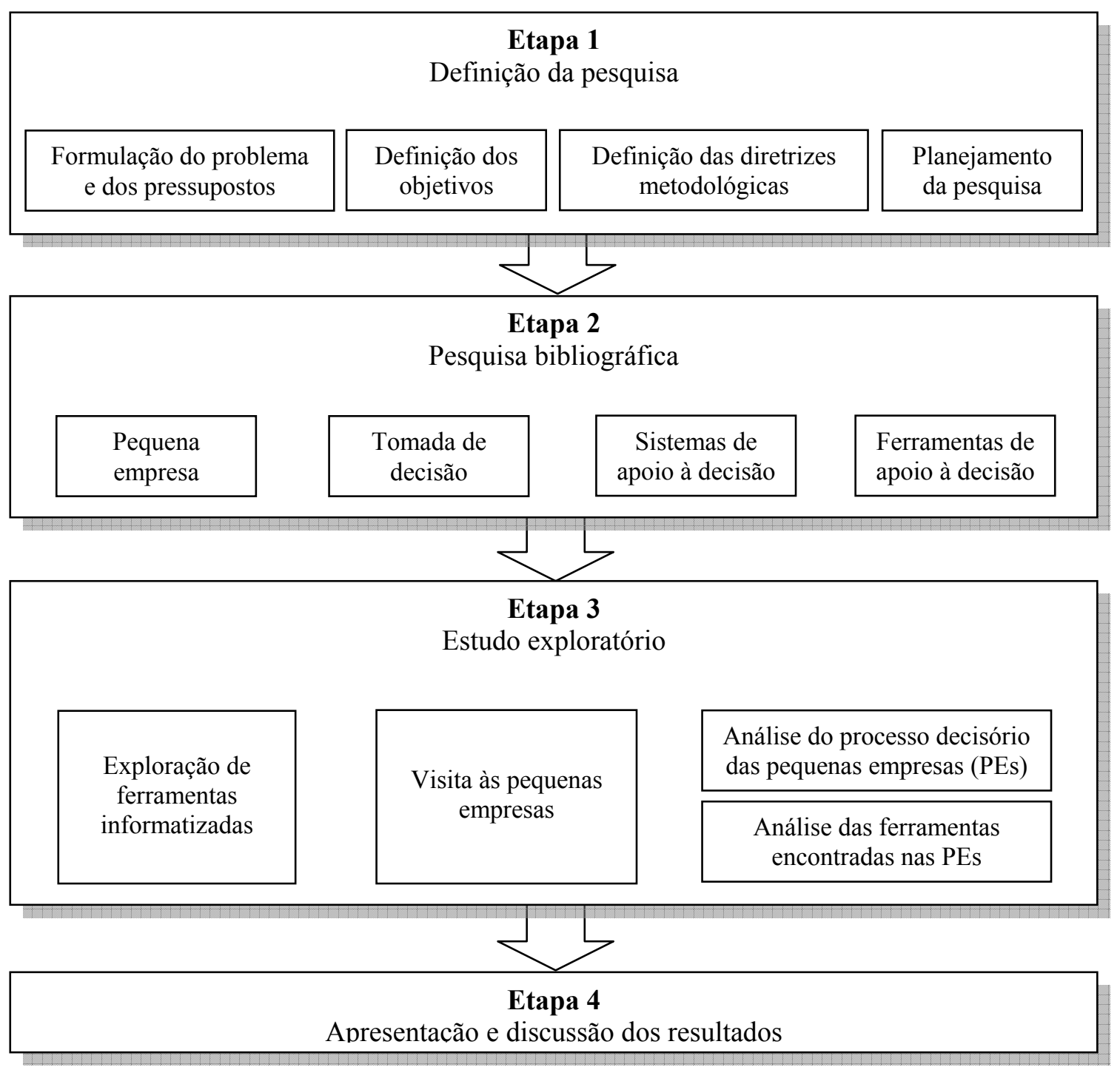

Figura 1 - Organização do trabalho. 


\section{CAPÍTULO 2 - REVISÃO BIBLIOGRÁFICA}

\subsection{CONSIDERAÇÕES INICIAIS}

Neste capítulo é apresentada a revisão bibliográfica referente ao tema e aos fatores qualitativos desta pesquisa, buscando embasar a reflexão e fornecer subsídios para a pesquisa de campo.

Em primeiro lugar, na seção 2.2 , são estudados a pequena empresa e os principais tópicos inerentes a ela, ou seja, os critérios para sua definição, a sua importância para o cenário sócio-econômico brasileiro, os principais motivos relacionados à sua sobrevivência e mortalidade, bem como as suas particularidades de gestão. Além disso, é explorada a amplitude da tecnologia da informação em seu ambiente organizacional de maneira a contextualizar e preparar o trabalho para abordar os próximos assuntos.

Na seqüência, na seção 2.3, são abordados os principais tópicos relacionados à tomada de decisão nas empresas, ou seja, os principais tipos e métodos de decisão, as etapas do processo decisório e a importância da tomada de decisão na gestão das empresas. Encerra-se esta seção, analisando o processo decisório na pequena empresa, destacando suas características peculiares, de modo a fornecer informações para se confrontar, na pesquisa de campo, a utilização de ferramentas computacionais para apoiar as decisões nestas empresas.

Encerrando este capítulo, são estudados os sistemas de apoio à decisão, seu conceito, as principais diferenças entre os sistemas de informações transacionais e os sistemas de apoio à decisão, algumas características e os principais usos desses sistemas.

É importante destacar que devido ao caráter exploratório desta pesquisa, e ao delineamento metodológico adotado ser o estudo de caso, a revisão bibliográfica apresentada neste capítulo tem como objetivo fundamentar teoricamente o trabalho dentro do seu tema e de seus fatores qualificadores. Afinal, segundo Cervo e Bervian (2002, p. 72), a revisão bibliográfica pode ser encarada como "um estudo preliminar e 
sintético que trará informações sobre a situação atual do problema, sobre os trabalhos já realizados a respeito e sobre opiniões existentes".

\subsection{PEQUENA EMPRESA}

Ao longo do século passado, principalmente até meados da década de 80 , as grandes corporações prevaleceram como uma das únicas alternativas de impulsionar a economia dos países, tanto nos desenvolvidos como naqueles em desenvolvimento. Esse cenário foi provocado em grande parte pelo auge da industrialização dentro do modelo de produção em massa. Dessa maneira, as políticas governamentais durante esse período tenderam a favorecer as grandes unidades de fabricação e os conglomerados multinacionais (TERENCE, 2002).

Entretanto, ao analisar as informações do Instituto Brasileiro de Geografia e Estatística (IBGE) e do SEBRAE, nota-se nos últimos quinze anos um aumento significativo no número de pequenas empresas, sobretudo no Brasil.

Para Longenecker, Moore e Petty (1997), as pequenas empresas nascem na maioria das vezes do espírito empreendedor de uma ou mais pessoas. Os empreendedores são incentivados a abrir seus próprios negócios atraídos por possibilidades de recompensas. Essas recompensas são expressas basicamente através das possibilidades de ganhos financeiros - lucros, autonomia para trabalhar e pela busca de um estilo de vida prazeroso aliado à liberdade, satisfação e fuga da monotonia.

Segundo Zamarioli (2003), não se consegue afirmar com exatidão quais os motivos do crescimento do número de pequenas empresas, sendo possível, de acordo com o autor, apenas supor algumas prováveis causas. São elas:

- $\quad$ A dificuldade de controle por parte das grandes corporações;

- $\quad \mathrm{O}$ excesso de encargos sociais que recaem sobre as grandes empresas, facilitando a terceirização de seus setores não essenciais; ou,

- $\quad$ A somatória de todos esses fatores aliados à flexibilidade que a pequena empresa tem para driblar as dificuldades e encontrar novos caminhos num curto espaço de tempo.

Complementando os prováveis motivos apontados por Zamarioli (2003), Longenecker, Moore e Petty (1997) consideram que os fatores abaixo relacionados podem estar contribuindo para o crescimento do número de pequenas empresas: 
- Novas tecnologias, como as máquinas e ferramentas controladas numericamente podem permitir uma produção eficiente em menor escala;

Maior flexibilidade por parte das empresas para se manterem competitivas globalmente, um requisito que favorece as de pequeno porte;

- $\quad$ As pequenas empresas podem ser mais flexíveis, empregando o número crescente de mulheres que integram a força de trabalho;

- A busca, por parte dos consumidores, de produtos personalizados em detrimento aos bens produzidos em massa, criando, desse modo, oportunidades para as empresas menores.

Diante do crescimento do número de pequenas empresas, do aumento das oportunidades de empregos e geração de renda que são proporcionados por elas, e por outro lado, da constatação do seu alto índice de encerramento precoce, tem crescido a preocupação dos pesquisadores em entender os problemas enfrentados por essas empresas levando-se em consideração as suas particularidades (ALBUQUERQUE, 2004; BIGATON, 2005; CARVALHO, 2004; DUARTE, 2004; MIGLIATO, 2004; OSTANEL, 2005; TERENCE, 2002; ZAMARIOLI, 2003). Essa preocupação, traduzida na forma de inúmeros estudos, busca oferecer ao dirigente da pequena empresa, segundo Leone (1999, p. 91), os "conhecimentos que necessitam e que lhes permitam administrar a empresa o mais eficazmente possível, em um ambiente econômico em constante evolução".

Corroborando com essa preocupação, o presente trabalho foi motivado e proposto, a analisa nas próximas seções o ambiente das pequenas empresas, destacando, entre outros aspectos, seus vários critérios de definição, suas peculiaridades de gestão e sua importância para o cenário sócio-econômico brasileiro.

\subsubsection{Critérios para definição de pequena empresa}

De acordo com Terence (2002),

o tamanho não modifica a natureza de uma empresa ou os princípios de sua administração, não altera os problemas básicos dos administradores e, ainda, não afeta a administração do trabalho e do trabalhador. Mas, o tamanho afeta a estrutura administrativa, pois cada tamanho exige um comportamento e uma atitude diferente dos órgãos administrativos. (DRUCKER, 1981).

A definição de pequena empresa com base em padrões de tamanho é algo necessariamente complexo e arbitrário, pois de acordo com o propósito os padrões são 
estabelecidos. Por exemplo, para fins legislativos, as pequenas empresas podem ser definidas de acordo com o número de empregados e para outros fins de acordo com o volume faturado, valor dos ativos e volume de depósitos (LONGENECKER, MOORE e PETTY, 1997).

A classificação das empresas é um assunto problemático para os pesquisadores, em função da heterogeneidade de critérios existentes, do tamanho das empresas e das suas condições econômicas e produtivas. Desse modo, esta subseção não visa analisar os diversos critérios de classificação existentes, mas apenas discutir os mais relevantes e os mais discutidos entre os pesquisadores de pequenas empresas, apresentando, ao final, a classificação a ser utilizada neste trabalho.

Na maioria das vezes, os critérios utilizados para definir o tamanho de uma empresa são de ordem qualitativa ou quantitativa. O Quadro 1, abaixo, foi elaborado a partir das considerações de Albuquerque (2004), Duarte (2004) e Terence (2002), e tem como objetivo resumir os principais aspectos adotados pelos critérios qualitativos e quantitativos de classificação de empresas.

\begin{tabular}{|c|c|c|}
\hline $\begin{array}{l}\text { Critérios de } \\
\text { classificação }\end{array}$ & Aspectos adotados & Vantagens \\
\hline \multirow{6}{*}{ Qualitativos } & Tecnologia utilizada. & \multirow{6}{*}{$\begin{array}{c}\text { Apresenta com maior } \\
\text { veracidade a natureza da } \\
\text { empresa. }\end{array}$} \\
\hline & Estrutura da organização. & \\
\hline & Nível de especialização da mão-de-obra. & \\
\hline & Relacionamento entre administrador e empregados. & \\
\hline & Tipos de máquinas e ferramentas. & \\
\hline & Utilização de técnicas de administração. & \\
\hline \multirow{8}{*}{ Quantitativos } & Faturamento bruto anual. & \multirow{8}{*}{$\begin{array}{l}\text { Facilidade na coleta das } \\
\text { informações. }\end{array}$} \\
\hline & Número de empregados. & \\
\hline & Volume de salários. & \\
\hline & Capital social. & \\
\hline & Lucro. & \\
\hline & Patrimônio líquido. & \\
\hline & Produtividade. & \\
\hline & Participação no mercado. & \\
\hline \multirow{4}{*}{ Mistos } & Natureza artesanal da atividade. & \multirow{4}{*}{$\begin{array}{l}\text { Possibilidade de combinação } \\
\text { de indicadores econômicos } \\
\text { com características sociais e } \\
\text { políticas. }\end{array}$} \\
\hline & Predominância do trabalho próprio e de familiares. & \\
\hline & Capital empregado. & \\
\hline & Renda bruta anual. & \\
\hline
\end{tabular}

Quadro 1 - Critérios de classificação de empresas.

Fonte: elaboração própria a partir de Albuquerque (2004), Duarte (2004) e Terence (2002).

Segundo Pinheiro (1996), a pequena empresa se define por uma série de características qualitativas ou circunstâncias relacionadas às suas particularidades. $\mathrm{O}$ autor argumenta que as características da pequena empresa estão, na maioria das vezes, delimitadas pelos seguintes fatores ou condições: 
- A empresa é de propriedade de um só indivíduo ou pequeno grupo de pessoas;

- Ela é administrada pelos proprietários de forma independente e, mesmo quando profissionalizada, eles se conservam como o principal centro das decisões;

- O seu capital é financiado, basicamente, pelos proprietários;

- $\quad$ Ela atua numa área limitada, geralmente, restrita à sua localização ou no máximo à região onde está situada;

- A sua atividade produtiva não ocupa lugar de destaque ou de predominância no mercado onde atua.

No entanto, de acordo com Leone (1991), deve-se considerar a dificuldade da classificação qualitativa. Na opinião da autora, são os critérios quantitativos que predominam. A classificação por tamanho, além de revelar o comportamento econômico e social significativo das PMEs, pode apontar soluções mais adequadas aos seus problemas, servindo inclusive de parâmetro aos programas e ações de governo (ALBUQUERQUE, 2004).

Nos Estados Unidos, a Small Business Administration (SBA), uma agência federal semelhante ao SEBRAE, a qual tem como objetivo ajudar, aconselhar e proteger os interesses da pequena empresa norte-americana estabelece padrões através dos quais o tamanho das empresas pode ser medido. Esses padrões são utilizados de acordo com o segmento das empresas e baseiam-se no número de empregados e no volume anual de vendas para classificá-las (SBA, 2004).

No Brasil, vários critérios são adotados por diferentes instituições públicas e privadas. Segundo o SEBRAE, a adoção de critérios para a definição do tamanho de um negócio constitui importante fator de apoio às micro e pequenas empresas (MPEs), pois permite àquelas classificadas dentro dos limites estabelecidos, usufruírem benefícios e incentivos previstos nas legislações que dispõem sobre o tratamento diferenciado ao segmento (SEBRAE, 2004b). Deste modo, de acordo com o SEBRAE (2004b), a definição das empresas com base no tamanho, tende a incentivar e aumentar as exportações, a geração de emprego e de renda, contribuindo para a diminuição da informalidade dos pequenos negócios.

Em 1999 o Estatuto das MPEs, reformulado pela lei n. ${ }^{0}$ 9.841/99, estabeleceu as diretrizes para classificação dos pequenos negócios. Esses critérios são adotados pelo governo federal e pela maioria dos estados brasileiros (exceto aqueles que ajustam os valores às suas realidades) e leva em consideração a receita bruta anual. Os critérios 
adotados pelo Estatuto das MPEs, e utilizados atualmente no Brasil, são apresentados no Quadro 2, abaixo:

\begin{tabular}{|c|c|}
\hline Classificação & Receita bruta anual \\
\hline Microempresa & Igual ou inferior a R \$ 433.755,14. \\
\hline Pequena empresa & Entre R $\$ 433.755,14$ e $\mathrm{R} \$ 2.133 .222,00$. \\
\hline
\end{tabular}

Quadro 2 - Definição de pequena empresa de acordo com o Estatuto das MPEs.

Fonte: elaboração própria a partir de dados do SEBRAE (2004b).

O SEBRAE adota o mesmo critério que o IBGE, o qual classifica as empresas de acordo com o número de empregados combinado com o setor produtivo que atuam. Essa classificação, utilizada atualmente no Brasil, em conjunto com a classificação por volume faturado, é exibida no Quadro 3, abaixo:

\begin{tabular}{|c|c|c|}
\hline Classificação & Setor produtivo & Número de empregados \\
\hline \multirow{2}{*}{ Microempresa } & Indústria & Até 19 \\
\cline { 2 - 3 } & Comércio e serviços & Até 09 \\
\hline \multirow{2}{*}{ Pequena empresa } & Indústria & De 20 a 99 \\
\cline { 2 - 3 } & Comércio e serviços & De 10 a 49 \\
\hline \multirow{2}{*}{ Empresa de médio porte } & Indústria & De 100 a 499 \\
\cline { 2 - 3 } & Comércio e serviços & Acima de 500 \\
\hline Grande empresa & Indústria & Acima de 100 \\
\cline { 2 - 3 } & Comércio e serviços & \\
\hline
\end{tabular}

Quadro 3 - Classificação das empresas de acordo com o SEBRAE.

Fonte: elaboração própria a partir de dados do SEBRAE (2004b).

O que pode ser observado através dos diversos trabalhos publicados sobre definição de pequena empresa, é que não existe um consenso sobre qual o melhor critério a ser utilizado. Portanto, cabe ao usuário da informação escolher o critério que melhor se ajustar aos seus objetivos (LEONE, 1991; LONGENECKER, MOORE e PETTY, 1997).

Dessa maneira, o presente trabalho adotará o mesmo critério utilizado pelo SEBRAE e pelo IBGE, que tem como base o número de funcionários e o setor de atuação da empresa.

\subsubsection{Importância da pequena empresa no cenário sócio-econômico brasileiro}

De acordo com os dados do IBGE, existem no Brasil cerca de 3,5 milhões de empresas, das quais $98 \%$ são de micro e pequeno porte. Com base nos dados disponíveis da Pesquisa Nacional por Amostra de Domicílios (PNAD) do IBGE e na Relação Anual de Informações sociais (RAIS) do Ministério do Trabalho e Emprego 
(MTE), é possível afirmar que as atividades típicas das micro e pequenas empresas mantêm cerca de 35 milhões de pessoas ocupadas em todo o país. Esse número equivale a 59\% das pessoas ocupadas no Brasil (DUARTE, 2004).

Diante desse quadro pode-se assegurar que as pequenas empresas contribuem sobremaneira para a economia do país como um todo. Além do aspecto da empregabilidade, apontado nos números acima, elas oferecem contribuições excepcionais na medida em que fornecem novos empregos, introduzem inovações, estimulam a competitividade, auxiliam na rede de distribuição e na cadeia de suprimentos das grandes empresas (LONGENECKER, MOORE e PETTY, 1997).

Cardozo (2003), atual presidente da Ernest \& Young do Brasil, considera que as pequenas empresas são fortes aliadas na condução do Brasil rumo ao desenvolvimento.

\begin{abstract}
São essas pequenas companhias que apresentam dinamismo necessário para se adaptarem às mudanças bruscas de rumo. [...] São essas empresas que podem auxiliar na construção de um país moderno e plenamente integrado à globalização. Essa capacidade traduz-se em força competitiva, e é disso que o Brasil mais necessita. (CARDOZO, 2003, p. b7).
\end{abstract}

As empresas de pequeno porte exercem um papel importantíssimo para a sociedade brasileira, pois operam em praticamente todos os setores da economia, representando $48 \%$ da produção nacional e 20\% do PIB (MELO, 2001). Além disso, respondem por aproximadamente $60 \%$ da taxa de emprego, sendo um segmento ativo na formação da opinião pública e de mercado (ARGUELLO, 2002).

Terence (2001) destaca a relevância das pequenas empresas no cenário sócioeconômico brasileiro devido ao seu papel na promoção social, estabilidade política e propulsão de desenvolvimento, gerando empregos e incorporando tecnologias. Souza (1995) acrescenta outras justificativas para a relevância das pequenas empresas. Entre elas estão:

O estímulo à livre iniciativa e à capacidade empreendedora, relações capital/trabalho mais harmoniosas, efeito amortecedor dos impactos do desemprego e das flutuações na atividade econômica, manutenção de certo nível de atividade econômica em determinadas regiões, contribuição para a descentralização da atividade econômica, em especial na complementação às grandes empresas, potencial de assimilação, adaptação, introdução e, algumas vezes, geração de novas tecnologias de produto e de processo. (BENZE, CÊRA e ESCRIVÃO FILHO, 2003, p. 2-3). 
Como o propósito de resumir e destacar a importância sócio-econômica das MPEs, foi elaborada a Tabela 1, abaixo, com base em Albuquerque (2004) e Duarte (2004).

Tabela 1 - Importância sócio-econômica das MPEs.

\begin{tabular}{cc}
\hline Variável & Porcentagem \\
\hline Número de empresas & $98 \%$ \\
\hline Pessoal ocupado & $59 \%$ \\
\hline Empregos com carteira assinada & $50 \%$ \\
\hline Empregos informais & $100 \%$ \\
\hline Participação no PIB & $20 \%$ \\
\hline Participação nas exportações & $2 \%$ \\
\hline
\end{tabular}

Fonte: elaboração própria a partir de ALBUQUERQUE (2004) e DUARTE (2004).

\subsubsection{Sobrevivência e mortalidade da pequena empresa}

O SEBRAE estima que anualmente no Brasil, aproximadamente 500 mil empreendedores montam o seu próprio negócio. Entretanto, sete em cada dez empresas encerram suas atividades antes de completarem o quinto ano (SEBRAE, 2003a). A Tabela 2, abaixo, exemplifica esse quadro no tocante ao estado de São Paulo.

Tabela 2 - Taxa de mortalidade das MPEs.

\begin{tabular}{cc}
\hline Período de existência & Taxa de mortalidade \\
\hline Até o $1^{\circ}$ ano & $32 \%$ \\
\hline Até o $2^{\circ}$ ano & $44 \%$ \\
\hline Até o $3^{\circ}$ ano & $56 \%$ \\
\hline Até o $4^{\circ}$ ano & $63 \%$ \\
\hline Até o $5^{\circ}$ ano & $71 \%$ \\
\hline
\end{tabular}

Fonte: DUARTE (2004).

De acordo com SEBRAE (2003a), os principais motivos, na visão dos empresários, do fechamento de seus negócios são em ordem decrescente:

- $\quad$ Falta de demanda;

- Crédito e capital de giro;

- $\quad$ Problemas pessoais;

- Inadimplência dos clientes;

- Impostos e encargos tributários;

- $\quad$ Problemas entre os sócios;

- Concorrência;

- Custos elevados;

- Crises econômicas; 
Segundo as conclusões do SEBRAE, esse cenário de alta mortalidade é causado em função de vários fatores, entre eles, as dificuldades financeiras, o pequeno conhecimento do mercado, a falta de visão do futuro, o improviso do planejamento e o descuido com o gerenciamento.

A pequena empresa que consegue firmar-se além dos cinco primeiros anos depara-se muitas vezes com problemas organizacionais decorrentes do crescimento sem planejamento. A influência da incerteza nos aspectos internos sobre as estruturas organizacionais afeta o comportamento estratégico das pequenas empresas. $\mathrm{O}$ ambiente externo obriga o dirigente da pequena empresa a adotar uma postura centralizadora de administrar o negócio, preferindo agir por conta própria guiado mais pela sua sensibilidade do que pelos meios técnicos de administração (LEONE, 1999). Nas pequenas empresas,

\footnotetext{
os processos de planejamento e de controle são, geralmente pouco formalizados e quantificados. A escolha do melhor método de planejamento depende de variáveis como o estilo de direção, as capacidades dos responsáveis e a complexidade da atividade. (LEONE, 1999, p. 92).
}

Aliado a esses fatores, as pequenas empresas, devido às particularidades como são administradas, têm grandes dificuldades com relação à utilização eficiente das informações disponíveis em seu ambiente. Isso ocorre, geralmente, em função da falta de ferramentas capazes de organizar os dados existentes nessas empresas em informações que agreguem valor e subsidiem os seus processos de tomada de decisão (MIGLIOLI, OSTANEL e TACHIBANA, 2004).

Corroborando com Carvalho (2004), entende-se que a compreensão das características peculiares à pequena empresa pode trazer melhor entendimento de como as técnicas administrativas podem ser adequadas à pequena empresa visando ao seu desenvolvimento e sobrevivência.

\subsubsection{Particularidades na gestão da pequena empresa}

Durante muito tempo, acreditou-se que a gestão da pequena empresa deveria ser semelhante a das grandes corporações, pois dominava o paradigma da "pequena grande 
empresa", a qual seria uma empresa grande que ainda não havia crescido (WELSH e WHITE ${ }^{4}, 1981$ apud BENZE, CÊRA e ESCRIVÃO FILHO, 2003).

No entanto, atualmente diversos autores defendem a necessidade de se estudar a gestão das pequenas empresas sob outro enfoque, em função de possuírem algumas características específicas que as distinguem das de grande porte (ALBUQUERQUE, 2004; BENZE, CÊRA e ESCRIVÃO FILHO, 2003; LEONE, 1999; LONGENECKER, MOORE e PETTY, 1997; TERENCE, 2002).

Cêra e Escrivão Filho (2003) e Benze, Cêra e Escrivão Filho (2003), analisam e discutem em seus trabalhos, três grandes conjuntos de condicionantes que podem ser apontados como os causadores de algumas particularidades existentes na pequena empresa. Os condicionantes discutidos por esses autores são, resumidamente, de ordem:

Ambiental ou contextual: são as forças contextuais, ou seja, oriundas do ambiente externo às empresas e que estabelecem para a pequena empresa uma série de restrições e imposições. Segundo os autores essas imposições vão desde a exigência por produtos e serviços de alta qualidade, à escassez do capital ou tecnologia até a proibição pelos regulamentos governamentais. Esses fatores são responsáveis por algumas particularidades existentes na pequena empresa, entre elas, a concorrência desleal imposta pelas grandes empresas, o grande poder de barganha de clientes e fornecedores, a pequena ou nenhuma representatividade perante as imposições do macro-ambiente;

- $\quad$ Organizacional ou estrutural: representada pela estrutura organizacional não formalizada, rudimentar e reduzida, demonstrando uma alta fragilidade estrutural. Esses fatores contribuem para algumas particularidades encontradas na pequena empresa, entre elas, a estrutura organizacional informal, o baixo nível de especialização e a centralização;

Comportamental: diz respeito à maneira pela qual os empresários se comportam frente à gestão de suas empresas. As ações do pequeno empresário, geralmente são orientadas pela tradição (o empresário confia na manutenção dos costumes), pela ação afetiva (muito presente nas relações familiares e de amizade presentes na pequena empresa) e pela ação racional (os pequenos empresários acreditam que podem agir de acordo com sua própria racionalidade). Esses fatores contribuem para particularidades como a não utilização de instrumentos administrativos formais; informalidade no relacionamento e falta de habilidade na gestão do tempo, uma vez que

\footnotetext{
${ }^{4}$ WELSH, J. A.; WHITE, J. F. (1981). A small business is not a little big business. Harvard Business Review. V. 59, n. 4, p. 18-32, jul/aug.
} 
o pequeno empresário, geralmente, envolve-se mais com questões operacionais do que estratégicas.

Benze, Cêra e Escrivão Filho (2003), destacam que as particularidades das pequenas empresas não atuam de forma isolada, mas sim se influenciam mutuamente. Os autores elaboraram a Figura 2, abaixo, como forma de esquematizar resumidamente as principais especificidades presentes nas pequenas empresas.

Especificidades organizacionais ou estruturais

- Estrutura organizacional informal;

- Baixo nível de especialização;

- Estrutura organizacional reduzida;

- Centralização.

\section{Especificidades comportamentais}

- Ausência de instrumentos administrativos formais;

- Informalidade no relacionamento;

- Falta de habilidade na gestão do tempo.

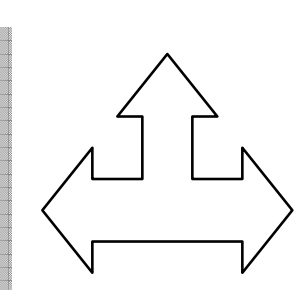

\section{Especificidades ambientais ou} contextuais

- Concorrência desigual com as grandes empresas;

- Clientes e fornecedores com maior poder de barganha;

- Pouco ou nenhum poder de influência no macroambiente.

Figura 2 - Inter-relação entre as especificidades das pequenas empresas.

Fonte: BENZE, CÊRA e ESCRIVÃO FILHO (2003).

Leone (1999) aponta outras características particulares das pequenas empresas, e as organiza em três grupos, conforme a seguir:

Especificidades organizacionais: pobreza de recursos, gestão centralizada, situação extra-organizacional incontrolável, fraca maturidade organizacional, estrutura simples e leve, ausências de atividade de planejamento formal, estratégia intuitiva e pouco formalizada, sistemas de informações simples;

- Especificidades decisionais: tomada de decisões intuitivas, horizonte temporal de curto prazo, inexistência de dados quantitativos, alto grau de autonomia decisional, racionalidade econômica, política e familiar;

Especificidades individuais: onipotência do proprietário-dirigente, identidade entre pessoa física e jurídica, dependência de certos empregados, influência pessoal do proprietário-dirigente, simbiose entre patrimônio social e patrimônio pessoal, propriedade dos capitais, propensão a riscos calculados. 
Essas especificidades, ou simplesmente, particularidades no modelo de gestão das pequenas empresas, explica em parte, o que Leone (1999) quis dizer com relação aos processos de planejamento e controle pouco formalizados e quantificados presentes nessas empresas, onde "a escolha do melhor método de planejamento depende de variáveis como o estilo de direção, as capacidades dos responsáveis e a complexidade da atividade" (LEONE, p. 92). Esse improviso na tomada de decisões e na formulação de estratégias pode ser considerado como um dos motivos pelos quais muitas pequenas empresas brasileiras perdem espaços e oportunidades de mercado, ou mesmo encerram suas atividades antes de completarem o quinto ano (PEGN, 2002).

\subsubsection{Tecnologia da informação na pequena empresa}

De acordo com O’Brien (2003), a tecnologia da informação é a infra-estrutura organizada através de hardware, software, rede, banco de dados e outras tecnologias utilizadas no processamento da informação. Desta maneira, pode-se afirmar que a tecnologia da informação deve proporcionar as condições necessárias para que as empresas possam:

- Capturar os dados presentes em seus ambientes (interno e/ou externo);

- $\quad$ Processar e transformar esses dados em informações relevantes;

- Armazenar e disseminar essas informações ao longo dos seus níveis organizacionais (operacional, tático e estratégico).

Conforme destaca $\operatorname{Earl}^{5}$ (1990 apud BERALDI e ESCRIVÃO FILHO, 2001), a tecnologia da informação apresenta-se como uma poderosa ferramenta no atual contexto globalizado, podendo aumentar a vantagem competitiva, sobretudo na pequena empresa.

Para Doukidis, Lybereas e Galliers (1996), algumas vantagens podem ser identificadas pelo uso da tecnologia da informação nas pequenas empresas. Beraldi, Escrivão Filho e Rodrigues (2000), exemplificam essas vantagens da seguinte maneira:

- Melhoria das informações para a tomada de decisão;

- $\quad$ Automação de tarefas rotineiras;

- Melhoria do controle interno das operações;

- Melhoria no atendimento ao cliente;

- $\quad$ Aumento na capacidade de reconhecer precocemente os problemas;

- Auxílio ao gerente para testar algumas decisões antes de implementá-las;

\footnotetext{
${ }^{5}$ EARL, M. (1990). Information management. Oxford: Clarendon Press.
} 
- $\quad$ Melhoria do processo produtivo;

- $\quad$ Aumento da produtividade e competitividade;

- Possibilidade de novas formas organizacionais, tais como redes de empresas;

- $\quad$ Possibilidade de se redefinir o negócio;

- $\quad$ Melhoria na percepção gerencial;

- $\quad$ Maior valor agregado aos produtos e serviços.

Entretanto, segundo Beraldi e Escrivão Filho (2001), a maioria das pequenas empresas não sente os efeitos positivos na informatização, demonstrando que a tecnologia da informação ainda não está a serviço dos negócios nessas empresas.

Alguns autores destacam que os motivos prováveis para este cenário são:

- Desvio de foco, ou seja, muitas dessas empresas não definem para qual propósito serão usados os equipamentos e sistemas antes de comprá-los (SANTOS, 1998);

- A limitação financeira dessas empresas (BERALDI E ESCRIVÃO FILHO, 2001).

Conscientes dessa limitação financeira, os grandes fornecedores de tecnologia da informação estão oferecendo produtos que atendam às necessidades e ao mesmo tempo sejam acessíveis financeiramente às empresas de pequeno porte, tais como:

- $\quad$ Redes de comunicação;

- $\quad$ Sistemas de gerenciamento de banco de dados;

- $\quad$ Planilhas eletrônicas;

- $\quad$ Sistemas de gestão empresarial (ERP);

- $\quad$ Sistemas de relacionamento com clientes (CRM);

- $\quad$ Sistemas de groupware.

Mas, mesmo com essas ofertas dos fornecedores de tecnologia da informação, o que se observa é um aumento no uso de aplicações relacionadas às funções operacionais e administrativas, persistindo uma grande carência por parte das pequenas empresas no que diz respeito às aplicações de apoio à decisão (PRATES e OSPINA, 2004). Essa carência muitas vezes é percebida pela falta de produtos para este propósito, ou mesmo, pela existência de produtos que estão fora da realidade e do ambiente organizacional específico destas empresas, as quais necessitam de soluções práticas, de fácil utilização e investimento moderado (MIGLIOLI, OSTANEL e TACHIBANA, 2004). 
Solomon $^{6}$ (1986) afirma que:

Uma dada tecnologia não é automaticamente boa ou má para a pequena empresa. Seu resultado dependerá da maneira como esta tecnologia será aplicada. Na verdade, o aumento da precisão organizacional, auxiliado por sistemas de informação, trará maior eficiência na administração de seus processos, recursos e atividades e maior eficácia na obtenção de resultados previamente estabelecidos. (PRATES e OSPINA, 2004, p. 12).

A amplitude da utilização da tecnologia da informação nas pequenas empresas paulistas pode ser observado através da pesquisa realizada pelo SEBRAE sobre a informatização das MPEs paulistas (SEBRAE, 2003b). De acordo com essa pesquisa, aproximadamente:

47\% das MPEs entrevistadas utilizam microcomputador e/ou notebook [...]. Esse percentual chega a $61 \%$ nas MPEs da indústria, $47 \%$ nos serviços e $43 \%$ no comércio. Com relação ao porte, $81 \%$ das empresas de pequeno porte e $40 \%$ das microempresas encontram-se informatizadas. Portanto, há uma clara diferença no grau de informatização entre setores e portes (SEBRAE, 2003b, p.5).

Diante desses dados, ao se analisar especificamente o universo das pequenas empresas (objeto de estudo desta pesquisa), nota-se um grau de informatização na ordem de $81 \%$ das empresas de pequeno porte (vide Gráfico 1, abaixo).

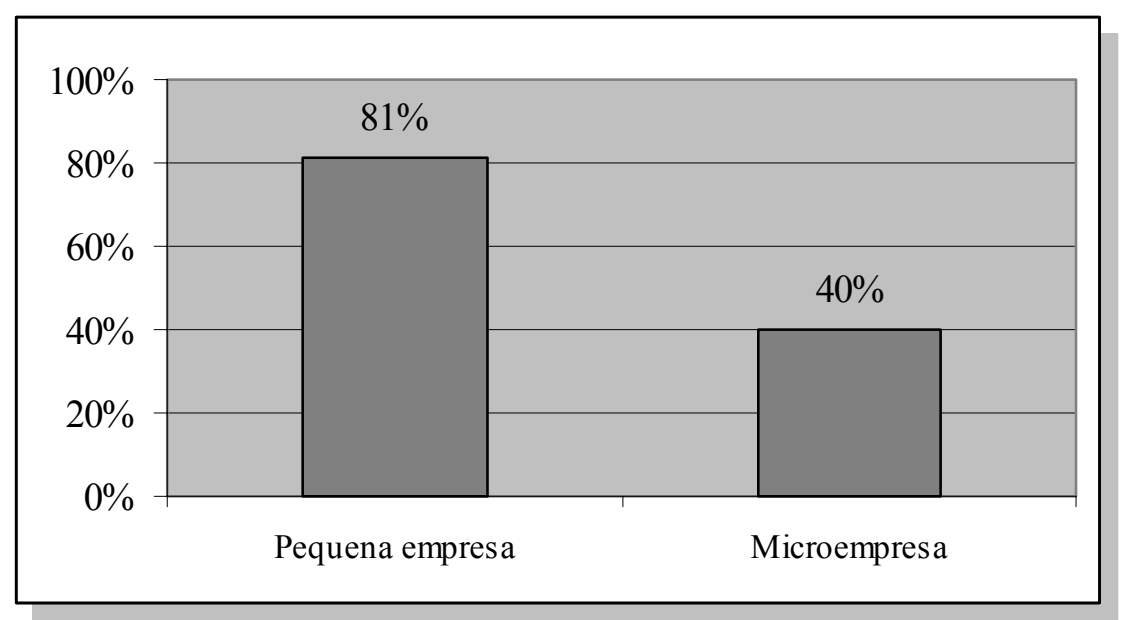

Gráfico 1 - Grau de informatização da pequena empresa paulista.

Fonte: elaboração própria a partir de dados do SEBRAE (2003b).

No entanto, ao se analisar as atividades em que o microcomputador é utilizado nas MPEs paulistas, percebe-se que o uso da tecnologia da informação nas tarefas

\footnotetext{
${ }^{6}$ SOLOMON, S. (1986). A grande importância da pequena empresa: a pequena empresa nos Estados
} Unidos, no Brasil e no mundo. Rio de Janeiro: Editorial Nórdica. 
operacionais é predominante em detrimento às atividades estratégicas e de apoio à decisão. Prova disso é que $81 \%$ das MPEs informatizadas utilizam seus microcomputadores para montar banco de dados de clientes (cadastro), 72\% para elaborar documentos, 66\% para acessar serviços na Internet, 56\% para controlar estoques, $51 \%$ para controlar folha de salários/pagamentos, $50 \%$ para mala-direta ( $\mathrm{fax}$ ou e-mail), 48\% para automação de processos e 36\% para emitir notas fiscais (SEBRAE, 2003b). Esses dados são exibidos no gráfico abaixo (Gráfico 2).

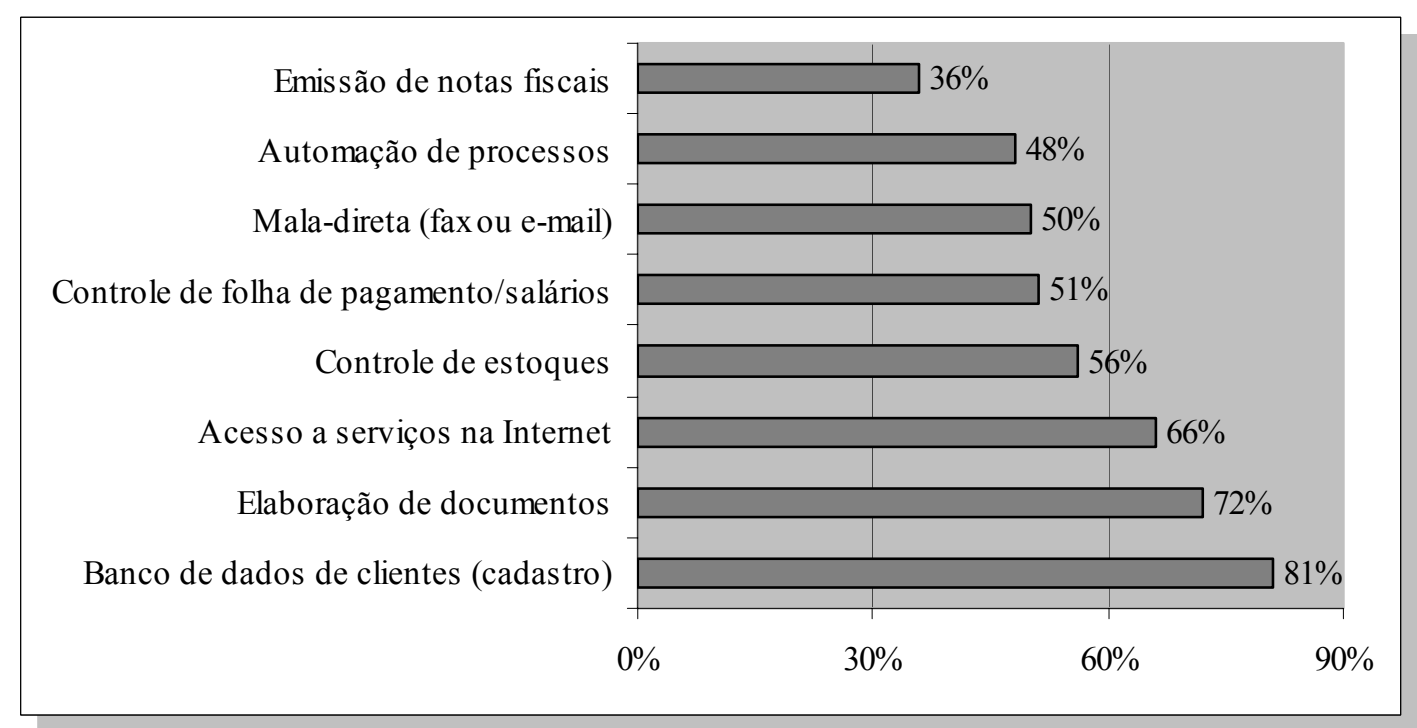

Gráfico 2 - Atividades em que o microcomputador é utilizado nas MPEs paulistas.

Fonte: relatório de pesquisa do SEBRAE (2003b).

O confronto da análise destes números com uma das principais conclusões desta pesquisa, destaca a importância do estudo das pequenas empresas no tocante à utilização e maximização dos seus recursos de tecnologia da informação no apoio à gestão empresarial. Daí, entre outras coisas, a motivação pelo tema do presente trabalho acadêmico.

Além disso, corroborando com Beraldi e Escrivão Filho (2001), acredita-se que a tecnologia da informação só atinge seu objetivo quando é vista como uma ferramenta que permite às empresas, mesmo às de pequeno porte, melhorar sua produtividade $\mathrm{e}$ competitividade através de um adequado tratamento e uso das informações.

\subsection{TOMADA DE DECISÃO}

$\mathrm{O}$ ato de tomar decisões faz parte de qualquer atividade humana, desde a mais simples e rotineira atividade individual, até o mais complexo projeto empreendido por 
uma grande organização. Para cada situação existem diferentes problemas envolvidos e diferentes graus de dificuldade para se tomar uma decisão.

Quanto maior for o número de alternativas, mais complexa se torna a tomada de decisão. Afinal, em um problema de decisão, seleciona-se uma alternativa de ação com a intenção de conseguir resultados ao menos tão satisfatórios quanto aquele que teria com qualquer outra opção disponível (DACORSO, 2000).

A tomada de decisão consiste na escolha de uma opção ou mais dentre diversas alternativas existentes, seguindo passos previamente estabelecidos a fim de culminar numa solução que resolva ou não o problema. De acordo com Zamarioli, Benze e Escrivão Filho (2003), é através de suas inúmeras tomadas de decisão e das respectivas ações que o executivo conduz a empresa.

Nas próximas seções são apresentados os principais aspectos relacionados à tomada de decisão. É importante ser destacado que não se pretende aqui aprofundar na ciência da decisão, tampouco, esgotar as discussões sobre esse assunto. O objetivo desta seção e de suas subseções é a compreensão do processo de tomada de decisão na pequena empresa, a fim de fornecer subsídios para se explorar as empresas do estudo de caso.

\subsubsection{Tipos e métodos principais de decisão}

Segundo Paiva (2002), o processo administrativo abrange quatro tipos principais de decisão, também chamados processos ou funções. São eles:

- Planejamento: consiste em tomar decisões sobre objetivos e recursos necessários para realizá-los;

- Organização: consiste em tomar decisões sobre a divisão de responsabilidade e autoridade entre pessoas e sobre a divisão de recursos para realizar tarefas e objetivos;

- Direção: compreende as decisões que acionam recursos, especialmente pessoas, para realizar tarefas e alcançar os objetivos;

- Controle: consiste em tomar decisões e agir para assegurar a realização dos objetivos.

Para Freitas e Kladis (1995), as decisões podem ser classificadas de acordo com o contexto onde ocorrem, segundo os diferentes níveis administrativos: 
- $\quad$ Estratégico: as decisões englobam a definição de objetivos, políticas e critérios gerais para planejar o curso da organização;

Tático: as decisões são normalmente relacionadas com o controle administrativo e utilizadas para decidir sobre operações de controle, formulação de novas regras de decisão que irão ser aplicadas por parte do pessoal da operação;

- Operacional: a decisão é um processo no qual se assegura que as atividades operacionais sejam bem desenvolvidas, utilizando-se procedimentos e regras de decisões preestabelecidas.

Com relação à maneira como as decisões são tomadas, Schermerhorn Júnior (1999) aponta três métodos que podem ocorrer dentro das empresas:

- Decisões individuais: pressupõe que o tomador tem informação e conhecimentos suficientes para tomar uma boa decisão;

- Decisões consultivas: o tomador de decisões busca informações e conselhos com outras pessoas sobre o problema, e com base nas informações colhidas e em sua interpretação, escolhe a alternativa que julga ser a melhor;

Decisões em grupo: o tomador pede ao grupo que tomem ou o ajudem a tomar a decisão final para a solução de determinado problema.

\title{
2.3.2 Etapas do processo decisório
}

Segundo Quelopana (2003),

\begin{abstract}
o processo decisório pode ser visto com uma seqüência de sensações, percepções e desejos, que deveria passar por uma ou mais decisões e prosseguir com a observação dos resultados das ações tomadas, numa ligação contínua com o próximo processo decisório, estágio em que nossa intuição estaria enriquecida com as experiências vivenciadas no processo decisório anterior. (QUELOPANA, 2003, p. 34).
\end{abstract}

Algumas decisões exigem análises detalhadas. Se a decisão é tão importante quanto complexa, então vale a pena analisá-la formalmente (QUELOPANA, 2003).

Corroborando com a idéia de uma análise formal, Bispo (1998) argumenta que as etapas do processo decisório devem seguir um modelo lógico e racional, ou seja:

- $\quad$ Identificação do problema;

- $\quad$ Levantamento das variáveis do problema;

- $\quad$ Elaboração de alternativas;

- $\quad$ Avaliação das alternativas obtidas (comparação); 
- $\quad$ Escolha da melhor alternativa ou da mais viável (decisão);

- Implementação da alternativa escolhida;

- Acompanhamento dos resultados;

- $\quad$ Análise do resultado;

- $\quad$ Extração das lições positivas ou negativas obtidas em todo o processo decisório;

- Avaliação da aplicação do modelo gerado para solucionar outros problemas iguais ou semelhantes.

Confirmando a opinião de Bispo (1998), Glautier e Underdown ${ }^{7}$ (1976 apud BEUREN, 2000) destacam que o processo de tomada de decisões pode ser visto como um encadeamento lógico de eventos, podendo ser analisado pelas seguintes fases:

- Reconhecimento da existência de um problema ou a necessidade de tomar uma decisão;

- $\quad$ Definição de todas as alternativas de solução para o problema;

- $\quad$ Coleta de todas as informações relevantes para as alternativas de solução;

- $\quad$ Avaliação e classificação do mérito das alternativas de solução;

- $\quad$ Decisão sobre a melhor alternativa de solução, selecionando a mais bem classificada;

- $\quad$ Validação da decisão por meio das informações de feedback.

Drucker (2001) propõe um processo decisório baseado numa seqüência de perguntas que devem ser respondidas no intuito de conseguir uma decisão eficaz:

- $\quad$ Esta é uma situação geral ou específica? - o que é geral sempre tem de ser solucionado com a formulação de uma regra, de um princípio. O específico só pode ser tratado como tal e quando ocorre;

- Quais são os objetivos que a decisão deve atingir? Quais são as metas mínimas que ela deve cumprir? Quais as condições que ela deve satisfazer? - uma decisão para ser eficaz precisa ser adequada à sua finalidade. Quanto maior a concisão e a clareza com que forem estabelecidas as condições, maior a probabilidade de que a decisão será eficaz e levará ao cumprimento dos objetivos;

O que é certo? O que é aceitável? - a solução que irá satisfazer plenamente as especificações antes de ser dada atenção aos compromissos, adaptações e concessões necessários para tornar a decisão aceitável;

${ }^{7}$ GLAUTIER, M. W. E; UNDERDOWN, B. (1976). Accounting: theory and practice. Londres: Pitman. 
- $\quad$ Como converter a decisão em ação? Quem precisa saber? Que medida deve ser tomada? E o que deverá ser feito para que as pessoas que precisam tomar a decisão tenham condições de concretizá-las? - nenhuma decisão se concretiza antes de alguém ter sido incumbido e responsabilizado por sua execução em etapas específicas. Até então, há apenas boas intenções;

As decisões obtiveram o resultado esperado? - a decisão deve incluir um feedback que possibilite um exame contínuo daquilo que se espera da decisão, diante dos acontecimentos reais.

Com o objetivo de resumir didaticamente as etapas do processo decisório discutidas anteriormente, apresenta-se a Figura 3, abaixo.

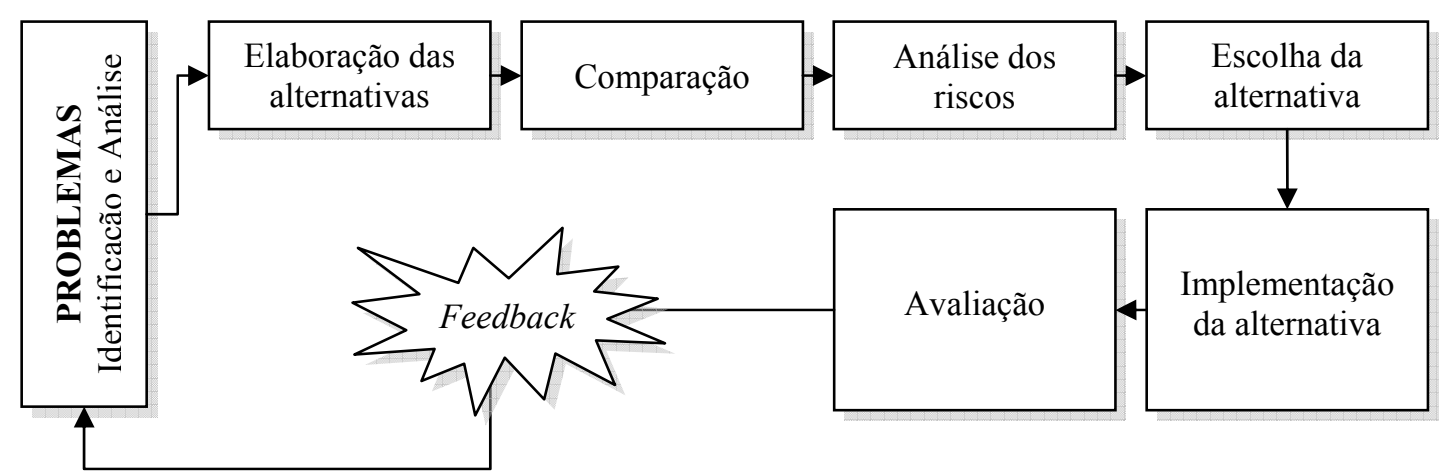

Figura 3 - Etapas do processo decisório.

Fonte: elaboração própria a partir de informação verbal ${ }^{8}$.

Cabe destacar que independentemente das etapas do processo decisório, a administração de qualquer empresa, principalmente as de pequeno porte, está diretamente relacionada à capacidade e habilidade de seus tomadores de decisão. A condução de uma empresa só é possível graças às inúmeras decisões tomadas por esses profissionais, os quais na pequena empresa, geralmente são os próprios donos da empresa, muitas vezes assessorados por seus familiares e/ou amigos (sócios).

\subsubsection{Importância da tomada de decisão para as empresas}

As decisões gerenciais afetam diretamente a sobrevivência das empresas e a vida daqueles que giram em torno dela, sejam eles empregados, acionistas, fornecedores, clientes ou, muitas vezes, a própria sociedade. Por isso, o processo decisório em uma

\footnotetext{
${ }^{8}$ Nota de aula fornecida pelo Prof. Dr. Edson Walmir Cazarini, através da disciplina de Sistemas de Apoio à Decisão, da Escola de Engenharia de São Carlos, da Universidade de São Paulo, em São Carlos, em março de 2004.
} 
empresa é algo importante não apenas para o seu ambiente interno. Prova disso, é a pressão que o tomador de decisão sofre, principalmente, de seus clientes.

De acordo com Bispo (1998), é necessário estabelecer prioridades, sobretudo, quando existem posições antagônicas entre os envolvidos na decisão (clientes versus acionistas versus empregados). Para o autor, as decisões são atos de poder, pois a partir do momento em que alocam recursos, definem estratégias, conduzem o destino de organizações e de pessoas, os tomadores de decisão assumem uma dimensão política muito semelhante à de um governo. No cotidiano, a viabilização desse processo, que na maioria das vezes é cheio de conflitos de interesses, exige objetivos compartilhados, liderança, comunicação efetiva e habilidade de negociação constante.

Diante deste quadro, para que os decisores tomem boas decisões, há a necessidade de que estas sejam baseadas em dados confiáveis que serão transformados nas variáveis do problema a ser solucionado e, posteriormente, indicarão as alternativas de solução do problema (OSTANEL, 2005). Quanto mais informações precisas e confiáveis o decisor tiver acesso, melhor poderá delinear o problema, suas alternativas e encontrar a melhor solução (BISPO, 1998).

\subsubsection{Processo decisório na pequena empresa}

Zamarioli, Benze e Escrivão Filho (2003), destacam alguns fatores que dificultam a administração e o processo decisório do executivo da pequena empresa:

- $\quad$ O pequeno porte das empresas;

- $\quad$ A falta de recursos financeiros para a contratação de profissionais e/ou serviços para suprir a falta de conhecimento administrativo;

- $\quad$ O excesso de atividades operacionais no dia-a-dia do dirigente, causando baixo, ou nenhum, planejamento estratégicos;

- $\quad$ Centralização do poder.

Além desses fatores, Nakamura e Escrivão Filho (1998), consideram que na pequena empresa a divulgação interna de metas e estratégias empresariais são prejudicadas em função da informalidade decorrente de detalhes imprecisos e da preferência por comunicações verbais. Na maioria dos casos, o pequeno empresário não especifica as estratégias adotadas pela empresa aos demais empregados, adotando um comportamento que ressalta a subjetividade e a intuição em detrimento da formalidade e racionalidade na gestão e tomada de decisões. 
Para Sauer e Colossi (1997), a falta de informações gerenciais e a concentração de responsabilidades e atribuições do pequeno empresário ocasionam um encadeamento de problemas e vícios na estrutura administrativa, que resultam em uma má administração, e conseqüentemente, na perda da sua competitividade.

Através de resultados obtidos em seu trabalho, Zamarioli, Benze e Escrivão Filho (2003), afirmam que os sistemas participativos garantem às empresas a influência de todos na participação das decisões, proporcionando assim, o fluxo vertical de idéias, desde o nível gerencial até o operacional.

Apesar disso, os autores constataram claramente que o processo de tomada de decisão nas pequenas empresas pesquisadas está centrado nas mãos do proprietário e obedece às particularidades presentes em cada empresa.

A participação do nível de direção nas empresas pesquisadas é exercida obedecendo às particularidades existentes em cada empresa, as quais expressam a visão de cada indivíduo (dono), de acordo com sua formação acadêmica, seus valores de vida, suas expectativas do negócio e da própria situação econômica que o país atravessa no momento. (ZAMARIOLI, BENZE e ESCRIVÃO FILHO, 2003, p. 12).

Os autores complementam afirmando que essa centralização na tomada de decisão na figura do diretor-proprietário, não significa que nada seja delegado ao nível gerencial. A este nível cabe decidir sobre as situações rotineiras, as quais já são de conhecimento do nível de direção e precisam ser tomadas no dia-a-dia dessas empresas.

Diante desta realidade, torna-se necessário explorar a relação dos principais tomadores de decisão das pequenas empresas (diretores-proprietários) com os possíveis sistemas ou ferramentas computacionais existentes em seus ambientes organizacionais.

\subsection{SISTEMAS DE APOIO À DECISÃO}

Desde o seu surgimento, os computadores vêm sendo utilizados para a realização de tarefas que de certa maneira automatizam muitas das operações do cotidiano das empresas, as quais são chamadas de transações. Durante as décadas de 60 e 70 as aplicações transacionais prevaleceram na indústria de sistemas informatizados, que se dedicavam exclusivamente à captação, armazenamento e recuperação dos dados originados das transações. Esses aplicativos não eram, de modo geral, utilizados para o fornecimento de informações que pudessem dar suporte ao processo de tomada de decisões em nível gerencial das empresas (VIOTTI e BRAGA, 1998). 
Segundo os autores, esse quadro começou a se modificar por volta de 1982,

quando os microcomputadores se tornaram acessíveis à grande maioria das empresas, seguidos das tecnologias de bancos de dados, de acesso distribuído, e com o aparecimento de aplicativos com interfaces que facilitavam seu uso por usuários casuais e leigos. Os usuários passaram a poder utilizar os computadores para ter acesso aos sistemas e dados transacionais da empresa, contando com aplicativos como planilhas eletrônicas, que permitiam a extração de dados e sua visualização de maneira conveniente. (VIOTTI e BRAGA, 1998, p. 1).

Os sistemas de informação foram ao longo dos anos sofrendo crescentes alterações em seus papéis e em suas funções. Essas funções, segundo O’Brien (2003), têm sido significativamente ampliadas ao longo das últimas décadas. A Figura 4, abaixo, resume algumas dessas mudanças.

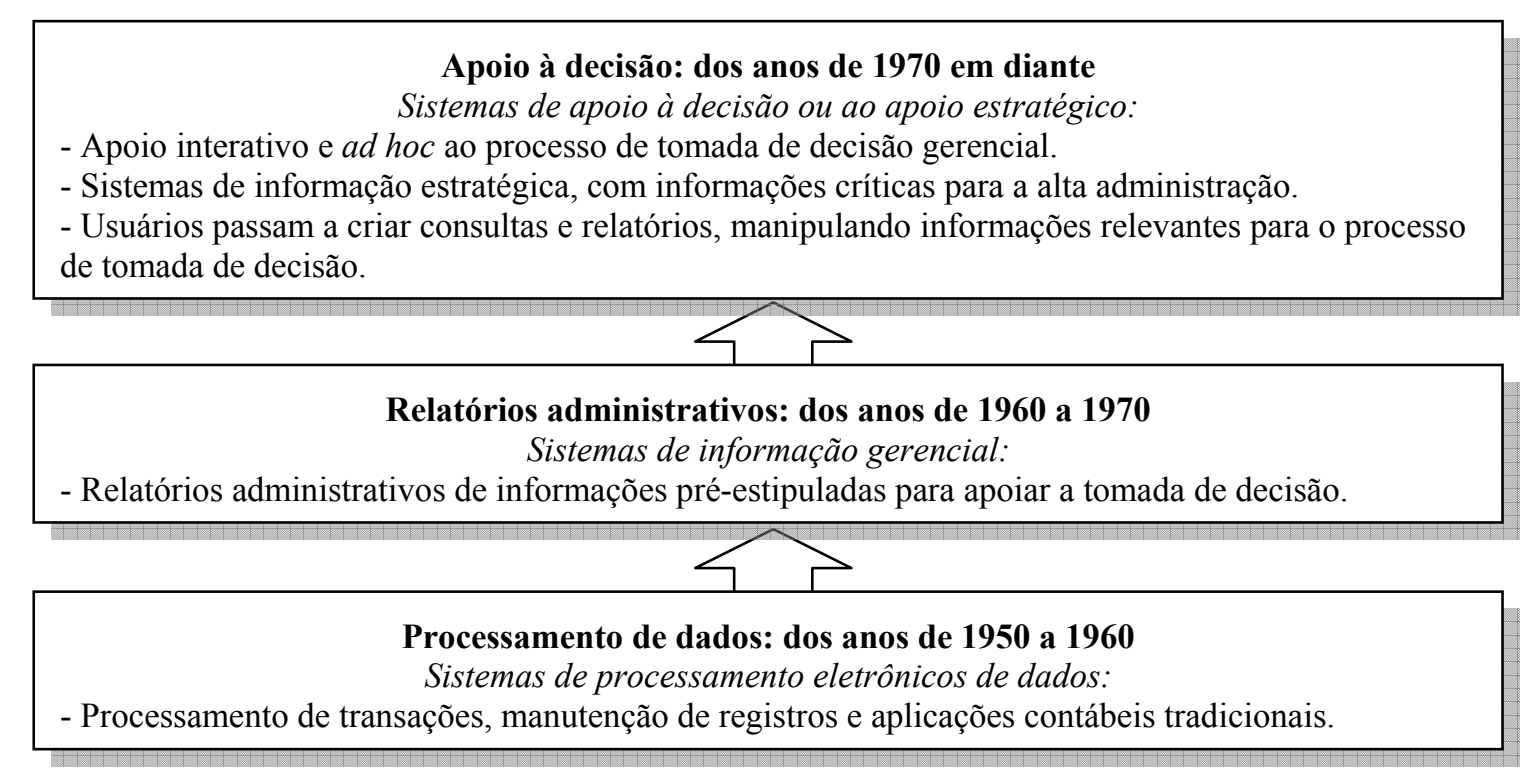

Figura 4 - A expansão das funções dos sistemas de informação.

Fonte: elaboração própria baseada em O’Brien (2003).

Segundo O'Brien (2003), os sistemas de informação até os anos 60 eram utilizados simplesmente para o processamento de transações, manutenção de registros, contabilidade e outros aplicativos de processamento eletrônico de dados. De acordo com o autor, alguns anos mais tarde, outro papel foi atribuído aos sistemas ao se elaborar o conceito de sistemas de informação gerencial (SIG). Esse novo papel se concentrava em fornecer aos usuários finais gerenciais relatórios predefinidos que tinham como objetivo equipar os gerentes com as informações necessárias para fins de tomada de decisão.

Entretanto, O’Brien (2003) destaca que a partir dos anos 70 os SIGs não estavam mais atendendo adequadamente às necessidades de tomada de decisão administrativa. 
Surgiu então o conceito de sistemas de apoio à decisão (SAD), o qual de acordo com Sprague Júnior e Watson (1991) originou a partir do trabalho de diversas empresas e grupos de pesquisas, que tinham como meta criar sistemas computacionais interativos que auxiliassem no processo decisório de problemas considerados não estruturados.

Viotti e Braga (1998) consideram que a partir da década de 90, começaram a surgir aplicativos para atender a um tipo de uso mais sofisticado, o qual necessitava de processamento analítico, a fim suprir às necessidades de informação para as tomadas de decisão gerencial em áreas críticas do negócio das empresas. Surgiu então, uma forte tendência em fornecer aos gerentes das empresas sistemas capazes de auxiliá-los em sua principal tarefa, ou seja, a tomada de decisão.

O que pode ser observado através da literatura existente sobre a evolução da tecnologia da informação e dos próprios sistemas de informação rumo ao surgimento dos SADs, é que até meados da década de 60 somente as grandes corporações podiam utilizar o computador. Foi a partir da década de 70, com o surgimento dos microprocessadores e da tecnologia de armazenamento e acesso a dados, que os microcomputadores passaram a ser vistos como poderosas máquinas de apoio aos negócios. Daí em diante, com a explosão e a popularização da microinformática em geral a partir das décadas de 80 e 90, a infra-estrutura necessária para a disseminação e evolução dos SADs estava pronta. A partir de então, ficou clara a diferença entre os objetivos dos SIGs (processamento de transações) e dos SADs (análise de negócios).

\subsubsection{Dados, informação e conhecimento}

Conforme discutido ao longo da seção 2.3, os executivos e/ou proprietários de empresas vivem da tomada de decisões, e o processo que envolve a ação gera inúmeras incertezas. Segundo Leme Filho (2004), a solução para isso é dispor do maior número de informações relevantes. Isso só é possível por intermédio da estruturação de um sistema de suporte à decisão.

De acordo com Miglioli, Ostanel e Tachibana (2004), o avanço da tecnologia da informação desenvolveu maneiras de melhor aproveitar os dados produzidos interna e externamente em uma empresa, organizando, classificando, armazenando, e o mais importante, atribuindo relevância a eles.

Os sistemas de apoio à decisão devem atender às necessidades do negócio, confrontando a expectativa de seus patrocinadores com as possibilidades de extração e 
captação de dados. A matéria-prima para esses sistemas são os dados, que transformados em informação permitem às pessoas usarem "suas massas encefálicas" para lapidar a informação em conhecimento (LEME FILHO, 2004, p. 10).

Tendo em vista a importância para os SADs dos dados e das informações, tornase necessário estabelecer a diferença entre eles e o processo de transformação de um para o outro elemento.

Pereira (2000) define informação como o resultado do processo de lapidação dos dados a fim de que tenham significado e relevância. E o conhecimento, que segundo Chiavenatto (2000) é o produto a ser gerado pela sociedade atual, é a informação estruturada que tem valor para a organização.

Para Colmanetti (2003), os dados representam a matéria-prima para a informação, cujo objetivo é alterar de alguma forma a percepção que uma pessoa tem sobre algo. A autora completa afirmando que "diferentemente dos dados, a informação tem um significado intrínseco, normalmente estando organizada para um determinado objetivo. Ela surge quando algum significado é adicionado aos dados". (COLMANETTI, 2003, p. 23).

Leme Filho (2004) define dados como os componentes básicos, a partir dos quais a informação é criada. Já informação são os dados com significado, inseridos num contexto. E o conhecimento é o elemento que orienta as pessoas no uso da informação para que possam executar suas atividades de trabalho.

\begin{tabular}{|c|c|c|}
\hline Elementos & Características & Exemplos \\
\hline \multirow{6}{*}{ Dados } & São simples observações sobre o estado do mundo. & \multirow{6}{*}{$\begin{array}{c}\text { Nota fiscal número 1.040 } \\
\text { emitida em 23.09.2003; foi } \\
\text { cancelada em 30.09.2003; } \\
\text { motivo: pedido entregue com } \\
\text { atraso. }\end{array}$} \\
\hline & Facilmente estruturado. & \\
\hline & Facilmente obtido por intermédio de sistemas. & \\
\hline & Freqüentemente quantificado. & \\
\hline & Facilmente transferível. & \\
\hline & Claro, apresentável & \\
\hline \multirow{6}{*}{ Informação } & São dados dotados de relevância e propósito. & \multirow{6}{*}{$\begin{array}{l}\text { Relação de notas fiscais } \\
\text { canceladas em setembro de } \\
\text { 2003, agrupadas pelos } \\
\text { respectivos motivos. }\end{array}$} \\
\hline & Requer unidade de análise. & \\
\hline & Exige consenso sobre o significado. & \\
\hline & Exige necessariamente uma medição humana. & \\
\hline & Transferível com uma certa dose de esforço. & \\
\hline & $\begin{array}{l}\text { Exige uma camada de apresentação que a formate } \\
\text { em gráficos ou indicadores de desempenho. }\end{array}$ & \\
\hline \multirow{6}{*}{ Conhecimento } & É a informação valiosa na mente humana. & \multirow{6}{*}{$\begin{array}{l}\text { As causas mais expressivas de } \\
\text { atrasos nas entregas devem ser } \\
\text { evitadas, e a organização deve } \\
\text { aprender com tais erros, } \\
\text { trabalhando para evitar } \\
\text { cancelamentos e reclamações. }\end{array}$} \\
\hline & Inclui reflexão, síntese e contexto. & \\
\hline & De difícil estruturação. & \\
\hline & De difícil captura em máquina. & \\
\hline & De difícil transferência. & \\
\hline & De difícil apresentação e compartilhamento. & \\
\hline
\end{tabular}

Quadro 4 - Principais diferenças entre dados, informação e conhecimento.

Fonte: adaptada a partir de LEME FILHO (2004, pp. 11, 64). 
O Quadro 4 (acima) foi elaborado com o objetivo de resumir e, ao mesmo tempo, diferenciar didaticamente dados, informação e conhecimento, apresentando algumas características e exemplos de cada um destes conceitos.

\subsubsection{Conceito de sistemas e de ferramentas de apoio à decisão}

De acordo com Laudon e Laudon (2004), os SADs auxiliam os gerentes a tomar decisões não-usuais, ou como outros autores definem, decisões não estruturadas (BISPO, 1998). Os autores afirmam que os SADs embora utilizem informações internas provenientes dos SIGs, freqüentemente recorrem a informações de fontes externas, como por exemplo, cotação do dólar, índices de investimentos, preços de produtos de concorrentes, entre outras.

Ainda sobre os SADs, os autores complementam:

São projetados de modo que os usuários possam trabalhar com eles diretamente, incluem software de fácil interação com o usuário. Também são interativos: o usuário pode alterar as suposições, fazer novas perguntas e incluir novos dados. (LAUDON e LAUDON, 2004, p. 45).

Stair e Reynolds (2002) definem sistemas de apoio à decisão como um conjunto organizado de pessoas, procedimentos, softwares, banco de dados e dispositivos que são utilizados com a finalidade de dar suporte à tomada de decisão relacionada a problemas específicos.

Para Teixeira e Teixeira ${ }^{9}$ (2000 apud AQUARONI, 2001), os SADs são projetados para apoiar os gestores de negócio no processo de tomada de decisão, baseado em uma perspectiva de longo prazo, no fato real de uma informação.

Segundo Freire (2000), os SADs enfocam a decisão, com ênfase na flexibilidade, adaptabilidade e capacidade de fornecer respostas rápidas, voltado aos gerentes de alto nível e para os tomadores de decisão.

O principal objetivo desses sistemas, segundo Viotti e Braga (1998) é fornecer informações seguras e consistentes aos níveis tático e estratégico das empresas, a partir das quais as decisões poderão ser tomadas.

Já as ferramentas de apoio à decisão surgem como uma maneira computadorizada capaz de disponibilizar um conjunto de opções para a construção de

${ }^{9}$ TEIXEIRA, R. C. F.; TEIXEIRA, I. S. (2000). Abordagem sistêmica da gestão empresarial no processo competitivo. Disponível em http://upis.br/upis_web/revista_multipla/n_003/neto.htm. Acessado em 05/05/2004. 
um SAD de maneira rápida, fácil e com baixo custo. Essas ferramentas são implementadas ou colocadas em uso com finalidades e pré-requisitos definidos que atendam ao processo de tomada de decisão de determinado segmento de empresas ou processos de negócios genéricos. (VIOTTI e BRAGA, 1998).

Um exemplo da utilização das ferramentas de apoio à decisão, sobretudo as planilhas eletrônicas, pode ser obtido em O’Brien (2003):

\begin{abstract}
Os sistemas de apoio à decisão fornecem suporte computacional direto aos gerentes durante o processo de decisão. Os gerentes de propaganda podem utilizar um pacote de planilhas eletrônicas para realizar análise de simulação quando testam o impacto de orçamentos alternativos de propaganda sobre as vendas previstas para novos produtos. (O’BRIEN, 2003, p. 29).
\end{abstract}

\title{
2.4.3 Sistemas transacionais versus sistemas de apoio à decisão
}

Segundo Augusta (2001), os sistemas transacionais (SIGs) são sistemas que processam tarefas repetitivas e operacionais do negócio e os sistemas de apoio à decisão (SADs) são sistemas que fornecem informações úteis para a tomada de decisão, apresentando-se como sistemas diferentes para diferentes níveis na hierarquia.

Os sistemas transacionais dão suporte à operacionalização das transações do diaa-dia das empresas, porém, as informações que produzem não suprem as necessidades dos tomadores de decisão, que geralmente precisam de dados históricos decorrentes de períodos anteriores para realizarem consultas e simulações de acordo com o problema que precisam resolver.

\footnotetext{
Os sistemas transacionais são sistemas que envolvem um grande número de cálculos simples, mas altamente repetitivos, em geral não necessitam da intervenção humana enquanto os cálculos estão sendo realizados, pois são resultantes de tarefas muito estruturadas. (MEIRELLES, 1994, p. 40).
}

Viotti e Braga (1998), afirmam que apesar de haver diferenças entre os SIGs e os SADs, isso não significa que as características de um SAD não possam ser encontradas em um SIG, elas simplesmente não são comuns.

Segundo os autores, um SAD pode ser usado para a solução de problemas inesperados, ou ad hoc (destinados a determinadas finalidades), que exijam decisões realizadas geralmente apenas uma vez. Já a maioria dos SIGs suporta apenas decisões baseadas em informações estruturadas, pré-definidas e apresentadas através de relatórios e/ou consultas consolidadas. 
Um SAD pode oferecer uma representação válida para situações complexas do mundo real. Um SIG requer [...] técnicos especializados, e que muitas vezes perdem a validade com o tempo. Um SAD deve ser capaz de dar suporte imediato a decisões que envolvam situações novas ou inesperadas. Em um SIG, caso o modelo de dados disponível não atenda os requisitos do problema, será necessário um prazo bastante significativo para o desenvolvimento de novos programas e conseqüente obtenção de informações. (VIOTTI e BRAGA, 1998, p. 2).

Em termos de evolução, os SADs podem evoluir à medida que os tomadores de decisão aprendem mais sobre o problema do negócio. Isso ocorre, na maioria das vezes, porque os gerentes não conseguem especificar com antecedência o problema por razões de tempo e também em função da própria dinâmica do negócio, a qual traz novos cenários de decisão constantemente. Entretanto, em um SIG, todos os requisitos devem ser detalhados previamente para que seja formalizado o modelo de dados.

Outro ponto importante a destacar, conforme observa Viotti e Braga (1998), é que os SADs, de um modo geral, são utilizados ou desenvolvidos por profissionais ligados à área do problema a ser resolvido, e não à área técnica de informática. Isso é o oposto do que ocorre com os SIGs, que exigem alta capacitação técnica em informática de quem os implementa ou desenvolve.

Um modo interessante de analisar as diferenças básicas entre os SIGs e os SADs é relacioná-los com os níveis organizacionais aos quais atendem nas empresas. Teoricamente, um SIG atende de forma estruturada e pré-definida a todos os níveis. Ao passo que um SAD pode ser considerado como um sistema que utiliza os produtos de informação dos SIGs para atender aos dois níveis superiores (tático e estratégico), que lidam geralmente mais com decisões semi-estruturadas ou não-estruturadas (LAUDON e LAUDON, 2004; VIOTTI e BRAGA, 1998).

O Quadro 5, abaixo, resume as principais diferenças entre SIGs e SADs.

\begin{tabular}{|c|c|c|}
\hline Item & SIGs & SADs \\
\hline Tipo de usuário & Operacional & Analítico, decisório \\
\hline Função do usuário & Operar a empresa & Dirigir a empresa \\
\hline Ação dos sistemas & Processamento de dados & Síntese de informação \\
\hline Tempo de resposta & Segundos & Minutos \\
\hline Horizonte temporal & Meses & Anos \\
\hline Registros acessados & Alguns & Muitos \\
\hline Predominância de processamento & Atualização (inclusão/edição) & Por assunto \\
\hline Organização do banco de dados & Por aplicação & Exploratória, gerencial \\
\hline Tipo de utilização & Focada, repetitiva & Ad hoc (determinada finalidade) \\
\hline Tipo de consulta & Previsível, periódica & .
\end{tabular}

Quadro 5 - Principais diferenças entre sistemas transacionais (SIGs) e SADs.

Fonte: adaptada a partir de LEME FILHO (2004, p. 109). 


\subsubsection{Características, objetivos e benefícios dos sistemas de apoio à decisão}

De acordo com Sprague Júnior (1991), os sistemas de apoio à decisão possuem as seguintes características:

- Os SADs voltam-se para problemas menos estruturados e menos especificados com os quais os gerentes se deparam;

- Combinam o uso de modelos e técnicas analíticas a funções tradicionais de acesso e recuperação de informações;

- Concentram-se especificamente em recursos que facilitem seu uso para pessoal não especializado em computação; e

- Enfatizam a flexibilidade e a adaptabilidade de acomodar mudanças no ambiente e na abordagem ao processo decisório.

Segundo Viotti e Braga (1998), as características dos sistemas de apoio à decisão devem contemplar:

- Suporte aos vários níveis gerenciais existentes na empresa, abrangendo desde executivos de topo até os gerentes operacionais;

- $\quad$ Suporte tanto às decisões de um único indivíduo quanto às decisões que envolvam grupos de indivíduos;

- $\quad$ Suporte a todas as fases do processo decisório;

- $\quad$ Atendimento aos vários estilos e tipos de tomada de decisão;

- Interface gráfica sofisticada e amigável.

Greenfied (2004) destaca que os sistemas de apoio à decisão devem ter como objetivos:

- $\quad$ Fazer com que as "surpresas" do ambiente empresarial não sejam tão imprevisíveis;

- Dar confiança e sustentação às pessoas que utilizam suas informações;

- Simular cenários e projetar situações antes que elas ocorram;

- $\quad$ Proporcionar aos seus usuários uma maneira mais amigável de acessar as informações;

- Comparar informações sobre clientes, produtos, mercados consumidores e financeiros, ao longo do tempo em diferentes períodos (diário, semanal, mensal, trimestral, entre outros);

- Verificar a eficácia em alguns processos de negócio, medindo o que ocorreu de fato com os orçamentos, previsões, metas, ou outros tipos de objetivos; 
- $\quad$ Ajudar os gestores - usuários dessas ferramentas - a refinarem seus processos de tomada de decisão;

Coletar uma parte pequena das informações fora do grande volume encontrado nos sistemas transacionais;

- Confirmar e, às vezes descobrir, tendências e relacionamentos entre os dados do negócio, que muitas vezes passam despercebidos pelos tomadores de decisão;

- $\quad$ Apresentar objetivamente os fatos.

Para Turban (1995) os principais benefícios de um sistema de apoio à decisão são:

- $\quad$ Aumento de produtividade;

- Habilidade para suportar a solução de problemas complexos;

- $\quad$ Permite análise quantitativa em um tempo bastante curto;

- $\quad$ Percepção rápida de mudanças freqüentes em cenários complexos;

- $\quad$ Habilidade de simulação rápida e objetiva;

- $\quad$ Estabelecimento de critérios de análise;

- $\quad$ Gerentes inexperientes podem ser treinados com mais facilidade;

- $\quad$ Facilidade de comunicação;

- $\quad$ O processo de decisão dos gerentes tende a ter maior apoio das decisões organizacionais;

- Melhoria do controle e da performance do gerenciamento;

- $\quad$ Redução de tempo e esforço dos gerentes, que trabalham com maior qualidade e planejamento;

- $\quad$ Redução de custos eliminando ou reduzindo decisões erradas;

- $\quad$ Aumento de decisões mais objetivas e consistentes em detrimento as decisões intuitivas.

\subsubsection{Principais usos nas empresas dos sistemas de apoio à decisão}

As informações geradas e apresentadas por um sistema de apoio à decisão têm as mais diversas finalidades. Com o surgimento dos SADs e de toda a tecnologia envolvida nesses sistemas, os administradores passaram a contar com recursos e técnicas que exibem resultados dinâmicos e fantásticos (LEME FILHO, 2004). O autor ressalta que os dados que antes eram tratados de forma isolada, agora podem e devem ser integrados e contextualizados. 
Diante desse cenário, os diretores de grandes empresas e os tomadores de decisão/proprietários das pequenas e médias empresas, passam a dispor de recursos para acompanhar a velocidade e os rumos do mercado onde estão inseridos, utilizando os SADs para diversas finalidades.

A seguir, baseado nos estudos de Leme Filho (2004, p. 153), são descritos e exemplificados alguns dos principais usos dos SADs. É importante ressaltar que os exemplos de utilização que se seguem, independem de qual software será utilizado, sendo aplicáveis em grandes ou pequenas empresas.

A fim de facilitar a leitura e servir de apoio para a exploração do trabalho de campo, os exemplos de utilização dos SADs, a seguir, foram organizados de acordo com duas das principais áreas da administração de empresas, ou seja, marketing e finanças.

$\rightarrow$ Marketing

- Criação de novos produtos e serviços: pode ser realizado um estudo do volume de chamadas dos clientes à central de atendimento, agrupados pelos seus motivos. Por meio de um ranking, selecionam-se, por exemplo, as vinte principais razões, e os tomadores de decisão podem dar início a um trabalho de mapeamento daquilo que pode ser automatizado. Como conclusão do trabalho, uma lista de quatro ou cinco serviços novos (por exemplo, a consulta aos preços dos produtos) pode ser adicionada ao site da empresa na Internet, resultando, certamente, na queda do número de ligações, e conseqüentemente do custo.

Segmentação de mercado: uma empresa de benefícios, por exemplo, pode ter acesso privilegiado aos dados dos funcionários dos seus clientes, que não se restringem ao nome, mas se estendem ao salário e ao tempo de serviço. Com base nessas informações, é possível criar um novo segmento de atuação voltado para o empréstimo bancário à pessoa física.

- Retenção de clientes: em administradoras de cartão de crédito, por exemplo, pode se fazer um levantamento de uma boa amostra dos cartões de crédito, com as respectivas datas de criação, datas de ativação e de seus gastos. Com base nessa amostra, os peritos do negócio irão perceber que a partir de um determinado momento, não há muitas divergências nas compras. Este é o ponto que indica duas importantes variáveis: o prazo de maturidade dos clientes e valor médio gasto por eles. Diante 
dessas informações, pesquisa-se através do SAD quantos clientes ainda estão abaixo desse ponto. Os clientes apresentados nessa pesquisa ainda necessitam de investimento de marketing e propaganda. Dessa forma, a retenção fica mais eficaz, uma vez que pode haver clientes com valores abaixo da média que não tem tido mais propaganda, e exatamente o inverso, no caso de clientes com valores acima da média.

Análise de potencial: imaginando uma empresa cujo maior cliente seja um grande banco, os tomadores de decisão podem cruzar dados internos com dados de mercado, entre os quais a relação de todas as agências bancárias do país. Esse cruzamento de dados pode revelar que apesar desse grande banco ser o seu maior cliente, apenas um pequeno percentual de suas agências é atendido. Dessa maneira, chega-se à conclusão de que parte da sua força de vendas deve ser deslocada para angariar novas agências desse banco, uma vez que o custo para isso é bem menor do que conquistar novos clientes.

\section{$\rightarrow$ Finanças}

- Redução de despesas: considerando-se que as despesas podem ser tratadas como perdas financeiras evitáveis, o SAD torna-se um aliado dos cortadores de custos, que podem partir de assuntos de dados característicos para tal função, tais como centrais de atendimento, distribuição, produção, estocagem, distribuição, atividades legais que implicam em multas, entre outros.

- Rentabilidade de clientes: em uma indústria ou comércio, onde seus sistemas são integrados, todo o ciclo de vida de um cliente pode ser analisado a partir de uma visão unificada. Por exemplo, examinar o comportamento do cliente desde o momento do pedido até a entrega do mesmo, passando pela manufatura, compra de matéria-prima, contas a pagar, faturamento, contas a receber, entre outros. Essa análise deve ter como foco a detecção daqueles clientes que representam prejuízos para a empresa, para que os tomadores de decisão possam decidir sobre revisões de descontos, taxas, cláusulas de contrato, entre outras atitudes.

- Simulações e análise de tendências: são aquelas análises do tipo "seentão", que permitem aos usuários de SADs variarem certos valores para testar resultados, bem como para prever com mais exatidão as conseqüências caso realmente ocorram mudanças desses valores. 


\subsection{FERRAMENTAS DE APOIO À DECISÃO}

Para Manzini ${ }^{10}$ (2001 apud CAZARINI, 2002), as ferramentas de apoio à decisão não podem ser muito complexas, pois não serão os profissionais da área técnica que as utilizará, e sim os tomadores de decisão, os profissionais da área de negócios. Entretanto, complementa o autor, essas ferramentas precisam ser robustas e flexíveis o bastante para dar agilidade no acesso e manipulação das informações de apoio à decisão.

Esta seção visa apresentar algumas das principais ferramentas disponíveis de apoio à decisão para as empresas, sobretudo, para as de pequeno porte.

Para isso, realizou-se um levantamento bibliográfico através do trabalho realizado por três pesquisadores da linha de apoio à decisão e geração do conhecimento (CAZARINI, 2002; COLMANETTI, 2003; OSTANEL, 2005).

De acordo com Cazarini (2002), existem várias maneiras de se acessar e manipular informações de um sistema de apoio à decisão. Segundo a autora e de acordo com conhecimento próprio, as formas mais comuns existentes no mercado são os geradores de consultas, geradores de relatórios, softwares que utilizam características OLAP e as planilhas eletrônicas.

Para Colmanetti (2003), uma das ferramentas que podem apoiar a decisão e a geração de conhecimento nas empresas, é o correio eletrônico. A autora em sua obra propõe o que considera ser as boas práticas de utilização do correio eletrônico, sobretudo na pequena empresa.

Complementando, Ostanel (2005) propõe a utilização da Internet como ferramenta de suporte informacional à gestão da pequena empresa. Para isso, o autor destaca a Internet como fonte atualizada de informação, a qual vem ao encontro da "necessidade informacional do gestor de pequena empresa e das limitações que o mesmo sofre em seu cotidiano, principalmente de tempo, para se atualizar e poder decidir de forma mais precisa" (OSTANEL, 2005, p. 81).

Deste modo, baseado no levantamento bibliográfico realizado nas obras anteriormente citadas e de acordo com o conhecimento do próprio pesquisador, são apresentadas nas próximas subseções as principais características destas ferramentas, a saber:

\footnotetext{
10 MANZINI, B. R. (2001). Ainda há tempo para acertar? Disponível em http://www.crm.inf.br. Acessado em 25/04/2001.
} 
- $\quad$ Geradores de consultas;

- $\quad$ Geradores de relatórios;

- $\quad$ Softwares que utilizam características OLAP;

- Planilhas eletrônicas;

- Internet;

- $\quad$ Correio eletrônico;

- Groupware.

Essas ferramentas e suas principais características servirão de base para a exploração do ambiente de apoio à decisão na pequena empresa, a fim de levantar de que forma possíveis ferramentas computacionais podem auxiliar o tomador de decisão destas empresas.

\subsubsection{Geradores de consultas}

Também conhecidos como gerenciadores de consultas ou queries, são ferramentas que possuem ambiente interativo e, na maioria das vezes, amigável, cujo principal objetivo é realizar consultas.

Essas ferramentas permitem armazenar as consultas geradas para posteriores acessos, além de possibilitar que os dados gerados possam ser resumidos e apresentados em formato apropriado ao usuário.

\subsubsection{Geradores de relatórios}

São semelhantes às ferramentas do item anterior, porém são voltadas para a geração de relatórios mais complexos, contento, por exemplo, relatórios sintéticos e analíticos em conjunto, além de gráficos e outros tipos de visualização de dados.

\subsubsection{Softwares que utilizam características OLAP}

As ferramentas que utilizam das características OLAP (on line analytical processing), podem ser consideradas como pertencentes à nova geração de sistemas de apoio à decisão.

Estas ferramentas são constituídas por um conjunto de tecnologias especialmente projetadas para dar suporte ao processo decisório através de consultas, análise e cálculos mais sofisticados dos dados corporativos. 
As ferramentas OLAP podem ser implementas para ambientes multiusuários, arquitetura cliente-servidor, e oferece respostas rápidas e consistentes às consultas interativas executadas pelos analistas e tomadores de decisão. Os resultados dessas consultas podem ser analisados de várias maneiras, ou seja, resumidos, detalhados, por partes da informação, filtrados, ordenados, entre outras formas. Além disso, esses resultados podem ser apresentados de forma gráfica ou em formato de planilhas.

As características da tecnologia OLAP estão presentes em diversos sistemas de apoio à decisão. Na Figura 5, abaixo, tem-se um exemplo da presença da tecnologia OLAP nas planilhas eletrônicas, um dos aplicativos mais difundidos entre as empresas, principalmente as de pequeno porte.

Em função de sua forte presença nas pequenas empresas, as planilhas eletrônicas serão tratadas separadamente, na próxima subseção.

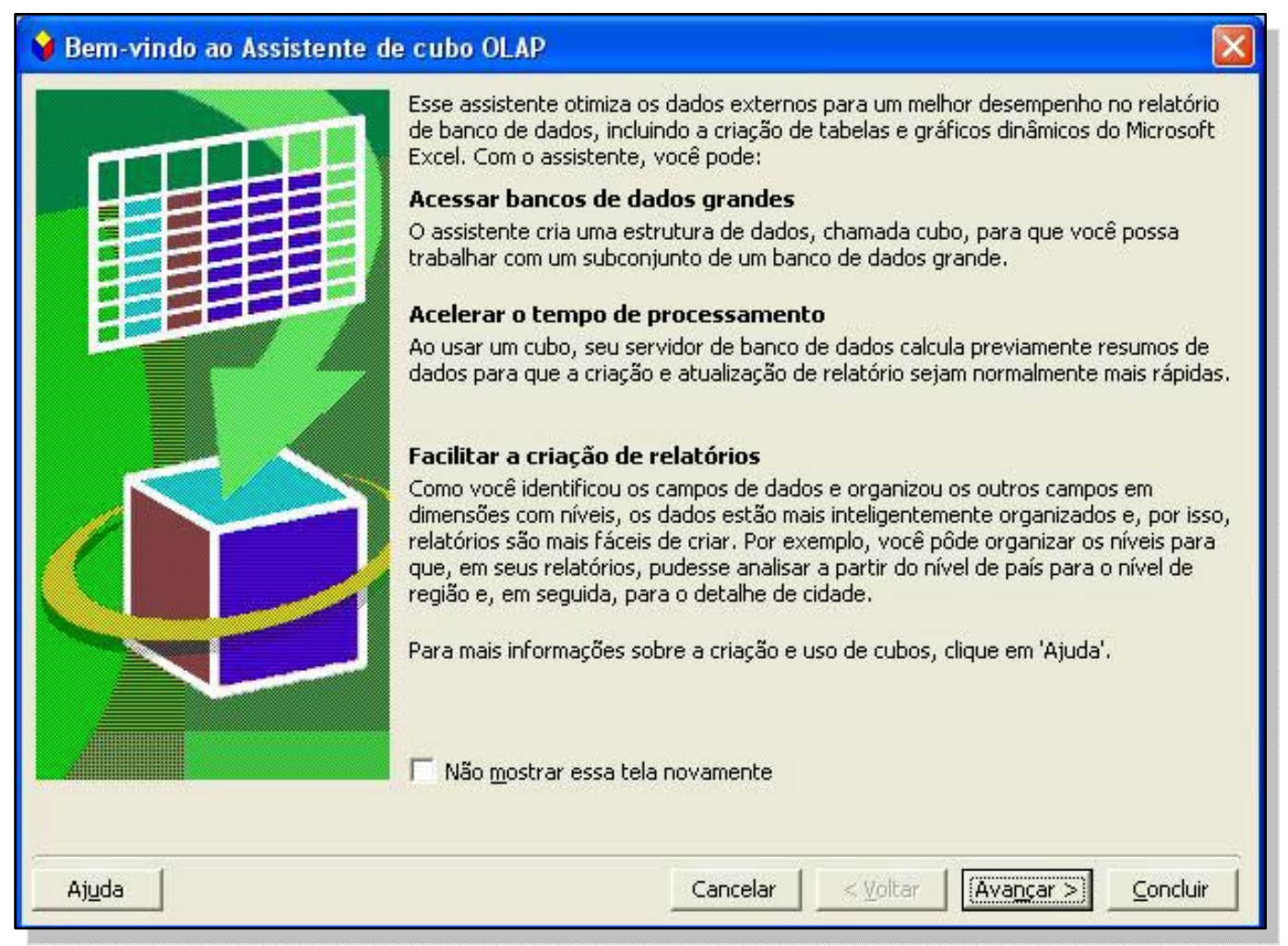

Figura 5 - Características OLAP presentes nas planilhas eletrônicas.

Fonte: MS-Excel.

\subsubsection{Planilhas eletrônicas}

Várias são as atividades em uma empresa que exigem a preparação de uma planilha onde são tabulados valores para a realização dos mais diversos cálculos e análises. As planilhas eletrônicas têm com um de seus maiores objetivos a apresentação 
de valores que representam o resumo de uma situação passada na empresa ou uma previsão de atividades futuras (LEME FILHO, 2004).

Observa-se, portanto, que as planilhas eletrônicas podem ser utilizadas tanto para controlar atividades já realizadas pela empresa, como para atividades que serão realizadas no futuro. Além disso, podem ser utilizadas tanto para controle como para planejamento, seja no nível operacional, tático ou estratégico.

Sprague Júnior e Watson (1991) em sua obra sobre sistemas de apoio à decisão, lançaram o que consideravam na época como o futuro sobre esse tema. Entre algumas das prováveis tendências, os autores afirmaram que:

DSS (decision support systems) baseados em computadores pessoais continuarão a se desenvolver. As planilhas eletrônicas terão cada vez mais funções, acabando por assumir algumas das funções anteriormente exercidas pelos geradores de DSS. (SPRAGUE JÚNIOR e WATSON, 1991, p. 3).

Outros autores também confirmavam há mais de dez anos atrás, através de seus estudos sobre a utilização das planilhas eletrônicas, a difusão dessas ferramentas nas empresas no tocante ao suporte à decisão. Cragg e $\operatorname{King}^{11}$ (1992a, 1992b apud HOLSAPPLE e WHISTON, 1996, p. 186) afirmam em pesquisas da época que "as planilhas eletrônicas voltadas para o suporte à decisão estão com seu uso difundido atualmente".

Confirmando essas tendências, autores contemporâneos destacam as planilhas eletrônicas como integrantes da classe dos sistemas de apoio à decisão (LAUDON e LAUDON, 2004; O'BRIEN, 2003). Esses autores ressaltam ainda que as planilhas eletrônicas são freqüentemente utilizadas para responder às perguntas do tipo "seentão", bastando para isso que o tomador de decisões simplesmente altere o valor de determinada fórmula e analise o seu resultado.

Desse modo, as planilhas eletrônicas constituem-se como ferramentas de suporte à decisão, as quais, segundo Coles e Rowley (1996), beneficiam o contato de gerentes com o uso efetivo da tecnologia da informação e o desenvolvimento de modelos que auxiliam na tarefa de decidir. As autoras mencionam também que as planilhas eletrônicas têm recursos suficientes para integrar o ambiente de sistemas de apoio à decisão e serem amplamente utilizadas como tal.

11 CRAGG, P. B.; KING, M. (1992a). A review and research agenda for spreadsheet based DSS. International Society for Decision Support Systems Conference, Ulm, Germany. (1992b). Spreadsheet modeling practice. Loughborough University Management Research Series, Loughborough University Business School, Leicestershire, UK. 
De modo especial, nas pequenas empresas as planilhas eletrônicas constituem-se como alternativas de ferramentas de apoio à decisão acessíveis e adaptáveis à realidade dessas empresas, pois conforme afirmam Pemberton e Robson (2000), o relativo baixocusto e a flexibilidade presente nas planilhas configuram-se como fatores importantes para a sua utilização.

De olho neste grande mercado, e conhecedor das potencialidades das planilhas eletrônicas, um de seus maiores fabricantes, a Microsoft, prepara para breve o lançamento de uma nova versão do pacote Office, cujo codinome é Office 12 (MICROSOFT, 2005).

De acordo com a Microsoft (2005), os aplicativos da família Office, sobretudo as planilhas eletrônicas do Excel, serão incorporadas com funcionalidades e recursos extras de business intelligence, visando apoiar mais os tomadores de decisão.

\title{
2.5.4.1 Conceito e evolução das planilhas eletrônicas
}

Segundo O’Brien (2003), a planilha eletrônica é:

\begin{abstract}
Um modelo de linhas e colunas que podem ser armazenadas em seu PC ou em um servidor de rede, ou convertidas em formato HTML e armazenadas como uma página de rede ou [...] na Internet. O desenvolvimento de uma planilha envolve o desenho de seu formato e o desenvolvimento das relações (fórmulas) que serão utilizadas no modelo. (O'BRIEN, 2003, p. 83).
\end{abstract}

Holsaplle e Whinston (1996) em sua obra sobre sistemas de apoio à decisão, definem planilhas eletrônicas como folhas de trabalho eletrônicas, representadas por grades de células, onde cada célula pode ter uma definição e um valor. Segundo os autores, uma definição de célula é uma expressão que especifica o que será calculado quando aquela célula foi acionada. Às vezes todas as expressões das células para uma determinada planilha são chamadas, constituindo assim um modelo de planilha eletrônica.

Corroborando com outros autores, Holsaplle e Whinston (1996) afirmam que análises do tipo "se-então" podem ser realizadas com facilidade nas planilhas eletrônicas, uma vez que alterando o conteúdo de determinadas células, os resultados são prontamente exibidos na tela, constituindo-se assim como valiosas ferramentas de apoio à tomada de decisão. Além disso, os autores destacam que os usuários de planilhas eletrônicas têm muito mais poder para controlar as informações e o 
conhecimento existente nessas ferramentas, pois além de criar, podem visualizar e modificar as informações contidas nesse tipo de SAD.

No que diz respeito à evolução das planilhas eletrônicas, elas datam desde a época onde eram usadas na forma de papel quadriculado por contadores para organizar em linhas e colunas os dados sobre transações de uma empresa (PEMBERTON e ROBSON, 2000; POWER, 2003). Dados sobre custos, renda, impostos, e outros, eram relacionados em uma única folha de papel para um gerente examinar e tomar decisões.

Com o avanço da computação, as planilhas tornaram-se eletrônicas, sendo a VisiCalc a primeira a ser comercializada. Após alguns anos, surgiu a planilha Lotus 1-23, com recursos mais avançados e finalmente entre 1984 e 1985, a Microsoft lança a planilha Excel, que se consolida até hoje como a mais utilizada pelo mercado por possuir sofisticados recursos, ser amigável e altamente integrada aos demais aplicativos existentes.

\subsubsection{As planilhas eletrônicas como ferramentas de apoio à decisão}

Em sua obra sobre business intelligence no MS-Excel, Leme Filho (2004) considera que um dos fatores críticos de sucesso para o desenvolvimento de um ambiente de suporte à decisão é a forma de visualização das informações. $O$ autor aponta para o grande número de aplicativos existentes no mercado destinados para essa finalidade, e justifica a escolha das planilhas eletrônicas como a mais adequada para suprir essa necessidade devido ao poder da ferramenta, à sua adaptabilidade e ao seu custo. $\mathrm{O}$ autor argumenta ainda:

- $\quad$ Poder da ferramenta: as planilhas eletrônicas tornaram-se cada vez mais robustas, e passaram a ter um papel muito maior do que a realização de simples cálculos, como por exemplo, a formação de bancos de dados para que seus usuários trabalhassem os dados conforme desejarem. Percebe-se nos últimos anos que a interface das planilhas eletrônicas não mudou muito, sugerindo uma fase de maturidade, a qual favorece a sua utilização por parte de diferentes pessoas de várias áreas, com baixo custo de treinamento.

Adaptabilidade: as planilhas eletrônicas, juntamente com os editores de texto, são partes integrantes de qualquer família de software que as empresas adquirem para seus computadores, atendendo desde grandes empresas até empresas de pequeno porte. 
- Custo: ao se analisar qualquer ferramenta de apoio à decisão existente no mercado, os valores envolvidos podem atingir centenas de milhares de dólares. Dessa maneira, as planilhas eletrônicas apresentam-se como uma alternativa para melhorar a relação custo/benefício, pois uma grande maioria de empresas já possui esse software, tendo pagado as taxas de aquisição e licenças aos fabricantes.

As planilhas eletrônicas são compostas por diversos recursos de análise de dados, cálculos e fórmulas estatísticas, os quais são capazes de gerar e difundir informações aos usuários tomadores de decisão. Entretanto, seu potencial é pouco explorado pelos profissionais.

Nas próximas subseções são descritas algumas das principais funcionalidades para apoio à decisão presentes nas planilhas eletrônicas, ilustradas com algumas imagens da nova versão desses aplicativos.

Contudo, é importante destacar que o objetivo destas subseções não é abordar aspectos de ordem técnica, como passos de instalação, acesso detalhado a menus e outras considerações básicas. Mas sim, expor as principais funções de apoio à decisão para que possam ser confrontadas com a real utilização destas ferramentas pelas pequenas empresas exploradas no estudo de caso.

$\mathrm{O}$ confronto entre essas funcionalidades e o seu uso real pelas pequenas empresas, proporcionará informações necessárias para se atingir o objetivo desta pesquisa, o qual é explorar de que forma as ferramentas computacionais podem auxiliar o tomador de decisão nas empresas de pequeno porte.

\section{$\rightarrow$ Gráficos}

Os gráficos são utilizados para representar um conjunto de dados contidos em uma planilha. É possível gerar diferentes tipos de gráficos, em diferentes formatos. Os gráficos são vinculados ao conteúdo da planilha, ou seja, qualquer alteração no conjunto de dados que originou o gráfico provocará sua respectiva alteração.

A vantagem da utilização de gráficos está na visualização dos dados dispostos de maneira visual, possibilitando uma melhor compreensão da sua representatividade e da sua evolução, o que pode auxiliar o tomador de decisão, influenciando diretamente na escolha de uma ou outra opção. 
Por exemplo, a análise da variação entre a demanda e a oferta de produtos em uma pequena empresa comercial pode ser representada em um gráfico, apoiando assim, diversas análises sobre vendas e fornecimentos de materiais ao longo de um ano.

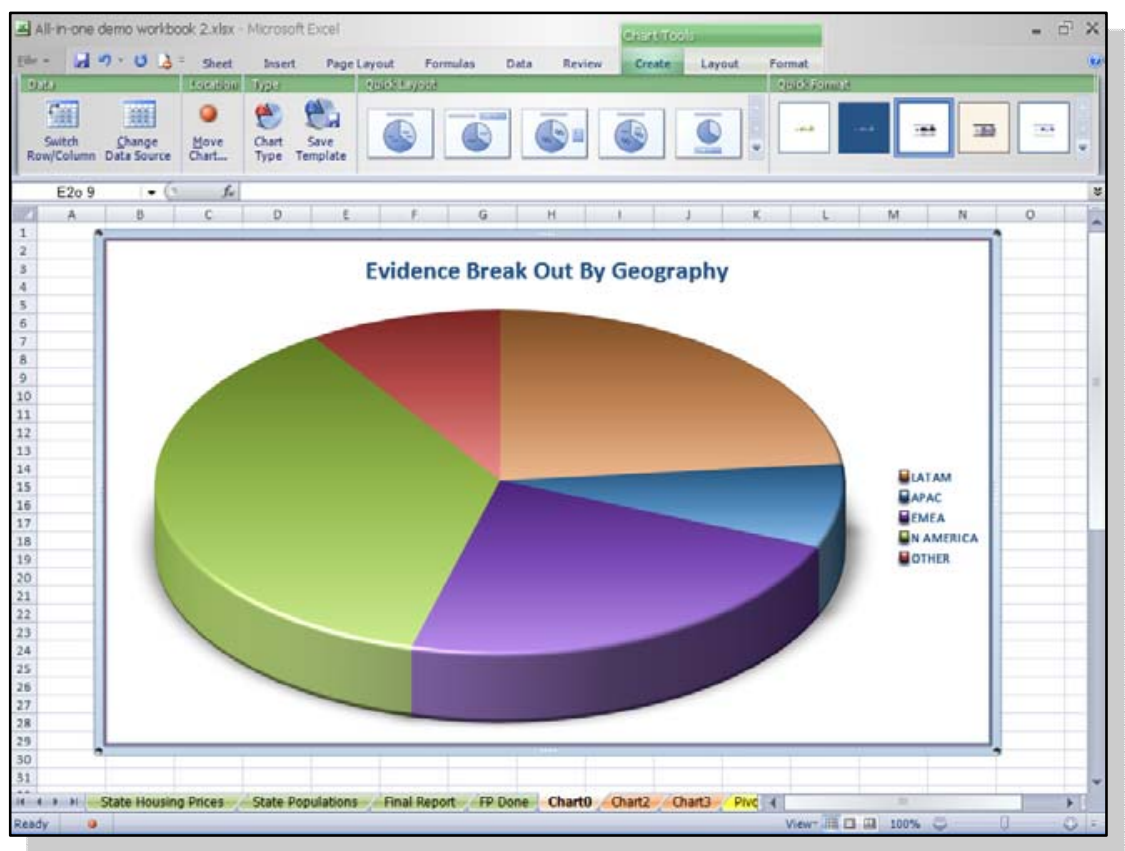

Figura 6 - Funcionalidades para apoio à decisão - gráficos.

Fonte - MICROSOFT (2005).

\title{
$\rightarrow$ Tabelas dinâmicas
}

Para Leme Filho (2004), as tabelas dinâmicas ou pivot tables (Figura 7), representam uma ótima modalidade de visualizar e explorar o potencial dos dados de uma planilha. De acordo com o autor, a partir de uma lista ou de um banco de dados, é possível o cruzamento das informações, variando linhas e colunas relacionadas.

Leme Filho (2004) afirma:

\begin{abstract}
A formatação da planilha não é um fator importante nesse caso, pois esta será base para a construção da tabela dinâmica e não será visualizada. Contudo, a construção deve ter a aparência de um banco de dados ou de uma lista, com um rótulo de dados na primeira linha e, muitas vezes, repetindo valores nas demais linhas. (LEME FILHO, 2004, p. 293).
\end{abstract}

Os recursos oferecidos pelas tabelas dinâmicas permitem aos usuários/tomadores de decisão de uma pequena empresa, terem contato com uma outra tecnologia existente na classe dos SADs, conhecida como OLAP, possibilitando que os dados organizados nas tabelas resultantes sejam visualizados segundo as necessidades do analista, que pode agrupar, contar ou sumarizar as informações, além de poder relacioná-las entre si. 


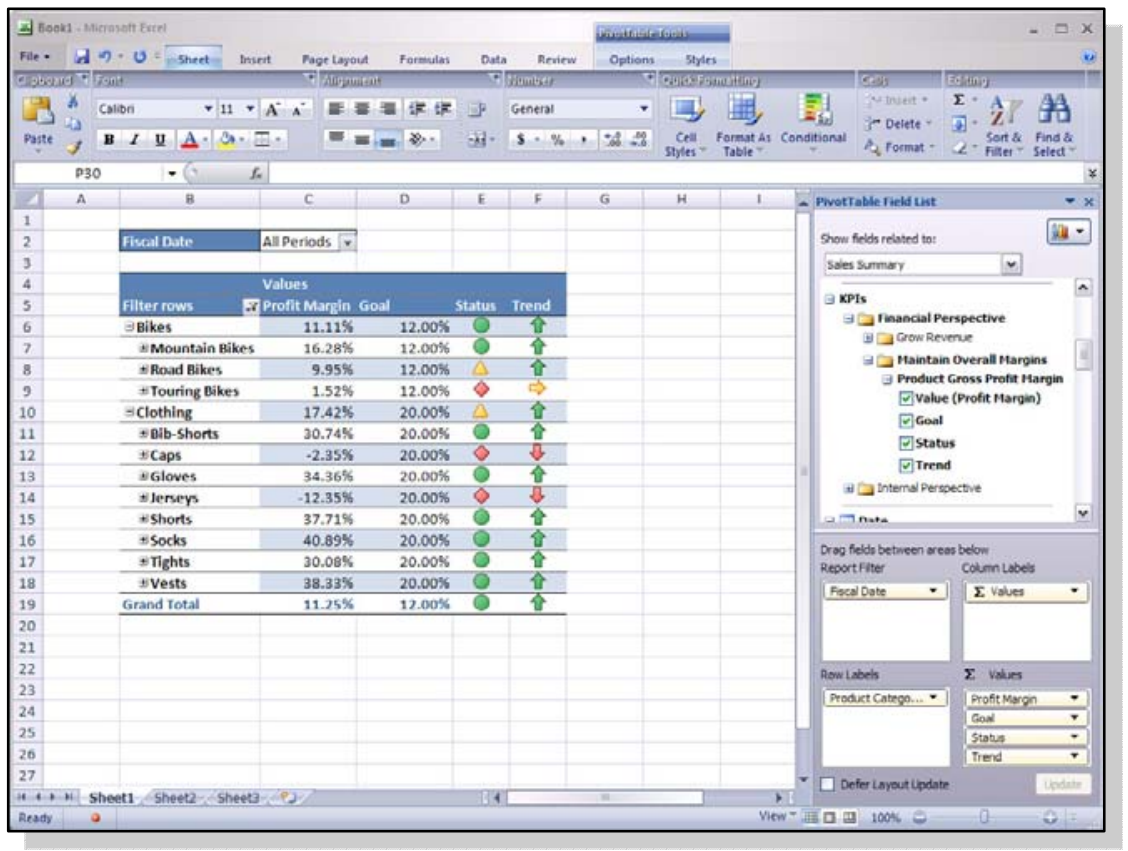

Figura 7 - Funcionalidades para apoio à decisão - tabelas dinâmicas.

Fonte-MICROSOFT (2005).

\section{$\rightarrow$ Atingir meta}

O recurso atingir meta é uma das ferramentas de análise mais simples encontradas nas planilhas, uma vez que trabalha utilizando apenas uma única variável. É útil quando se deseja que uma fórmula se iguale a um valor em particular, especificando uma célula onde a fórmula seja dependente.

O procedimento deste recurso consiste em alterar o valor da célula de entrada da fórmula até que o resultado esperado seja atingido. Sua maior utilidade ocorre então quando é necessário resolver uma fórmula onde se tem o conhecimento do resultado final e esse resultado depende de uma única variável, porém não se sabe qual o valor de entrada para que o resultado seja atingido.

Por exemplo, suponha que se deseja saber qual é a taxa de juros simples, para que um capital de R $\$ 1000,00$ aplicados por dez meses possa resultar em um montante de $\mathrm{R} \$ 1.500,00$. Este problema pode ser resolvido utilizando o recurso atingir meta.

$\mathrm{O}$ atingir meta utiliza um método iterativo para achar o valor que atenda a situação proposta. Uma das limitações desse recurso é que ele somente pode ser utilizado para problemas de uma única variável. Por exemplo, não se pode utilizar o comando atingir metas para determinar a taxa de juros e o prazo, para um determinado 
empréstimo, que produzam um valor específico para a prestação. Para estes casos, existe um outro recurso chamado solver, descrito mais adiante.

\section{$\rightarrow$ Cenários}

Um cenário é um conjunto de valores armazenados e que podem substituir automaticamente os valores atuais da planilha, facilitando a simulação de diferentes situações para diferentes valores.

Cada combinação ou série de valores é um cenário. É possível criar quantos cenários forem necessários para a planilha.

Para cada cenário pode ser atribuído um nome, o que facilita a organização e reconhecimento das diferentes séries de valores que cada cenário armazena. Após a construção dos cenários é possível imprimir um relatório que compara os cenários diferentes.

\section{$\rightarrow$ Solver}

Leme Filho (2004) define o solver como um recurso poderoso para se resolver problemas que podem ter diversas variáveis, permitindo também que sobre estas variáveis sejam especificadas restrições, além de possibilitar a criação de relatórios sobre o problema tratado.

O solver é uma ferramenta de software que ajuda os usuários a encontrar a melhor maneira de alocar recursos. Os recursos podem ser materiais crus, tempo de máquina ou tempo das pessoas, dinheiro, ou qualquer outra coisa em quantidade limitada.

O solver está baseado no princípio de encontrar a solução ótima para um problema.

\section{$\rightarrow$ Outros recursos de apoio à decisão}

Além dos recursos apresentados anteriormente, as planilhas eletrônicas são compostas de outras funcionalidades de apoio à decisão, como os filtros e, na futura versão das planilhas Excel da Microsoft, o portal corporativo (vide Figura 8, abaixo). 


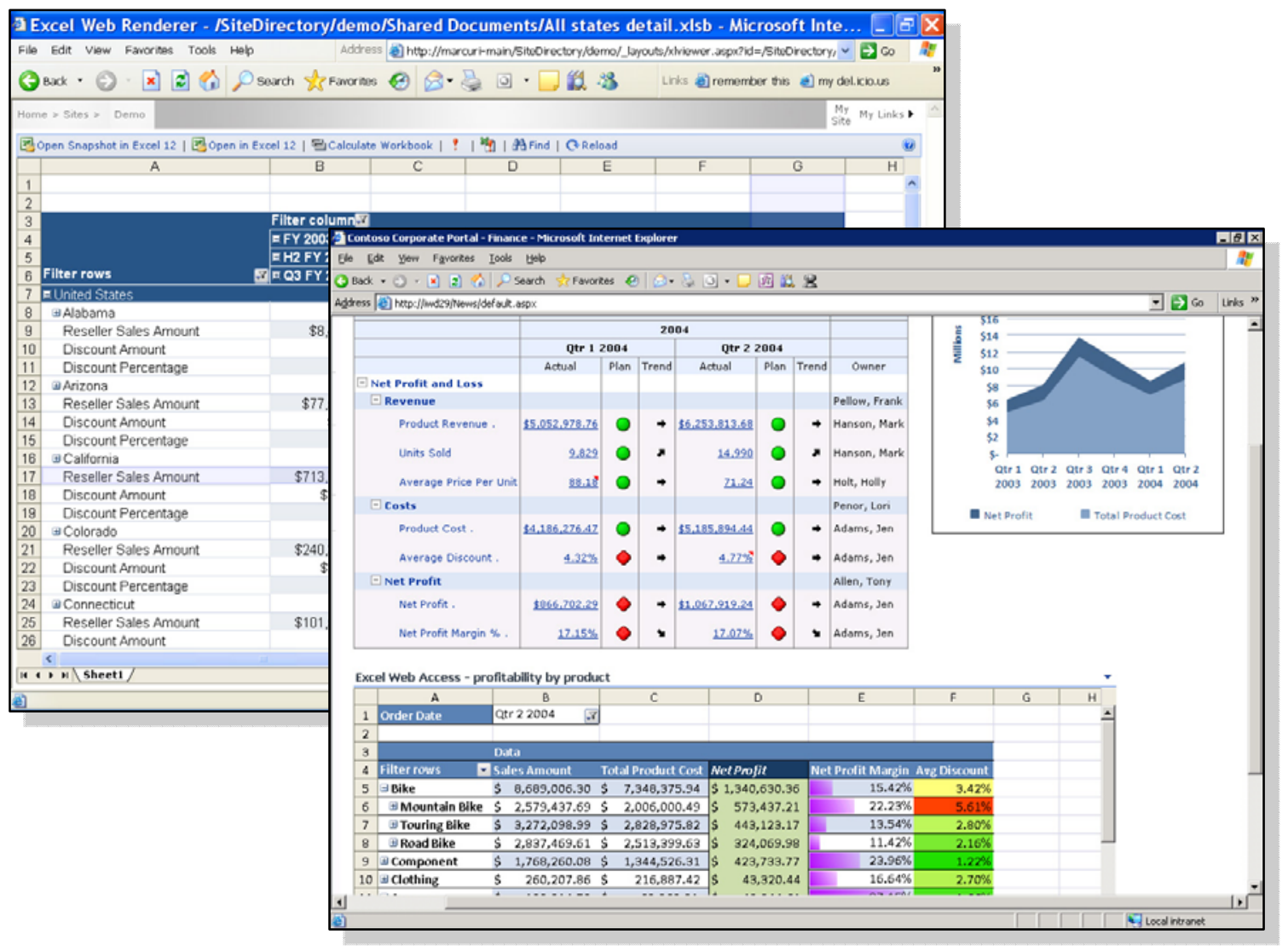

Figura 8 - Funcionalidades para apoio à decisão - filtros e portal corporativo. Fonte-MICROSOFT (2005).

\subsubsection{Internet}

Segundo Ostanel (2005), a Internet pode ser considerada como o conjunto de diversas redes de computadores que se comunicam através de protocolos TCP/IP.

Para Fiates (2001), o surgimento da Internet representou um grande marco na história da tecnologia, pois proporcionou condições para o fluxo irrestrito de idéias e também de conhecimento. Desta forma, mais do que ser apenas um elemento da tecnologia da informação, a Internet pode ser considerada como impulsionadora e símbolo da globalização e da dinâmica do mundo moderno.

De acordo com O’Brien (2003), as mais conhecidas aplicações da Internet são:

- $\quad$ E-mail;

- $\quad$ Navegação em sites;

- $\quad$ Participação em grupos de notícias.

No entanto, no ambiente empresarial, um dos maiores benefícios que a Internet proporciona às empresas, independente do seu porte, diz respeito à facilidade e 
agilidade na comunicação e na troca de informações entre os diversos elos da cadeia de suprimentos.

Corroborando com O'Brien (2003), acredita-se que o uso comercial da Internet está se desenvolvendo da troca de informações eletrônicas para uma plataforma ampla para as aplicações empresariais estratégicas. Para o autor, a Internet pode ser considerada como de uso comercial a partir do momento em que proporciona as condições para:

- $\quad$ A colaboração entre os diversos parceiros empresariais;

- $\quad$ O fornecimento de suporte aos clientes e à força de vendas;

- A compra e a venda de produtos e serviços

Além disso, a Internet permite aos tomadores de decisão das empresas acessarem informações relevantes, principalmente aquelas relacionadas ao seu ambiente externo (governo, concorrência, etc.).

Segundo Ostanel (2005), isto é possível, pois o acesso aos sites interativos, o uso do e-mail, dos grupos de discussão, das conversas on-line e das videoconferências, permitem às empresas realizar pesquisas, solicitar, disseminar e compartilhar informações comerciais internas e externas.

\subsubsection{Correio eletrônico}

De acordo com Colmanetti (2003), o correio eletrônico pode ser considerado como uma aplicação da Internet para comunicação entre usuários através de mensagens de correio. Pode ser considerada ainda, como uma ferramenta assíncrona (não on-line) de comunicação, a qual se constitui na principal aplicação da Internet até o momento (FIATES, 2001).

As mensagens de e-mail, muitas vezes, incorporam e carregam consigo preciosas informações sobre clientes, fornecedores, concorrentes, o mercado em geral, resultado de pesquisas e sobre o trabalho dos funcionários (FIGUEIREDO ${ }^{12}, 2002$, apud COLMANETTI, 2003). Entretanto, nem sempre o correio eletrônico é reconhecido pelas empresas como uma ferramenta de apoio à decisão e geração de conhecimento.

Para Colmanetti (2003), as principais vantagens do correio eletrônico são:

- Melhoria na produtividade dos funcionários;

\footnotetext{
${ }^{12}$ FIGUEIREDO, S. P. (2002). Gestão do conhecimento a partir do e-mail. Informal. Disponível em http://www.informal.com.br/artigos. Acessado em 10/07/2002.
} 
- $\quad$ Diminuição do fluxo de papéis;

- $\quad$ Agilização das tarefas operacionais;

- $\quad$ Redução dos níveis hierárquicos;

- $\quad$ Aumento do grau de participação nos processos de trabalho;

- $\quad$ Formalização da informação transmitida;

- Utilização de outros recursos que apóiam o trabalho dos funcionários, como calendários, agendas, catálogos de endereços, entre outros;

- $\quad$ Facilidade de uso;

- $\quad$ Baixo custo;

- $\quad$ Otimização do tempo.

Além destas vantagens, a utilização do correio eletrônico pelas empresas permite a discussão e análise das alternativas antes de se tomar uma decisão, bem como aumenta o grau de participação das pessoas nos processos decisórios. Cavalcanti, Gomes e Pereira (2001, p. 133) ilustram isso ao destacar a presença do correio eletrônico em uma determinada empresa, onde "o correio eletrônico é uma das ferramentas de interação [...] tanto interna quanto externamente. [...] Esta ferramenta é utilizada para discutir as ações, para construir o consenso e para tomar decisões.”.

\subsubsection{Groupware}

Segundo Colmanetti (2003), o groupware pode ser definido como sendo aplicações que, além das redes locais e das infra-estruturas de telecomunicações das empresas, permitem o trabalho em equipe sobre projetos comuns em um ambiente compartilhado.

Para o CRIE (Centro de Referência em Inteligência Empresarial), o groupware representa uma família de aplicações, baseadas em computador, que dão suporte a grupos de pessoas (trabalho colaborativo) engajadas em uma tarefa comum, provendo uma interface amigável em um ambiente compartilhado (CRIE, 2004). Estas ferramentas provêem as condições necessárias para:

- Centralizar, uniformizar e padronizar a comunicação entre um grupo de trabalho;

Trocar informações e conhecimento, colaborando e dinamizando as atividades de um grupo de trabalho; 
- Tomar decisões rápidas, pautadas em informações confiáveis sobre o grupo e suas atividades.

De acordo com Colmanetti (2003) e baseado em conhecimento próprio, as ferramentas de groupware apóiam a colaboração entre as pessoas através de:

- $\quad$ Gerenciamento de e-mail;

- $\quad$ Correio de voz;

- $\quad$ Fórum de discussão;

- Vídeo conferência;

- $\quad$ Agendas e calendários compartilhados.

De uma forma geral, pode-se considerar que as ferramentas de groupware são aquelas que têm as condições necessárias para dar assistência aos grupos de trabalho no tocante à comunicação, colaboração e coordenação de suas atividades. Elas devem permitir que duas ou mais pessoas trabalhem juntas compartilhando seus conhecimentos e especialidades, bem como, automatizando algumas de suas atividades (COLMANETTI, 2003). 


\section{CAPÍTULO 3 - METODOLOGIA DA PESQUISA}

\subsection{CONSIDERAÇÕES INICIAIS}

Segundo Come (2001), a pesquisa é o procedimento racional e sistemático que visa proporcionar respostas aos problemas que são propostos e assim contribuir com o conhecimento científico. De acordo com Gil (2002), a pesquisa é requerida quando não se dispõe de informação suficiente para responder ao problema, ou então quando a informação disponível se encontra em tal estado de desordem, impossibilitando a sua adequada relação com o problema.

A metodologia adotada demonstra como a pesquisa será implementada, qual a forma de abordagem, os métodos e as técnicas que melhor se enquadram na problemática do trabalho científico, tendo em vista a obtenção dos seus resultados (CERVO e BERVIAN, 2002). Gil (2002) salienta a utilização cuidadosa dos métodos, técnicas e outros procedimentos científicos e destaca a importância do planejamento efetivo das ações desenvolvidas ao longo do processo de pesquisa.

Silva (2002), em sua análise sobre a vasta utilização do estudo de caso na produção discente de pós-graduação em administração, destaca a importância do conhecimento e da escolha metodológica para o resultado eficiente do trabalho científico.

[..] se a escolha metodológica não é fundamentada em um processo de análise de sua abrangência e na dimensão da pesquisa a ser realizada, pode-se optar por uma estratégia de pesquisa sem que se tenha um conhecimento aprofundado de suas potencialidades e limitações, o que pode resultar em um trabalho deficiente. (SILVA, 2002, p. 84).

Portanto, este capítulo tem como objetivo discutir e apontar os aspectos metodológicos estudados para o desenvolvimento desta pesquisa, destacando os métodos e as etapas de investigação adotadas. 


\subsection{FORMA DE ABORDAGEM DA PESQUISA}

Godoy (1995) estabelece a diferença entre um estudo com abordagem quantitativa e qualitativa, ao referir-se à condução do trabalho do pesquisador na abordagem quantitativa. Para a autora, esta abordagem se preocupa com a medição objetiva e a quantificação dos resultados, buscando a precisão, evitando distorções na etapa de análise e interpretação dos dados, para garantir assim, uma margem de segurança em relação às inferências obtidas.

No entanto, a pesquisa qualitativa, de acordo com a autora, ao contrário da quantitativa, não procura enumerar e/ou medir os eventos estudados, nem emprega instrumental estatístico na análise dos dados. Para a autora a pesquisa qualitativa:

parte de questões ou focos de interesses amplos, que vão se definindo à medida que o estudo se desenvolve. Envolve a obtenção de dados descritivos sobre pessoas, lugares e processos interativos pelo contato direto do pesquisador com a situação estudada, procurando compreender os fenômenos segundo a perspectiva dos sujeitos, ou seja, dos participantes da situação em estudo. (GODOY, 1995, p. 58).

Cabe definir ainda, segundo Godoy (1995), a expressão ciências sociais como sendo aquelas que se preocupam com os fenômenos sociais, econômicos, políticos, culturais, educacionais, enfim, fenômenos que englobam relações de caráter humano e social.

\subsection{TIPO DE INVESTIGAÇÃO DA PESQUISA}

Os critérios para a classificação dos tipos de pesquisa variam de acordo com o enfoque dado pelos autores. A divisão obedece a abordagens, interesses, condições, campos, metodologia, situações, objetivos, objetos de estudo, entre outros (MARCONI e LAKATOS, 2002). Na obra de Marconi e Lakatos (2002), são apresentados nada menos que oito tipos de pesquisa, cada qual baseada em determinados critérios.

Gil (2002) estabelece a classificação com base nos objetivos gerais da pesquisa. O autor propõe três grandes grupos de pesquisas:

Exploratória: tem como objetivo proporcionar maior familiaridade com o problema, visando torná-lo mais claro ou constituir hipóteses, explorando problemas pouco conhecidos. Portanto, tem como característica marcante à flexibilidade no seu planejamento, de modo a possibilitar a consideração dos mais variados aspectos relativos ao objeto em estudo. Na maioria dos casos, esse tipo de pesquisa assume a 
forma de pesquisa bibliográfica ou de estudo de caso, envolvendo entrevistas com pessoas que tiveram experiência prática com o problema pesquisado e/ou análise de exemplos. Para Amicci (2004), um aspecto que impõe uma limitação aos estudos exploratórios é que eles:

não verificam, nem demonstram, mas tão somente conduzem a intuições ou hipóteses. Portanto, devem ser vistos como apenas um primeiro passo, requerendo estudos mais cuidadosamente controlados a fim de verificar se as hipóteses que surgem têm aplicabilidade geral. (AMICCI, 2004, p. 92).

- Descritiva: tem como objetivo descrever e entender o problema como um todo ou, então, estabelecer relações entre variáveis. Algumas pesquisas descritivas vão além da descoberta da relação entre as variáveis, servindo mais para proporcionar uma nova visão do problema, aproximando-as das pesquisas exploratórias. Segundo o autor:

As pesquisas descritivas são, juntamente com as exploratórias, as que
habitualmente realizam os pesquisadores sociais preocupados com a atuação
prática. São também as mais solicitadas por organizações como instituições
educacionais, empresas comerciais, partidos políticos, etc. (GIL, 2002, p. 42).

- Explicativa: também chamada de experimental, a pesquisa explicativa pretende dizer de que modo ou por que causas o fenômeno é produzido (CERVO e BERVIAN, 2002). Em outras palavras, procura explicar as relações de causa e efeito.

Gil (2002) acrescenta e destaca que a utilização da classificação acima exposta é muito útil para possibilitar uma aproximação conceitual. Contudo, para analisar os fatos do ponto de vista científico, confrontando a visão teórica com os dados da realidade, torna-se necessário traçar um modelo conceitual e operativo da pesquisa, algo como uma estratégia de pesquisa.

\subsection{ESTRATÉGIA DA PESQUISA}

O modelo conceitual e operativo da pesquisa, ao qual se refere a seção 3.3 (anterior), recebe o nome na língua inglesa de design, que pode ser traduzido para delineamento, pois visa expressar a idéia de modelo, sinopse e plano (YIN, 2005).

O delineamento refere-se ao que se pode chamar de planejamento estratégico de uma pesquisa. Este planejamento tem uma função ampla, envolvendo do desenho (diagramação, design), à previsão de análise e à interpretação dos dados coletados, 
considerando também, outros aspectos como o ambiente em que os dados são coletados e as formas de controle das variáveis envolvidas (GIL, 2002).

Dessa forma, o elemento mais importante para o planejamento estratégico de uma pesquisa, de acordo com Gil (2002), é o procedimento adotado para a coleta de dados. $\mathrm{O}$ autor define dois grandes grupos de procedimentos de coleta de dados:

Aqueles que utilizam as chamadas fontes de "papel" (pesquisa bibliográfica e documental); e,

- $\quad$ Aqueles cujos dados são fornecidos por pessoas (pesquisa experimental, levantamento - survey - e estudos de caso).

Além disso, Cervo e Bervian (2002) ressaltam que a pesquisa com tipo de investigação exploratória, independentemente da forma de abordagem ou da estratégia de pesquisa adotada, trabalha sobre os dados ou fatos colhidos no próprio ambiente do objeto pesquisado, portanto, a coleta de dados configura-se como uma atividade fundamental e de grande relevância para esse tipo de pesquisa. Entretanto, os autores ao discutirem sobre as pesquisas exploratórias, destacam que "essa pesquisa requer um planejamento bastante flexível para possibilitar a consideração dos mais diversos aspectos de um problema ou de uma situação". (CERVO e BERVIAN, 2002, p. 69).

Um dos grandes procedimentos de coleta de dados é a pesquisa bibliográfica, ou de fontes secundárias. Essa pesquisa, de acordo com Marconi e Lakatos (2003), envolve toda a bibliografia disponível já tornada pública, em relação ao tema estudado. Segundo Gil (2002), essa bibliografia disponível é constituída principalmente de livros e artigos científicos.

A principal fonte bibliográfica desta pesquisa, em função de abordar alguns temas que são atuais - estando ainda em debate ou em evolução -, constitui-se de artigos científicos publicados em periódicos, congressos, textos encontrados em dissertações, teses e sites da Internet. No entanto, os conceitos e temas já teorizados, têm como fontes de pesquisa os livros de diversos autores, os quais são geralmente debatidos a fim de enriquecer e fornecer maior embasamento teórico sobre o tema.

Outro grande procedimento de coleta de dados é o estudo de caso, que para Yin (2005) é considerado como uma estratégia de pesquisa abrangente, pois:

compreende um método que abrange tudo - tratando da lógica de planejamento, das técnicas de coleta de dados e das abordagens específicas à análise dos mesmos. Nesse sentido, o estudo de caso não é nem uma tática para a coleta de dados nem meramente uma característica do planejamento em si. (YIN, 2005, p. 33). 
De acordo com o autor, os estudos de caso são aplicados na tentativa de explicar ligações causais em intervenções ou situações da vida real que são complexas demais para tratamento através de estratégias experimentais ou de levantamento de dados (survey).

No entanto, com relação aos estudos de caso, especificamente, uma crítica freqüente é que eles fornecem pouca base para se fazer uma generalização. Yin (2005, p. 29) rebate estas críticas ao afirmar que os estudos de caso, "da mesma forma que os experimentos, são generalizáveis a proposições teóricas, e não a populações ou universos.".

Além disso, ao comparar o estudo de caso com o experimento, Yin (2005, p. 30) defende que o objetivo do pesquisador é "expandir e generalizar teorias (generalização analítica) e não enumerar freqüências (generalização estatística).”. O autor também defende que o estudo de caso é a estratégia de pesquisa ideal para responder a questões do tipo "como" e "por que" a respeito de um conjunto contemporâneo de acontecimento sobre o qual o pesquisador tem pouco ou nenhum controle.

Com relação a pouca robustez, usualmente associada ao resultado dos estudos de caso, Yin (2005) acredita que ela pode ser minimizada com os chamados "estudos de casos múltiplos", ou seja, projetos que embutem mais de um estudo de caso. Segundo o autor, a lógica que suporta este tipo de pesquisa é a lógica da replicação e não a da amostragem. Deste modo, a teoria é confrontada com os resultados de cada caso, de modo análogo com o que ocorre com os experimentos.

Cabe destacar ainda, de acordo com Freitas (2005, p. 62), a existência do tipo de estudo de caso exploratório, o qual "é uma abordagem teórica para o problema, explicando a causalidade e apresentando as ligações entre os objetos de estudo".

Diante do exposto, a cerca da importância da pesquisa bibliográfica e, principalmente, do estudo de caso, este trabalho optou por considerá-los como estratégias de pesquisa e não meros procedimentos de coleta de dados.

\subsection{CARACTERIZAÇÃO DA PESQUISA}

Baseado nas discussões das seções anteriores, esta pesquisa caracteriza-se:

- Com relação à sua abordagem, como qualitativa, tendo em vista o caráter de ciência social e a forma de tratar as questões que envolvem a problemática da pesquisa; 
- Com relação aos seus fins e à sua investigação, como exploratória, pois se busca a familiarização com o fenômeno estudado e/ou a obtenção de uma nova compreensão deste;

Com relação à estratégia de pesquisa propriamente dita, como bibliográfica e de estudos de casos múltiplos, visto que se pretende confrontar o referencial teórico pesquisado com o ambiente explorado, procurando-se evitar a ocorrência de excesso de formalismo (teorização sem a observação do real) e excesso de empirismo (observação do real sem teoria).

A Figura 9 (abaixo) foi elaborada como o objetivo de resumir e apresentar didaticamente os aspectos metodológicos adotados nesta pesquisa.

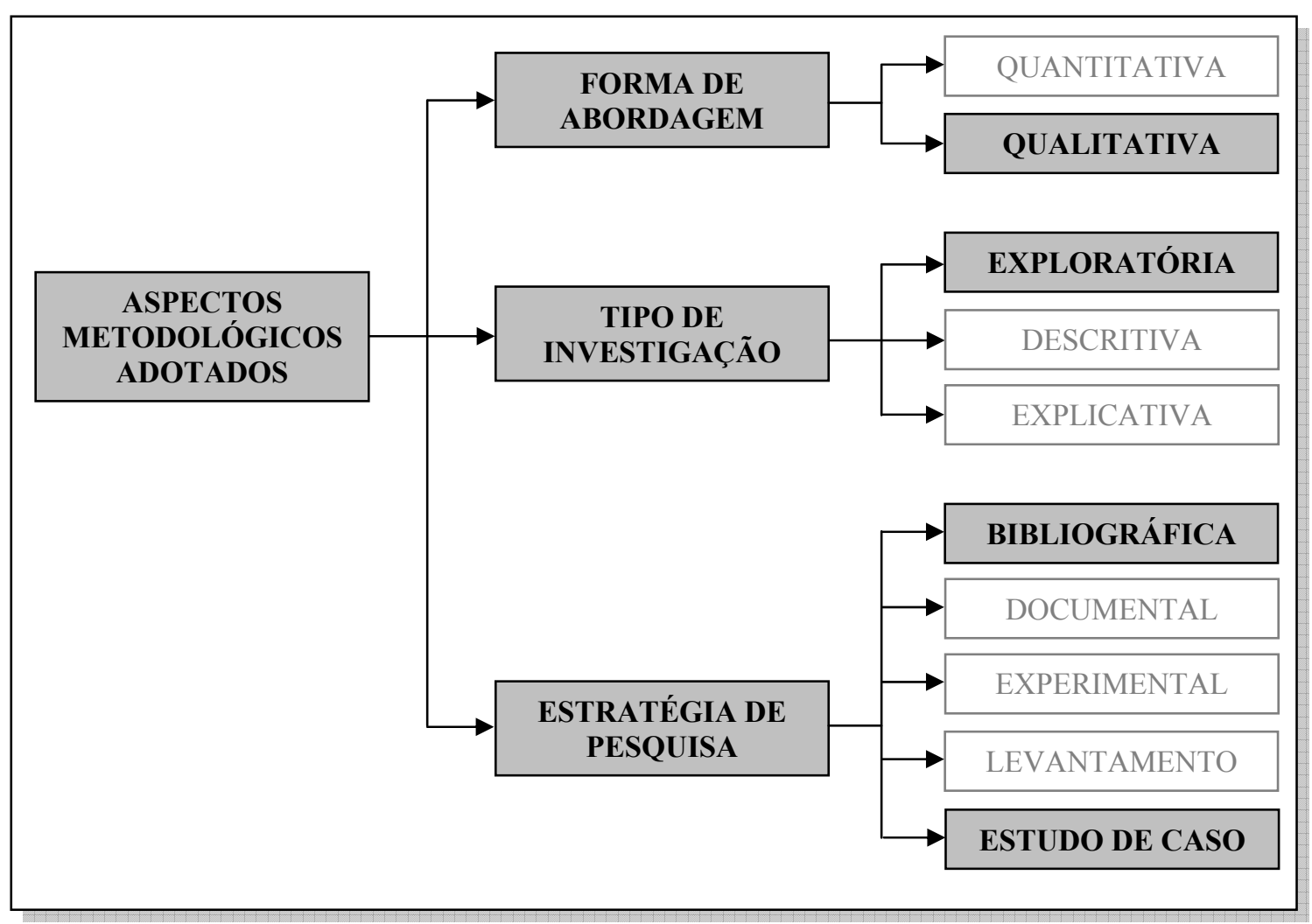

Figura 9 - Aspectos metodológicos adotados nesta pesquisa.

Fonte: elaboração própria a partir dos autores pesquisados.

\subsection{PLANEJAMENTO DO ESTUDO DE CASO}

Esta seção apresenta as etapas percorridas na fase de planejamento e projeto do estudo de casos múltiplos realizado durante o trabalho de campo desta pesquisa. 


\subsubsection{Universo da pesquisa}

O universo pesquisado é constituído por pequenas empresas (conforme critério definido na subseção 2.2.1) instaladas no município de Ribeirão Preto, ou nas cidades com no máximo cinqüenta quilômetros de distância deste centro.

É importante destacar que não se espera como resultado desta pesquisa, generalizações estatísticas acerca do universo pesquisado, haja vista que o objetivo do estudo é explorar uma realidade específica, confrontando o referencial teórico com o ambiente de campo pesquisado. Trata-se de um estudo exploratório, que busca conduzir apenas a intuições e/ou hipóteses.

\subsubsection{Definição da amostra da pesquisa}

De acordo com Amicci (2004), as pesquisas exploratórias devem apresentar variedade nos elementos estudados para permitir um maior aprendizado do tema.

Deste modo, o critério utilizado para definir a amostra desta pesquisa foi do tipo não probabilístico $\boldsymbol{e}$ intencional por conveniência, pois as empresas foram selecionadas de acordo com critérios pré-determinados.

Buscando garantir a qualidade dos resultados, a amostra desta pesquisa, ou segundo Yin (2005), unidades de caso, é constituída de três pequenas empresas, que foram selecionadas de acordo com os seguintes critérios:

- $\quad$ Ser uma pequena empresa, e não micro (vide critérios de definição na subseção 2.2.1);

- Representar os três segmentos de produção, ou seja, uma pequena empresa ser do comércio, outra da indústria e a última ser prestadora de serviços;

Possuir no mínimo, um microcomputador e ter instalado uma cópia de alguma destas ferramentas informatizadas: gerador de consulta ou de relatórios, algum software que utilize características OLAP, planilhas eletrônicas, navegador de Internet, gerenciador de correio eletrônico ou groupware.

\subsubsection{Questões da pesquisa}

Para Yin (2005, p. 26), definir as questões de pesquisa é "provavelmente o passo mais importante a ser considerado em um estudo de pesquisa". As questões de pesquisa 
representam o que o pesquisador deseja esclarecer, servindo de orientação para a condução do trabalho.

De acordo com Triviños (1992), as questões de pesquisa devem surgir das idéias colocadas na problemática e nos objetivos do trabalho.

Segundo Bigaton (2005), um meio de formular as questões de pesquisa de maneira mais precisa é através da revisão bibliográfica, a qual deve ser considerada um meio para atingir uma finalidade, e não uma finalidade em si.

Vindo ao encontro deste argumento, a revisão bibliográfica realizada nesta pesquisa mostrou que independentemente da ferramenta a ser analisada para apoiar a tomada de decisão nas pequenas empresas, é necessário que se considere a sua realidade, suas especificidades de gestão, e principalmente o processo decisório centrado na pessoa do proprietário-administrador.

Diante disto, para este trabalho, as seguintes questões de pesquisa foram formuladas:

- $\quad$ O tomador de decisão da pequena empresa utiliza de alguma ferramenta ou sistema informatizado para apoiar suas decisões?

- $\quad$ Se sim, quais são elas?

- $\quad$ Como estas ferramentas o apóiam em suas decisões?

- $\quad$ Existe algum fator de impedimento ou de incremento na utilização destas ferramentas, tendo em vista as particularidades de gestão e do processo decisório nestas empresas?

\subsubsection{Fatores qualitativos e pressupostos da pesquisa}

De acordo com Marconi e Lakatos (2002), hipótese é:

\footnotetext{
Uma proposição que se faz na tentativa de verificar a validade de resposta existente para um problema. É uma suposição que antecede a construção dos fatos e tem como característica uma formulação provisória; deve ser testada para determinar sua validade. Correta ou errada, de acordo ou contrária ao senso comum, a hipótese sempre conduz a uma verificação empírica. (MARCONI e LAKATOS, 2002, p. 28).
}

Entretanto, Tafner, Tafner e Fischer (1999), consideram que as hipóteses tratam os dados sob enfoque quantitativo, e os pressupostos apresentam características de uma hipótese qualitativa. Os autores concluem dizendo que o pressuposto é uma "hipótese 
cuja demonstração não dependerá de estatísticas ou rigorosas provas matemáticas (TAFNER, TAFNER e FISCHER, 1999, p. 42)".

Complementando, Cervo e Bervian (2002), definem a hipótese como uma resposta e explicação provisória, a qual relaciona duas ou mais variáveis.

Contudo, Tafner, Tafner e Fischer (1999), ressaltam que o pesquisador deve fazer uso de variáveis quando o trabalho envolve uma pesquisa quantitativa, e deve lançar mãos dos fatores qualitativos, quando a pesquisa abordar aspectos qualitativos.

Os autores definem que os fatores qualitativos de análise, exprimem os aspectos que deverão ser tratados de forma qualitativa na pesquisa. Ao passo, que as variáveis compreendem conceitos que "carregam, em si, os valores extraídos da hipótese, como quantidade, qualidade, magnitude, traços.” (TAFNER, TAFNER e FISCHER, 1999, p. 42).

Com base no tema desta pesquisa e fundamentado na discussão apresentada anteriormente, os fatores qualitativos (variáveis) de análise para este trabalho são:

- $\quad$ As pequenas empresas e suas particularidade de gestão;

- O processo decisório nas pequenas empresas;

- $\quad$ Os sistemas e as ferramentas de apoio à decisão.

De acordo com a questão formulada no problema de pesquisa, os seguintes pressupostos (hipóteses) foram identificados para este trabalho:

As pequenas empresas possuem particularidades de gestão que as diferenciam das grandes empresas, portanto requerem análises que considerem essa realidade (LEONE, 1999);

- Nas pequenas empresas o processo decisório está centrado na figura de seus proprietários, conseqüentemente quando se fala em apoio à decisão nestas empresas, é preciso explorar e analisar a relação destes com o ato de decidir (ZAMARIOLI, 2003);

- As organizações, inclusive as de pequeno porte, produzem diariamente dados operacionais sem contexto e dispersos pelo seu ambiente empresarial, portanto necessitam de ferramentas e sistemas computadorizados para auxiliá-las em seu processo decisório (ALBUQUERQUE, 2004; CAZARINI, 2002; MIGLIOLI, OSTANEL E TACHIBANA, 2004);

No entanto, as pequenas empresas são limitadas tecnológica e financeiramente para grandes investimentos em sistemas complexos de apoio à decisão 
(MORAIS, 1999), sendo necessário o estudo de ferramentas acessíveis à realidade destas empresas.

Diante destes pressupostos, torna-se fundamental explorar a relação entre os tomadores de decisão da pequena empresa (proprietários) com os possíveis sistemas ou ferramentas computacionais existentes em seus ambientes, de modo a analisar se existe alguma relação entre o processo de tomada de decisão e a utilização destes sistemas.

\subsubsection{Técnica de coleta de dados}

A coleta de dados para esta pesquisa foi realizada por meio de:

- Entrevistas semi-estruturadas, direcionadas por um roteiro base elaborado a partir da revisão bibliográfica. Cabe destacar que as entrevistas buscaram dar a oportunidade ao entrevistado de expressar suas opiniões a respeito do tema explorado;

Observações diretas realizadas no ambiente das pequenas empresas exploradas, a fim de identificar o modus operandi destas empresas com relação às questões da pesquisa;

- Exploração de artefatos físicos, que exemplificassem as respostas dos entrevistados, como por exemplo, a utilização de alguma ferramenta computadorizada ou de algum material impresso.

De acordo com Triviños (1992), a entrevista é importante, pois permite que sejam feitos questionamentos básicos apoiados em teorias, ao mesmo tempo em que permite o surgimento de novas questões, as quais vão surgindo conforme se recebem as respostas do informante.

Para Yin (2005), a entrevista é uma das mais importantes fontes de informações para um estudo de caso. Segundo o autor, é muito comum que as entrevistas para o estudo de caso sejam conduzidas de forma espontânea, pois dessa forma, o entrevistador pode tanto indagar o respondente quanto pedir a opinião dele sobre determinados eventos.

Essa forma espontânea de entrevistar, apontada por Yin (2005), foi utilizada nas explorações ao campo desta pesquisa. Notou-se com isso, certa facilidade na condução da entrevista, pois o entrevistado sentia-se à vontade para responder e apontar suas opiniões, sem a necessidade rígida de ficar preso às questões fechadas. 
Outra estratégia de coleta de dados adotada neste trabalho foram as observações diretas, que tiveram como base as reflexões do pesquisador durante as entrevistas. A adoção desta estratégia permitiu que alguns detalhes, que muitas vezes poderiam passar despercebidos pelo respondente, pudessem ser constatados.

Segundo Yin (2005, p. 120), as observações diretas configuram-se "como uma outra fonte de evidências em um estudo de caso". Para o autor, as observações podem variar de atividades formais (elaboração de protocolos de observação e verificação da incidência de certos tipos de comportamentos) a atividades informais.

No caso deste trabalho, as observações tiveram caráter informal, pois foram realizadas observações diretas ao longo das visitas de campo, incluindo naquelas ocasiões durante as quais estavam sendo coletadas outras evidências, como as evidências provenientes das entrevistas.

Além destas duas estratégias (entrevistas e observações), este trabalho adotou a exploração de artefatos físicos, que segundo Yin (2005, p. 124) pode ser "um aparelho de alta tecnologia, uma ferramenta ou instrumento, uma obra de arte ou alguma outra evidência física".

Os artefatos físicos explorados neste trabalho foram as ferramentas ou instrumentos computacionais mencionados e utilizados pelos entrevistados. Como exemplos, podem-se citar sites da Internet, relatórios ou consultas a sistemas de informação, planilhas eletrônicas, entre outras ferramentas tecnológicas.

\subsubsection{Técnica de análise dos dados}

Com relação à estratégia para se analisar os dados oriundos de estudos de caso, Yin (2005, p. 140-142) propõe três maneiras:

"Baseando-se em proposições teóricas": reflexão sobre o conjunto formado pelas questões de pesquisa, revisão da literatura e novas descobertas de pesquisa originadas das proposições teóricas. Estas proposições orientam a coleta e análise dos dados e contribuem para o entendimento da realidade, permitindo a análise do objeto estudado a partir de um referencial teórico estabelecido;

- "Pensando sobre explanações concorrentes": busca definir e testar explanações concorrentes. Essa estratégia pode ser relacionada à primeira, na medida em que as proposições teóricas originais talvez tenham incluído hipóteses concorrentes. 
No entanto, a estratégia é relevante mesmo na ausência dessas proposições teóricas e é especialmente útil ao se fazer avaliações do estudo de caso;

"Desenvolvendo uma descrição do caso": busca-se elaborar um referencial descritivo voltado à empresa em estudo, onde o observador objetiva apenas descrever a realidade ou quando não há alguma proposição teórica. Segundo o autor, é preferível utilizar proposições teóricas ou explanações concorrentes a utilizar essa estratégia.

A estratégia adotada por esta pesquisa para se analisar os dados dos estudos de caso é a do tipo “baseando-se em proposições teóricas” (YIN, 2005. p. 140), pois se buscou entender a realidade explorada a partir de referenciais teóricos pré-existentes.

\subsubsection{Estrutura para o relato do estudo de caso}

Baseado nas estruturas de relatórios de estudo de caso estudadas e corroborando com a sugestão proposta pelo orientador deste trabalho, a presente pesquisa optou pelo que Yin (2005, p. 178) considera como a "quarta modalidade" de relatório escrito.

Segundo o autor, esta modalidade de relatório aplica-se:

apenas a estudos de casos múltiplos. Nessa situação, não pode haver capítulos ou seções separados destinados a casos individuais. Em seu lugar, o relatório inteiro consiste em uma análise cruzada, mesmo que seja puramente descritivo ou que lide com tópicos explanatórios. (YIN, 2005. p. 178).

É importante destacar também, que o relato dos casos múltiplos desta pesquisa será no formato de apresentação de dados, acompanhado de análises e conclusões parciais, de modo a facilitar o encadeamento das idéias, bem como facilitar a sua leitura e compreensão. 


\section{CAPÍTULO 4 - TRABALHO DE CAMPO}

\subsection{REALIZAÇÃO DO TRABALHO}

O trabalho de campo desta pesquisa iniciou-se com visitas de apresentação em cinco pequenas empresas candidatas a serem as três unidades de caso deste estudo. Estas visitas ocorreram no final do segundo semestre de 2004, entre os meses de novembro e dezembro, com duração de no máximo trinta minutos cada uma.

A partir da análise da receptividade percebida nas visitas de apresentação, bem como baseado nos critérios de definição da amostra desta pesquisa (vide subseção 3.6.2), foram selecionadas três pequenas empresas para serem as candidatas a unidades de caso deste trabalho. Estas empresas foram novamente contatadas no início de 2005 a fim de solicitar a autorização de seus proprietários para que fizessem parte deste estudo.

Observou-se neste segundo contato, certa facilidade de acesso a estas empresas, pois se tratavam de locais onde o pesquisador já havia realizado uma visita preliminar de apresentação. Prova disso, foi a aceitação por parte destas empresas para serem as unidades de caso desta pesquisa.

Depois de confirmada a aceitação destas empresas em participar da pesquisa, foram realizadas algumas explorações observatórias, envolvendo as possíveis ferramentas computacionais existentes em seus ambientes. Tal exploração teve como objetivo subsidiar as entrevistas e observações a serem realizadas posteriormente com os proprietários destas pequenas empresas.

Estas explorações ocorreram durante o primeiro semestre de 2005 em duas das pequenas empresas. No segundo semestre de 2005, foi realizada a mesma exploração na terceira pequena empresa. Em média foram realizadas duas visitas em cada empresa, com duração de aproximadamente quatro horas cada.

Durante estas visitas de exploração inicial, buscou-se conhecer as ferramentas computacionais que por ventura os tomadores de decisão destas pequenas empresas utilizavam. Para isto, partiu-se da rotina do proprietário para, em alguns casos, observar o trabalho dos colaboradores auxiliares a ele. 
Após estas visitas de observação preliminar sobre a utilização de ferramentas computacionais no ambiente das pequenas empresas estudadas, o pesquisador partiu para a exploração própria destas ferramentas, a fim de tomar conhecimento das funcionalidades das mesmas, e também para enriquecer as entrevistas e observações que foram realizadas com os proprietários-administradores destas pequenas empresas.

Cabe destacar que nessa primeira observação não se buscou analisar a utilização de ferramentas que pudessem apoiar à tomada de decisão. Optou-se por uma exploração livre de todas as ferramentas computacionais presentes nestas empresas.

Como última fase das visitas de campo, realizou-se as entrevistas com os principais tomadores de decisão das pequenas empresas estudadas, ou seja, os seus proprietários. Estas entrevistas ocorreram no final de 2005, entre os meses de outubro e novembro. Cada entrevista/observação consumiu aproximadamente três horas de duração.

Durante todas as visitas e observações in locu nestas empresas (aproximadamente um total de vinte e cinco horas), buscou-se explorar o ambiente pesquisado com base nas variáveis desta pesquisa (subseção 3.6.4).

Além disso, as explorações, observações e entrevistas realizadas, orientaram-se pelas questões de pesquisa (vide subseção 3.6.3), as quais este trabalho busca esclarecer.

\subsection{DESCRIÇÃO DAS EMPRESAS ESTUDADAS}

O objetivo desta seção é descrever brevemente as três pequenas empresas participantes desta pesquisa, as quais foram identificadas como empresas C, I e S, por serem as iniciais do segmento de produção ao qual pertencem, ou seja, comércio, indústria e serviços; as mesmas serão apresentadas pela ordem alfabética de suas iniciais.

A descrição destas empresas foi realizada com base nas informações obtidas nas visitas de observação, durante as entrevistas com os proprietários-administradores e em seus sites na Internet.

\subsubsection{Empresa C}

A empresa C foi fundada em 1999, no município de Ribeirão Preto, estado de São Paulo, por um casal de sócios, onde o esposo configura-se como o administrador 
central da empresa, e sua e esposa como responsável pela área administrativa e financeira.

A empresa atua no ramo de comercialização e distribuição de livros e materiais educacionais de duas editoras nacionais. O raio de atuação da empresa é formado por uma região composta por municípios do norte do estado de São Paulo e alguns municípios do sul do estado de Minas Gerais.

O sócio-administrador era funcionário de uma das editoras que hoje representa e recebeu a proposta para ser seu distribuidor na região de Ribeirão Preto, surgindo assim, a empresa C.

Os principais produtos que a empresa comercializa são os livros e materiais educacionais das duas editoras que distribui, pois se trata de uma representação exclusiva, não permitindo à empresa $\mathrm{C}$ revender produtos de outras editoras. A divulgação destes produtos fica a cargo de uma equipe de funcionários das editoras representadas.

Em função do tipo de produto comercializado pela empresa $C$, seus principais clientes são escolas, professores, livrarias e alunos em geral.

A empresa tem um quadro de aproximadamente quinze funcionários, pois oscila para mais e para menos dependendo da época do ano (sazonalidade de vendas).

\subsubsection{Empresa I}

A empresa I iniciou suas atividades em 1993, no município de Cravinhos, estado de São Paulo, por um ex-funcionário de uma grande empresa da região. A exemplo da empresa C, esta empresa é formada por um casal de sócios, onde o esposo configura-se como o administrador central da empresa, voltado muito para a área comercial e produtiva, e sua esposa como responsável pela área administrativa e financeira.

A empresa atua no ramo de industrialização de materiais elétricos, e comercializa com todas as regiões do Brasil através de seus representantes, realizando algumas vendas diretas apenas para clientes de grande porte.

Os principais produtos que a empresa fabrica são materiais elétricos para concessionárias de energia e terminais elétricos automotivos.

Em função do tipo de produto industrializado, a empresa I tem como principais clientes as empresas do setor automotivo (fornecedores de peças e montadoras de automóveis) e de distribuição de energia elétrica (concessionárias). 
A empresa tem um quadro de aproximadamente noventa funcionários, sobretudo na área produtiva.

\subsubsection{Empresa $S$}

A empresa $\mathrm{S}$ iniciou suas atividades no ano de 2000, no município de Jaboticabal, estado de São Paulo, por dois ex-funcionários de uma grande empresa da região. Em meados de 2002, os dois sócios resolveram desfazer a sociedade, e a empresa foi dividida em duas, onde a empresa $\mathrm{S}$ mudou-se para Ribeirão Preto, em busca de novos mercados e oportunidades.

Esta empresa é formada por apenas um sócio, que assume o papel de diretor geral da empresa, com atividades voltadas para a área estratégica e comercial.

A empresa atua no ramo de prestação de serviços de consultoria empresarial, e tem como raio de atuação cidades com aproximadamente trezentos quilômetros de distância de sua sede.

Os principais produtos/serviços que a empresa comercializa são projetos de consultoria empresarial voltados para as várias áreas da administração.

A empresa $\mathrm{S}$, diferentemente das empresas $\mathrm{C}$ e I, tem como clientes qualquer empresa de seu raio de atuação que esteja interessada em seus serviços. No entanto, observou-se que grande parte de seus clientes são do setor industrial.

A empresa tem um quadro de aproximadamente vinte colaboradores, entre funcionários e consultores.

\subsection{APRESENTAÇÃO E ANÁLISE DOS DADOS}

O objetivo desta seção é apresentar e analisar os dados coletados nas três pequenas empresas pesquisadas (unidades de caso).

Esta seção, e todo o trabalho de campo, basearam-se nas variáveis:

- $\quad$ As especificidades de gestão das pequenas empresas;

- Seu processo decisório e suas particularidades;

- $\quad$ A presença de sistemas e ferramentas computacionais de apoio à decisão.

Bem como nas questões desta pesquisa:

- $\quad$ O tomador de decisão da pequena empresa utiliza de alguma ferramenta ou sistema informatizado para apoiar suas decisões?

- $\quad$ Se sim, quais são elas? 
- $\quad$ Como estas ferramentas o apóiam em suas decisões?

- $\quad$ Existe algum fator de impedimento ou de incremento na utilização destas ferramentas, tendo em vista as particularidades de gestão e do processo decisório nestas empresas?

Nas próximas subseções, onde são apresentados e analisados os dados da pesquisa de campo deste trabalho, o texto foi organizado de modo a facilitar a reflexão acerca das questões desta pesquisa. Dessa maneira, as subseções obedecem à seguinte estrutura:

O tomador de decisão da PE e as ferramentas de apoio à decisão: compreende a apresentação e análise dos dados sobre as ferramentas encontradas e utilizadas pelo tomador de decisão, bem como a maneira como eles as auxiliam;

- $\quad$ As particularidades da PE e as ferramentas de apoio à decisão: refere-se à apresentação e análise dos dados de acordo com algumas das particularidades de gestão da pequena empresa, as quais por ventura possam influenciar na utilização das ferramentas informatizadas de apoio à decisão.

\subsection{1 $O$ tomador de decisão da PE e as ferramentas de apoio à decisão}

Nas três empresas estudadas, foi possível identificar a presença e a utilização de ferramentas informatizadas que permitem ao proprietário-administrador interagir com as algumas das principais informações dos seus respectivos ambientes externos. São elas:

- $\quad$ Navegador de Internet: muito utilizado pelas empresas C e S; utilização média pela empresa I;

- $\quad$ Site próprio: muito utilizado pela empresas $\mathrm{C}$;

- $\quad$ Gerenciador de correio eletrônico: muito utilizado pelas três empresas;

- Comunicador instantâneo: muito utilizado pela empresa S; utilização média pela empresa $\mathrm{C}$ e baixa ou nenhuma utilização pela empresa I.

Quando indagados sobre a utilização destas ferramentas para apoiar às suas decisões, os proprietários das três pequenas empresas mostraram interesses diferentes.

O Quadro 6, abaixo, resume os principais dados coletados junto às três empresas pesquisadas, no tocante à relação entre o tomador de decisão e as ferramentas de apoio à decisão para manipular informações do ambiente externo. Estes dados são explicados de forma detalhada na seqüência do quadro. 


\begin{tabular}{|c|c|c|c|}
\hline Casos & Ferramentas utilizadas & Grau de utilização & Interesses e preocupações \\
\hline \multirow{3}{*}{$\mathbf{C}$} & Navegador de Internet & Alto & \multirow{3}{*}{$\begin{array}{l}\text { - Conhecer mudanças no seu setor; } \\
\text { - Formular estratégias; } \\
\text { - Antecipar ações de curto prazo. }\end{array}$} \\
\hline & Site próprio & Alto & \\
\hline & Correio eletrônico & Alto & \\
\hline \multirow{3}{*}{ I } & Navegador de Internet & Médio & \multirow{3}{*}{$\begin{array}{l}\text { - Preocupação em monitorar o ambiente } \\
\text { externo, mas baixa utilização das } \\
\text { ferramentas informatizadas. }\end{array}$} \\
\hline & Site próprio & Baixo & \\
\hline & Correio eletrônico & Médio & \\
\hline \multirow{3}{*}{$\mathbf{S}$} & Navegador de Internet & Alto & \multirow{3}{*}{$\begin{array}{l}\text { - Monitorar ações da concorrência e de } \\
\text { seus clientes; } \\
\text { - Traçar planos comerciais e estratégicos; } \\
\text { - Diminuir custos operacionais. }\end{array}$} \\
\hline & Site próprio & Baixo & \\
\hline & Correio eletrônico & Alto & \\
\hline
\end{tabular}

Quadro 6 - O tomador de decisão das PEs e as ferramentas de apoio à decisão (informações externas).

Para o tomador de decisão da empresa $\mathrm{C}$, as informações sobre o seu ambiente externo devem ser constantemente consultadas. Um dos principais motivos desta preocupação, segundo o proprietário desta empresa, está na necessidade de conhecer rapidamente as mudanças no seu setor que possam por ventura, interferir em seus negócios. De acordo com ele, a sua empresa é influenciada por mudanças em leis e políticas educacionais.

O proprietário da empresa $\mathrm{C}$ destacou e explicou como acontece na sua empresa a utilização das seguintes ferramentas relacionadas à Internet e ao correio eletrônico:

Notícias recebidas através de e-mail, no formato de newsletters: são notícias oriundas de órgãos confiáveis, como por exemplo, associações de classes relacionadas às editoras, livrarias e ao mercado editorial em geral. Além disso, algumas dessas newsletters funcionam como uma espécie de resumo das notícias dos principais jornais do Brasil;

Um site, no formato de um portal corporativo das editoras que ele representa, com informações sobre o andamento de seus pedidos, bem como, posição de produtos em falta e a previsão de recebimento de mercadorias;

- Comunicador instantâneo MSN Messenger: utilizado pelo proprietário para se comunicar com alguns funcionários do seu fornecedor e demais distribuidores espalhados pelo país.

Além destas ferramentas, a empresa $\mathrm{C}$ possui um site próprio na Internet onde realiza vendas e recebe contatos de seus clientes. Pelo que pôde ser observado, o site da empresa ainda não gera muitas informações que possam embasar a tomada de decisão do seu proprietário. Segundo ele, a informação mais utilizada do site diz respeito ao 
conteúdo das mensagens postadas pelos clientes, a fim de analisar reclamações ou oportunidades de melhorias.

Quando questionado sobre se essas ferramentas o apóiam em suas decisões, ele respondeu dizendo que faz uso das informações originadas destas ferramentas para formular estratégias de negócios, bem como, antecipar ações emergenciais de curto prazo. Isto pode ser observado durante as visitas, pois o tomador de decisão consultava constantemente as notícias recebidas e o portal corporativo mencionado anteriormente.

Observou-se durante as entrevistas e explorações que o proprietário da empresa $\underline{\mathrm{C}}$ tem certa familiaridade com o ambiente da Internet, utilizando-a com freqüência. Além disso, sua empresa tem uma boa infra-estrutura tecnológica, possuindo um notebook em sua mesa e acesso à Internet de alta velocidade.

No caso da empresa $S$, pode-se perceber também a importância atribuída à interação com o ambiente externo. De acordo com seu proprietário-administrador, um dos principais motivos que o leva a monitorar as informações deste ambiente, é a sua preocupação com seus clientes e com a concorrência. Segundo ele, sua empresa busca estar presente junto aos clientes, para criar um vínculo duradouro e proporcionar condições de se oferecer novos e melhores serviços.

Já com relação à concorrência, o proprietário-administrador da empresa $\mathrm{S}$ tem a preocupação de monitorar ao máximo os acontecimentos que envolvem os seus principais concorrentes. Dessa forma, segundo ele é possível estar à frente de seus concorrentes.

Para acompanhar as informações de seu ambiente externo, o proprietárioadministrador da empresa $\mathrm{S}$ utiliza das seguintes ferramentas:

Navegador de Internet para acessar portais de notícias, onde obtém informações relacionadas à economia, governo, fusões entre empresas;

- $\quad$ Buscas em sites de empresas em geral: monitora e busca informações sobre empresas que podem ser prospectadas por seu setor comercial, além de acessar as informações relacionadas aos seus clientes;

- Comunicador instantâneo MSN Messenger: utiliza esta ferramenta para tratar com seus clientes atuais ou potenciais; relacionar-se com parceiros e pessoas chaves fornecedoras de informações importantes.

O proprietário-administrador dessa empresa, como o da empresa $\mathrm{C}$, também possui um notebook em sua mesa, porém acessa as informações em menor freqüência ao longo do dia, tendo em vista que realiza trabalhos externos. 
Quando questionado sobre de que forma essas ferramentas o apóiam em suas decisões, ele destacou o uso destas ferramentas para agilizar alguma ação, bem como traçar algum plano comercial e estratégico, ou mesmo para implantar meios de diminuir os custos operacionais (ligações telefônicas, por exemplo).

$\mathrm{O}$ tomador de decisão da empresa $\mathrm{S}$ também tem facilidade de manuseio destas ferramentas, e sua empresa possui uma boa infra-estrutura tecnológica, com acesso à Internet de alta velocidade.

$\mathrm{Na}$ empresa I, apesar do proprietário-administrador considerar importante o monitoramento das informações do ambiente externo, não se observou uma forte utilização de ferramentas informatizadas para tal finalidade.

As ferramentas apontadas pelos proprietários das empresas C e S , também foram observadas na empresa I, entretanto sua utilização foi considerada pelo seu proprietário como não voltada para o apoio à decisão. As ferramentas utilizadas na empresa I para interagir com o ambiente externo são:

- $\quad$ Navegador de Internet;

- $\quad$ Gerenciador de correio eletrônico.

Observou-se que o proprietário-administrador da empresa I não tem muita familiaridade com os recursos da tecnologia da informação. Isso pode ser considerado como um dos motivos da baixa utilização e exploração destes recursos.

O Quadro 7, abaixo, resume a infra-estrutura tecnológica e a facilidade do tomador de decisão em manipular as ferramentas informatizadas apresentadas.

\begin{tabular}{|c|c|c|}
\hline Casos & Infra-estrutura tecnológica & Facilidade de manipular as ferramentas \\
\hline $\mathbf{C}$ & $\begin{array}{c}\text { Boa infra-estrutura } \\
\text { Presença de notebooks } \\
\text { Acesso à Internet de alta velocidade }\end{array}$ & Grande \\
\hline I & $\begin{array}{c}\text { Infra-estrutura mediana } \\
\text { Presença de notebooks } \\
\text { Acesso à Internet de alta velocidade }\end{array}$ & Média / baixa \\
\hline S & $\begin{array}{c}\text { Infra-estrutura mediana } \\
\text { Presença de notebooks } \\
\text { Acesso à Internet de alta velocidade }\end{array}$ & Grande \\
\hline
\end{tabular}

Quadro 7 - Infra-estrutura tecnológica e facilidade do tomador de decisão manipular as ferramentas.

Uma característica peculiar observada na empresa I foi a grande presença de softwares de código aberto, ou seja, livres de pagamento de licença de uso. Ao ser questionado sobre o motivo da adoção desses aplicativos, o seu proprietário- 
administrador revelou ser em função de autuação recebida dos órgãos de repressão à pirataria, e não por estratégia própria.

Com relação à presença e à utilização de ferramentas informatizadas que permitam ao proprietário-administrador interagir com algumas das principais informações dos seus respectivos ambientes internos, observou-se nas três empresas estudas as seguintes ferramentas:

- $\quad$ Sistema integrado de gestão (ERP);

- Planilhas eletrônicas;

- $\quad$ Aplicativo para colaboração de grupos (groupware).

No entanto, ao se observar a interação dos tomadores de decisão das três empresas com as informações dos seus ambientes internos, a realidade mostrou-se um pouco diferente entre as empresas.

O Quadro 8, abaixo, resume os principais dados coletados junto às três empresas pesquisadas, no tocante à relação entre o tomador de decisão e as ferramentas de apoio à decisão para manipular informações do ambiente interno. Estes dados são explicados de forma detalhada na seqüência do quadro.

\begin{tabular}{|c|c|c|l|}
\hline Casos & Ferramentas utilizadas & Grau de utilização & \multicolumn{1}{|c|}{ Motivos } \\
\hline \multirow{2}{*}{ C } & ERP & Médio & $\begin{array}{l}\text { - Desconhecimento das potencialidades } \\
\text { do ERP. }\end{array}$ \\
\cline { 2 - 4 } & Planilhas eletrônicas & Médio & - Atividades operacionais. \\
\hline \multirow{2}{*}{ I } & ERP & Baixo & $\begin{array}{l}\text { - Desconhecimento das potencialidades } \\
\text { do ERP. }\end{array}$ \\
\cline { 2 - 4 } & Planilhas eletrônicas & Alto & $\begin{array}{l}\text { - Necessidade de acompanhar a produção } \\
\text { e seu desempenho. }\end{array}$ \\
\hline \multirow{2}{*}{ S } & ERP & Baixo & $\begin{array}{l}\text { - Limitação do ERP quanto aos recursos } \\
\text { de apoio à decisão. }\end{array}$ \\
\cline { 2 - 4 } & Groupware & Alto & $\begin{array}{l}\text { - Ferramenta open source que controla a } \\
\text { capacidade produtiva. }\end{array}$ \\
\hline
\end{tabular}

Quadro 8-O tomador de decisão das PEs e as ferramentas de apoio à decisão (informações internas).

As empresas C e I possuem sistemas integrados de gestão (ERP), porém ambos estão recém implantados e de forma incompleta, ou seja, nem todas as áreas funcionais destas empresas estão informatizadas. Com isso, os tomadores de decisão destas empresas desconhecem muitas potencialidades de seus sistemas.

Isto pôde ser constatado durante as entrevistas, pelo desconhecido que os proprietários-administradores possuem acerca da existência nesses sistemas de ferramentas de geração de relatórios e de consultas personalizadas. 
No caso da empresa $S$, o seu sistema de informação é limitado quanto aos recursos de apoio à decisão, sendo considerado pelo proprietário-administrador como uma ferramenta para a realização de atividades operacionais.

Nas empresas C e I, os seus proprietários disseram utilizar-se de informações originadas do ERP para tomar decisões com relações ao ambiente interno (volume de vendas, posição de estoque, pedidos em aberto, entre outras informações).

No caso específico da empresa $\mathrm{C}$, o tomador de decisão relatou buscar em alguns relatórios do ERP informações para analisar e acompanhar o seu volume de vendas. No entanto, estas informações são tratadas manualmente, sem o auxílio de nenhuma ferramenta computadorizada.

A utilização das planilhas eletrônicas foi observada nas três empresas. Contudo na empresa I a sua utilização foi a mais voltada para o suporte à decisão do proprietárioadministrador.

O tomador de decisão desta empresa, por tratar-se de uma indústria, precisava de alguns indicadores que fornecessem informações sobre a produtividade do setor produtivo mais importante desta empresa. A empresa, através de apontamentos manuais, sempre coletou os dados. Entretanto, estes dados não eram organizados e trabalhados de forma a fornecer informações relevantes. Com a contratação de um estagiário em engenharia de produção, a pequena empresa passou a dispor de um profissional que pudesse organizar e tratar os dados coletados na produção.

Estes dados são organizados em planilhas eletrônicas do Open Office (software de código livre), e a partir deles são gerados relatórios para os principais tomadores de decisão da área industrial, que são o proprietário-administrador e o encarregado da produção. As principais informações destas planilhas são relacionadas ao índice de produtividade e de refugo de cada funcionário ao longo dos dias do mês.

Ao explorar estas planilhas e relatórios, notou-se a presença marcante de gráficos, apontado pelo tomador de decisão desta empresa, como uma forma agradável e prática de se analisar dados para a tomada de decisão.

Ao questionar o tomador de decisão da empresa I sobre de que forma essas planilhas o apóiam em suas decisões, ele destacou o uso destas ferramentas em importantes decisões tomadas recentemente, as quais foram principalmente:

- $\quad$ Remunerar de forma extra os funcionários da fábrica de acordo com a sua produtividade; 
- $\quad$ Espalhar ao longo da empresa, principalmente no chão de fábrica, cópias destas planilhas de modo a incentivar os funcionários a serem mais produtivos.

O proprietário-administrador, durante a entrevista, destacou a importância de se trabalhar com estas informações, pois a partir delas ele consegue acompanhar periodicamente o índice de produtividade de um setor essencial para a sua empresa. Com base nas informações destas planilhas o tomador de decisão da empresa I decidiu manter apenas um turno de produção, incentivando o aumento da produtividade e a diminuição do desperdício.

Um ponto importante a ser destacado na empresa I, é que o tomador de decisão não manipula diretamente os dados destas planilhas, e sim os recebe no formato de relatórios impressos preparados por um estagiário. O motivo relatado por ele para não manipular os dados diretamente nas planilhas é o desconhecimento da utilização da ferramenta.

$\mathrm{Na}$ empresa $\mathrm{C}$, o proprietário-administrador relatou que existem alguns controles fundamentais executados em planilhas eletrônicas, neste caso, no MS-Excel. Estes controles são relacionados à área financeira, como por exemplo, o fluxo de caixa da empresa.

Segundo o proprietário desta empresa, a planilha específica de fluxo de caixa (uma das informações mais consultadas por ele), fornece informações importantes sobre a situação financeira da empresa. O tomador de decisão da empresa C utiliza essa planilha para subsidiar alguma decisão que envolva investimentos ou desencaixes financeiros.

No entanto, ao observar-se a utilização desta planilha, percebeu-se que ela é muito utilizada em função da sua facilidade e flexibilidade, pois o sistema de informação integrado da empresa possui as mesmas informações, mas de uma forma mais complexa e não flexível, segundo o tomador de decisão.

Além disso, na empresa $\mathrm{C}$, como ocorre na empresa I, o tratamento dos dados destas planilhas é realizada por algum auxiliar ao tomador de decisão, e não ele próprio. O motivo relatado por ele para não manipular os dados diretamente nas planilhas, também é o desconhecimento da utilização da ferramenta.

No caso da empresa $\mathrm{S}$, durante as observações realizadas in locu, pode-se constatar a utilização, principalmente por parte do tomador de decisão, de uma ferramenta de colaboração de trabalho em grupo, ou simplesmente, groupware. 
O proprietário-administrador desta empresa, por tratar-se de uma empresa de serviços de consultoria, buscou durante muito tempo alguma ferramenta informatizada que fornecesse condições para que os seus consultores pudessem colaborar atividades e trabalhos em comum. Segundo ele, somente a partir da contratação de um profissional dedicado para a área de tecnologia da informação, foi possível encontrar tal ferramenta.

A ferramenta encontrada, chamada Group Office, é de código aberto, ou seja, livre de pagamento de licença de uso, e flexível o bastante para ser traduzida e ajustada para algumas das necessidades da empresa. O endereço na Internet desta ferramenta, segundo o tomador de decisão é www.group-office.com.

O proprietário-administrador da empresa $\mathrm{S}$ decidiu iniciar a utilização desta ferramenta pela agenda corporativa compartilhada, pois uma de suas maiores dificuldades, por lidar com vários consultores, é saber quando o consultor está disponível ou ocupado.

Além dessa funcionalidade, o tomador de decisão desta empresa revelou e demonstrou, através da ferramenta, outras funcionalidades que em breve serão implantadas e passarão a fazer parte da sua rotina de trabalho:

- $\quad$ Envio e recebimento de e-mails;

- Compartilhamento de arquivos;

- Uma espécie de compartilhamento de projetos de trabalhos, onde uma pessoa pode ser alocada para determinado projeto, em determinado dia e horário;

- Gerenciador de tarefas compartilhado.

Ao indagar o tomador de decisão da empresa $\mathrm{S}$ sobre de que forma a ferramenta de groupware passou a apoiar as suas decisões, ele destacou a facilidade e agilidade em que consegue saber onde um recurso produtivo de sua empresa (o consultor) está alocado. Essa informação, segundo ele, lhe permite tomar decisões como:

- Mudar um plano de divulgação comercial para determinado projeto em função de o consultor estar ocupado; ou o contrário,

- Verificar a disponibilidade de trabalho de algum consultor para tentar fechar algum novo negócio.

O proprietário-administrador da empresa S destacou a importância de se analisar estas informações para se conhecer a real capacidade de trabalho que sua empresa pode oferecer ao mercado, bem como, verificar as áreas que necessitam de contratação de novos consultores. 


\subsubsection{As particularidades da $\mathrm{PE}$ e as ferramentas de apoio à decisão}

Nas três empresas pesquisadas notou-se a presença de algumas das especificidades de gestão comumente encontradas nas pequenas empresas, e discutidas na revisão bibliográfica (vide subseção 2.2.4).

No entanto, cabe destacar que o propósito deste trabalho não é discorrer sobre as especificidades das pequenas empresas pesquisadas, mas sim, analisar se existe alguma particularidade destas empresas que impeça ou incremente a utilização de ferramentas computacionais de apoio à decisão.

As três empresas pesquisadas têm como característica comum a presença e a participação do proprietário-administrador nos seus processos decisórios.

No entanto, na empresa I, por possuir uma estrutura organizacional mais formalizada do que as outras duas, o proprietário-administrador participa mais de decisões de nível tático e estratégico, e seus supervisores de área tratam das decisões operacionais não críticas. No caso de decisões críticas, mesmo que operacionais, o proprietário desta empresa é comunicado e participado.

Os proprietários das empresas $\mathrm{C}$ e $\mathrm{S}$ declararam possuir um estilo democrático de tomar decisões, buscando informações e ajuda de outros colaboradores. No entanto, os mesmos deixaram claro em outros momentos da entrevista, que buscam saber de todas as decisões que ocorrem em suas empresas, sejam elas operacionais, táticas ou estratégicas.

A centralização na tomada de decisão observada nas três empresas pesquisadas vai de encontro com o levantamento bibliográfico realizado e revela um aspecto importante no tratamento das informações para a tomada de decisão nestas empresas, conforme pode ser observado nas informações do Quadro 9, abaixo.

\begin{tabular}{|c|c|c|c|}
\hline Casos & $\begin{array}{c}\text { Centralização das } \\
\text { decisões no proprietário }\end{array}$ & $\begin{array}{c}\text { Quem prepara / } \\
\text { manipula as } \\
\text { informações }\end{array}$ & $\begin{array}{c}\text { Motivos de não preparar / manipular } \\
\text { as informações }\end{array}$ \\
\hline C & Grande & $\begin{array}{c}\text { O próprio tomador } \\
\text { de decisões. } \\
\text { Funcionários. }\end{array}$ & Falta de tempo. \\
\hline I & Média & Funcionários & $\begin{array}{c}\text { Dificuldade de manuseio das } \\
\text { ferramentas. }\end{array}$ \\
\hline S & Grande & $\begin{array}{c}\text { O próprio tomador } \\
\text { de decisões. } \\
\text { Funcionários }\end{array}$ & Desconhecimento das ferramentas. \\
\hline
\end{tabular}

Quadro 9 - Particularidades das PEs e as ferramentas de apoio à decisão. 
Nas três empresas pesquisadas existe a figura de um ou mais colaboradores que tratam os dados de forma a facilitar a interpretação e análise das informações pelo tomador de decisão. Esse tratamento se dá na forma da preparação de um relatório, de uma planilha eletrônica, e em alguns casos, como na empresa I, na manipulação dos dados propriamente dita.

Ao serem questionados sobre o motivo pelo qual não utilizam diretamente as ferramentas computacionais, as respostas foram basicamente as mesmas, ou seja, a falta de tempo, a dificuldade no manuseio, e muitas vezes desconhecimento da ferramenta.

O Quadro 10, abaixo, relaciona o grau de utilização das ferramentas informatizadas com a facilidade que os tomadores de decisão têm para manipulá-las, demonstrando que nas empresas onde o tomador de decisão tem maior facilidade de operação das ferramentas, a sua utilização é mais efetiva.

\begin{tabular}{|c|c|c|l|}
\hline Casos & Ferramentas utilizadas & Grau de utilização & \multicolumn{1}{|c|}{ Motivos } \\
\hline \multirow{2}{*}{ C } & ERP & Médio & $\begin{array}{l}\text { - Desconhecimento das potencialidades } \\
\text { do ERP. }\end{array}$ \\
\cline { 2 - 4 } & Planilhas eletrônicas & Médio & - Atividades operacionais. \\
\hline \multirow{2}{*}{ I } & ERP & Baixo & $\begin{array}{l}\text { - Desconhecimento das potencialidades } \\
\text { do ERP. }\end{array}$ \\
\cline { 2 - 4 } & Planilhas eletrônicas & Alto & $\begin{array}{l}\text { - Necessidade de acompanhar a produção } \\
\text { e seu desempenho. }\end{array}$ \\
\hline \multirow{2}{*}{ S } & ERP & Baixo & $\begin{array}{l}\text { - Limitação do ERP quanto aos recursos } \\
\text { de apoio à decisão. }\end{array}$ \\
\cline { 2 - 4 } & Groupware & Alto & $\begin{array}{l}\text { - Ferramenta open source que controla a } \\
\text { capacidade produtiva. }\end{array}$ \\
\hline
\end{tabular}

Quadro 10 - Grau de utilização das ferramentas X facilidade de manipulá-las.

Este cenário mostra a importância de se trabalhar o treinamento dos proprietários-administradores quanto ao uso destas ferramentas, mostrando suas potencialidades e vencendo as barreiras quanto ao uso.

Além disso, de acordo com as respostas dos proprietários-administradores, as ferramentas de apoio à decisão que desejam voltar-se para o público das pequenas empresas, devem primar pela facilidade e flexibilidade de utilização. 


\section{CAPÍTULO 5 - CONCLUSÕES}

\subsection{CONSIDERAÇÕES FINAIS}

A proposta desta pesquisa foi a de estudar de que forma as ferramentas ou sistemas informatizados de apoio à decisão podem auxiliar os tomadores de decisão das pequenas empresas, considerando as suas especificidades de gestão, bem como o seu processo de decisão baseado na figura do proprietário-administrador.

Para alcançar este objetivo, num primeiro momento, através de uma extensa pesquisa bibliográfica, foram levantadas as informações necessárias para embasar teoricamente o trabalho acerca das suas variáveis, ou seja, as pequenas empresas e suas particularidade de gestão, o processo decisório nestas empresas, os sistemas e ferramentas informatizadas de apoio à decisão.

Após esta etapa, iniciaram-se os estudos exploratórios de campo, direcionados pela estratégia de estudos múltiplos de casos. Para isso, foram selecionadas três pequenas empresas na região de Ribeirão Preto, que atendessem aos critérios definidos para a seleção da amostra da pesquisa. Como forma de enriquecer o estudo de casos, optou-se por escolher uma pequena empresa de cada setor produto, ou seja, comércio, indústria e de serviços.

O propósito principal de se explorar os estudos de casos desta pesquisa foi o de analisar dentro da realidade da pequena empresa, a presença ou a ausência de possíveis ferramentas informatizadas de apoio à decisão, bem como, entender a maneira como o principal tomador de decisão destas empresas (proprietário-administrador) utiliza e se beneficia de tais ferramentas. Estes estudos foram subsidiados pelo conhecimento formulado durante a revisão da literatura pertinente.

Os dados coletados e analisados permitem que se teçam alguns comentários finais sobre as variáveis de pesquisa estudadas nas três pequenas empresas da região de Ribeirão Preto. Comentários estes, fundamentados à luz das questões e da problemática proposta para esta pesquisa. 
Com relação à presença de ferramentas informatizadas que possam apoiar às decisões, pode-se dizer que as três empresas pesquisadas possuem pelo menos uma das ferramentas listadas abaixo. Elas foram organizadas em dois blocos, sendo as externas, quando o tomador de decisão as utiliza predominantemente para manipular informações do ambiente externo e as internas, quando são para informações predominantes do ambiente interno.

- Externas: navegador de Internet, gerenciador de correio eletrônico e comunicador instantâneo;

- Internas: sistema integrado de gestão (ERP), planilhas eletrônicas e aplicativo para colaboração de grupos (groupware).

No entanto, conforme destacado na revisão teórica e constatado nos estudos de casos, a figura do proprietário-administrador exerce forte influência nas decisões destas empresas.

Essa especificidade presente nas pequenas empresas leva a uma consideração importante quanto ao uso das ferramentas informatizadas de apoio à decisão nestas empresas. Pode-se dizer que nas empresas onde o proprietário-administrador tem maior familiaridade com a tecnologia da informação, a utilização de tais ferramentas caracterizou-se como auxiliadoras nos seus processos decisórios, nas demais, a utilização fica restrita a atividades operacionais.

Outro ponto a ser considerado é o grau de importância que os tomadores de decisão destas empresas atribuem à tarefa de monitorar as informações dos seus ambientes de negócio. Nas empresas onde o tomador de decisão é mais consciente sobre essa importância, as ferramentas de apoio à decisão são mais utilizadas, chegando a proporcionar, conforme apresentado no capítulo anterior, mudanças nas estratégias do negócio.

A maneira como a informação extraída das ferramentas informatizadas ajuda os tomadores de decisão está diretamente relacionada à suas habilidades em manipular e analisá-las. Pode-se perceber nas pequenas empresas em que o proprietárioadministrador possui habilidades gerenciais e administrativas de análise, a utilização das informações é mais efetiva.

Com relação à existência de fatores que possam incrementar a utilização das ferramentas informatizadas de apoio à decisão nas pequenas empresas, notaram-se os seguintes deles:

- $\quad$ Existência de uma boa infra-estrutura tecnológica; 
- Consciência do proprietário-administrador com relação à utilização das informações como vantagem competitiva;

Presença de algum colaborador que possa auxiliar o tomador de decisão na utilização de ferramentas tecnológicas;

- Busca por melhorias internas, como aumento de produtividade e de vendas.

Em relação à existência de fatores que impeçam a utilização de ferramentas informatizadas por parte dos tomadores de decisão, observou-se nos três casos, que a dificuldade de manuseio, bem como, a falta de flexibilidade da ferramenta causa dificuldades aos proprietários-administradores, dificultando e até às vezes, impedindo a sua utilização.

Outro fator analisado que se supunha ser impeditivo com relação à utilização destas ferramentas é o volume de investimentos necessário para adquirir e mantê-las. No entanto, esse fator não foi constatado como de impedimento, pois de acordo com o observado nas empresas, as ferramentas são na maioria das vezes livres de licenças (navegadores de Internet, comunicadores instantâneos, algumas planilhas, groupware).

Existem casos de utilização de ferramentas não licenciadas, mas que de acordo com o percebido nas demais empresas pode ser tranquilamente substituída pelas de código aberto, sem a preocupação de ser perder a qualidade e as funcionalidades.

Diante do exposto, acerca da utilização das ferramentas informatizadas de apoio à decisão nas pequenas empresas pesquisas, e pautado pelo estudo das particularidades presentes na gestão e no processo decisório destas empresas, pode-se concluir que a utilização efetiva destas ferramentas está diretamente relacionada ao perfil e às habilidades de seus proprietários-administradores.

Com base no constatado pelos estudos de casos desta pesquisa, algumas ações tornam-se necessárias para permitir uma melhor interação dos tomadores de decisão das pequenas empresas com estas ferramentas, a fim de torná-las de fato apoiadoras do processo decisório, bem como geradoras de conhecimento organizacional para estas empresas.

Primeiramente, devem-se criar ambientes de aprendizagem, através de cursos e treinamentos internos, dirigidos à realidade destas empresas, onde o proprietárioadministrador possa adquirir conhecimentos necessários para manipular as ferramentas de apoio à decisão. 
Além disto, estes ambientes devem reforçar e demonstrar a importância da tomada de decisões com base em informações relevantes e confiáveis, as quais possam servir de parâmetros para a escolha das melhores alternativas de solução de um problema. Afinal, acredita-se que quanto mais informações precisas e confiáveis os tomadores de decisões possuírem, melhor será a delineação do problema e de suas alternativas, favorecendo, assim, a escolha da melhor solução.

Através de ações como estas, os administradores das pequenas empresas terão a chance de perceber a importância das ferramentas informatizadas como fonte de informação útil e de grande importância, facilitando e subsidiando a gestão e as tomadas de decisão em suas empresas. Além disso, acredita-se que com estas ações, a utilização destas ferramentas será incorporada facilmente à rotina de trabalho destes profissionais.

\subsection{LIMITAÇÕES DA PESQUISA}

A principal limitação percebida nesta pesquisa refere-se à impossibilidade de se generalizar as conclusões, tampouco validar estatisticamente determinadas proposições, uma vez que com apenas três pequenas empresas não é possível fazer afirmativas que possam ser estendidas a todas as pequenas empresas.

Entretanto, esta pesquisa por ter abordado o tema com um caráter qualitativo e exploratório, permitiu a familiarização com o objeto estudado, neste caso, as pequenas empresas e a utilização de ferramentas de apoio à decisão, abrindo caminho para estudos futuros.

\subsection{PROPOSIÇÃO DE ATIVIDADES FUTURAS}

Uma das principais propostas para estudos futuros é estender a problemática desta pesquisa para comprovações por meio de pesquisas quantitativas, avaliando-se assim, o panorama da presença das ferramentas de apoio à decisão nas pequenas empresas.

Além disso, é proposto explorar mais profundamente o universo das ferramentas informatizadas de apoio à decisão existentes no mercado, principalmente aquelas livres de licença. 


\title{
REFERÊNCIAS BIBLIOGRÁFICAS
}

\begin{abstract}
ALBUQUERQUE, A. F. (2004). Gestão estratégica das informações internas na pequena empresa: estudo comparativo de casos em empresas do setor de serviços (hoteleiro)... 209 p. Dissertação (mestrado). Escola de Engenharia de São Carlos, Universidade de São Paulo, São Carlos. 2004.
\end{abstract}

AMICCI, F. L. (2004). Software sob encomenda: um estudo exploratório de segmentação e posicionamento no mercado empresarial. 159 p. Dissertação (mestrado). Faculdade de Economia, Administração e Contabilidade, Universidade de São Paulo, São Paulo. 2004.

AQUARONI, L. M. (2001). Uma investigação sobre o relacionamento entre planejamento estratégico e sistemas de apoio à decisão. Dissertação (mestrado). Escola de Engenharia de São Carlos, Universidade de São Paulo, São Carlos. 2001.

ARGUELLO, N. (2002). Small is beautiful. Revista Sebrae, Brasília, n. 3.

AUGUSTA, E. C. G. (2001). Estratégia e sistemas de informação na empresa. Revista Eletrônica de Administração, Garça: ACEG/FAEF, a. 1, n. 1, dez. Disponível em http://www.revista.inf.br/adm01/pages/artigos/artigo05.htm. Acessado em 17/06/2004.

BEAL, A. (2004). Gestão estratégica da informação: como transformar a informação e a tecnologia da informação em fatores de crescimento e de alto desempenho nas organizações. São Paulo: Atlas.

BENZE, R. P.; CÊRA, K.; ESCRIVÃO FILHO, E. (2003). As especificidades contextuais, estruturais e comportamentais da pequena empresa: a importância de uma abordagem que integre os três conjuntos de características que influencia a gestão. In: SIMPÓSIO INTERINSTITUCIONAL DE ADMINISTRAÇÃO DO BOLSÃO SULMATOGROSSENSE E NOROESTE PAULISTA, 2., 2003, Três Lagoas. Anais... Três Lagoas, FIRB/UFMS/FAISA/FIU. 1CD-ROM.

BERALDI, L. C.; ESCRIVÃO FILHO, E. (2001). Caracterização dos recursos da tecnologia da informação na pequena empresa fabricante de móveis. In: SIMPEP SIMPÓSIO DE ENGENHARIA DE PRODUÇÃO, 6., 2001, Bauru. Anais... Bauru, UNESP.

BERALDI, L. C.; ESCRIVÃO FILHO, E.; RODRIGUES, D. M. (2001). Avaliação da adequação do uso da tecnologia da informação na pequena empresa. In: SIMPEP - 
SIMPÓSIO DE ENGENHARIA DE PRODUÇÃO, 6., 2001, Bauru. Anais... Bauru, UNESP.

BEUREN, I. M. (2000). Gerenciamento da informação: um recurso estratégico no processo de gestão empresarial. São Paulo: Atlas.

BIGATON, A. L. W. (2005). Gestão estratégica da informação nas pequenas empresas: estudo comparativo de casos em empresas do setor industrial de São José do Rio Preto. 200 p. Dissertação (mestrado). Escola de Engenharia de São Carlos, Universidade de São Paulo, São Carlos. 2005.

BISPO, C. A. F. (1998). Uma análise da nova geração de sistemas de apoio à decisão. 160 p. Dissertação (mestrado). Escola de Engenharia de São Carlos, Universidade de São Paulo, São Carlos. 1998.

CARDOZO, J. S. (2003). O empreendedorismo nosso de cada dia. Valor Econômico, São Paulo, 07 abr. Caderno b, p. 7.

CARVALHO, K. C. (2004). Gestão das informações sobre o ambiente na pequena empresa: estudo comparativo de casos sobre o processo estratégico no setor de serviços (hoteleiro) da região de Brotas - SP. 235 p. Dissertação (mestrado). Escola de Engenharia de São Carlos, Universidade de São Paulo, São Carlos. 2004.

CASTELLS, M. (1999). A sociedade em rede. São Paulo: Paz e Terra.

CAVALCANTI, M.; GOMES, E.; PEREIRA, A. (2001). Gestão de empresas na sociedade do conhecimento: um roteiro para a ação. Rio de Janeiro: Campus.

CAZARINI, A. (2002). Auxílio do data warehouse e suas ferramentas à estratégia de CRM analítico. 121 p. Dissertação (mestrado). Escola de Engenharia de São Carlos, Universidade de São Paulo, São Carlos. 2002.

CÊRA, K.; ESCRIVÃO FILHO, E. (2003). Particularidades de gestão da pequena empresa: condicionantes ambientais, organizacionais e comportamentais do dirigente. In: EGEPE - ENCONTRO DE ESTUDOS SOBRE EMPREENDEDORISMO E GESTÃO DE PEQUENAS EMPRESAS, 3., 2003, Brasília. Anais... Brasília, UEM/UEL/UnB, p. 796-812.

CERVO, A. L.; BERVIAN, P. A. (2002). Metodologia científica. 5. ed. São Paulo: Prentice Hall.

CHIAVENATTO, I. (2000). Introdução à teoria geral da administração. Rio de Janeiro: Campus. Cap. 19.

COLES, S.; ROWLEY, J. (1996). Spreadsheet modelling for management decision making. Industrial Management \& Data Systems, West Yorkshire: Emerald Group 
Publishing Limited, v. 96, n. 7, p. 17-23. Disponível em http://caliban.emeraldinsight.com. Acessado em 25/05/2004.

COLMANETTI, A. L. V. (2003). O uso da tecnologia de informação para promover a gestão do conhecimento: identificação de requisitos para a proposição de um modelo. 107 p. Dissertação (mestrado). Escola de Engenharia de São Carlos, Universidade de São Paulo, São Carlos. 2003.

COME, G. (2001). Contribuição ao estudo da implementação de data warehousing: um caso no setor de telecomunicações. 133 p. Dissertação (mestrado). Faculdade de Economia, Administração e Contabilidade, Universidade de São Paulo, São Paulo. 2001.

CRIE (2004). Centro de referência em inteligência empresarial. Universidade Federal do Rio de Janeiro. Disponível em http://www.crie.ufrj.br. Acessado em 28/11/2004.

DACORSO, A. L. R. (2000). Tomada de decisão e risco: a administração da inovação em pequenas indústrias químicas. 236 p. Dissertação (mestrado). Faculdade de Economia, Administração e Contabilidade, Universidade de São Paulo, São Paulo. 2000 .

DOUKIDIS, G.; LYBEREAS, P.; GALLIERS, R. D. (1996). Information systems planning in small business: a stage of growth analysis. Jornal of systens and software. May, v. 33, p. 189-201.

DUARTE, A. C. M (2004). Gestão estratégica na pequena empresa: estudo multicaso de identificação e análise do processo de formação de estratégia em pequenas empresas da região de Ribeirão Preto-SP. 182 p. Dissertação (mestrado). Escola de Engenharia de São Carlos, Universidade de São Paulo, São Carlos. 2004.

DRUKER, P. F. (1981). Práticas de administração de empresas. São Paulo: Pioneira.

DRUCKER, P. (2001). O melhor de Peter Drucker: obra completa. São Paulo: Nobel.

FGV (2004). Pesquisa anual: administração de recursos de informática. Disponível em http://www.fgvsp.br/academico/estudos/cia/index $\mathrm{r}$ pesq.htm. Acessado em $30 / 07 / 2004$.

FIATES, G.G. S. (2001). Avaliação de ferramentas da Internet para apoiar o desenvolvimento de organizações do conhecimento. Tese (doutorado). Universidade Federal de Santa Catarina, Florianópolis. 2001.

FREIRE, J. E. (2000). Uma abordagem sobre os colaboradores na atual sociedade da informação. 102 p. Dissertação (mestrado). Escola de Engenharia de São Carlos, Universidade de São Paulo. 2000. 
FREITAS, H.; KLADIS, C. M. (1995). O processo decisório: modelos e dificuldades. Revista Decidir, n. 8, mar.

GIL, A.C. (2002). Como elaborar projetos de pesquisa. 4. ed. São Paulo: Atlas.

GODOY, A. S. (1995). Introdução à pesquisa qualitativa e suas possibilidades. Revista de Administração de Empresas (RAE/FGV), São Paulo: EAESP/FGV, v. 35, n. 2, p. 57-63, mar./abr.

GREENFIED, L. (2004). A definition of decision support. The data warehousing information center. Disponível em http://www.dwinfocenter.org/decsup.html. Acessado em 11/05/2004.

GUERRINI, F. M. (2002). Planejar e redigir textos científicos em Engenharia de Produção. São Carlos: Serviço Gráfico da EESC-USP.

HOLSAPPLE, C. W.; WHINSTON, A. B. (1996). Decision support systems: a knowledge-based approach. Saint Paul: West Publishing Company.

HSM (2004). A gestão do conhecimento na prática. Revista HSM Management, São Paulo, ano 8, n. 42, p. 53-59, jan./fev.

LAUDON, K. C.; LAUDON, J. P. (2004). Sistemas de informação gerencias: administrando a empresa digital. São Paulo: Prentice Hall.

LEME FILHO, T. (2004). Business Intelligence no Microsoft Excel. Rio de Janeiro: Axcel Books do Brasil.

LEONE, N. M. C. P. G. (1991). A dimensão física das pequenas e médias empresas (P.M.E's): à procura de um critério homogeneizador. Revista de Administração de Empresas (ERA/FGV), São Paulo: EAESP/FGV, v. 31, n. 2, p. 53-59, abr./jun.

LEONE, N. M. C. P. G. (1999). As especificidades das pequenas e médias empresas. Revista de Administração da USP (RAUSP), São Paulo: FEA/USP, v. 34, n. 2, p. 91 94, abr./jun.

LONGENECKER, J. G.; MOORE, C. W.; PETTY, J. W. (1997). Administração de pequenas empresas: ênfase na gerência empresarial. São Paulo: Makron Books.

MARCONI, M. A.; LAKATOS, E. M. (2002). Técnicas de pesquisa: planejamento e execução de pesquisas, amostragens e técnicas de pesquisas, elaboração, análise e interpretação de dados. 5. ed. São Paulo: Atlas.

MARCONI, M. A.; LAKATOS, E. M. (2003). Fundamentos de metodologia científica. 5. ed. São Paulo: Atlas. 
MARQUES, I. C. (1999). Desmaterialização e trabalho. In: LASTRES, H. M. M.; ALBAGLI, S. (Org.). Informação e globalização na era do conhecimento. Rio de Janeiro: Campus. Cap. 8, p. 191-215.

MEIRELLES, F. S. (1994). Informática: novas aplicações com microcomputadores. São Paulo: Makron Books.

MELO, G. B. (2001). A notícia dos pequenos negócios. Revista Sebrae, Brasília, n. 2.

MICROSOFT (2005). Microsoft builds business intelligence into Office Software: availability of Microsoft Office Business Scorecard Manager 2005... Disponível em http://www.microsoft.com./presspass/press/2005/oct05/10-23BiLaunchPR.mspx. Acessado em 25/10/2005.

MIGLiATO, A. L. T. (2004). Planejamento estratégico situacional aplicado à pequena empresa: estudo comparativo de casos em empresas do setor de serviço (hoteleiro) da região de Brotas - SP. 223 p. Dissertação (mestrado). Escola de Engenharia de São Carlos, Universidade de São Paulo, São Carlos. 2004.

MIGLIOLI, A. M.; OSTANEL, L. H.; TACHIBANA, W. K. (2004). Planilhas eletrônicas como ferramentas para apoio à decisão e geração de conhecimento na pequena empresa. In: ENEGEP - ENCONTRO NACIONAL DE ENGENHARIA DE PRODUÇÃO, 24., 2004, Florianópolis. Anais... Florianópolis, UFSC.

MORAIS, E. F. C. (Coord.) (1999). Inteligência competitiva: estratégias para pequenas empresas. Brasília: GH Comunicação Gráfica Ltda.

NAKAMURA, M. M.; ESCRIVÃO FILHO, E. (1998). Estratégia empresarial e as pequenas e médias empresas: um estudo de caso. In: ENEGEP - ENCONTRO NACIONAL DE ENGENHARIA DE PRODUÇÃO, 18., 1998, Niterói. Anais... Niterói.

O'BRIEN, J. (2003). Sistemas de informação e as decisões gerenciais na era da Internet. São Paulo: Saraiva.

OSTANEL, L. H. (2005). Uma proposta de utilização da Internet como suporte informacional à gestão da pequena empresa. 132 p. Dissertação (mestrado). Escola de Engenharia de São Carlos, Universidade de São Paulo, São Carlos. 2005.

PAIVA, W. P. (2002). Avaliação de habilidades para a tomada de decisão em administração de empresas: um estudo descritivo com alunos de graduação da FEAUSP. 115 p. Dissertação (mestrado). Faculdade de Economia, Administração e Contabilidade, Universidade de São Paulo, São Paulo. 2002.

PEGN (2002). Roteiro para vencer em 2002. Revista Pequenas Empresas Grandes Negócios, São Paulo: Globo, n. 156, p. 21, jan. 
PEMBERTON, J. D.; ROBSON, A. J. (2000). Spreadsheets in business. Industrial Management \& Data Systems, West Yorkshire: Emerald Group Publishing Limited, v. 100, n. 8, p. 379-388. Disponível em http://caliban.emeraldinsight.com. Acessado em $25 / 05 / 2004$.

PEREIRA, R. O. (2000). Gestão do conhecimento na indústria: uma proposta de avaliação da gestão do conhecimento para indústria do setor moveleiro da região metropolitana de Curitiba. Dissertação (mestrado). Universidade Federal de Santa Catarina. Florianópolis. 2000.

PINHEIRO, M. (1996). Gestão e desempenho das empresas de pequeno porte. Dissertação (doutorado). Faculdade de Economia e Administração, Universidade de São Paulo, São Paulo. 1996.

POWER, D. J. (2003). A brief history of spreadsheets. DSSResources.COM. Disponível em http://dssresources.com/history/sshistory.html. Acessado em 11/05/2004.

PRATES, G. A.; OSPINA, M. T. (2004). Tecnologia da informação em pequenas empresas: fatores de êxito, restrições e benefícios. Revista de Administração Contemporânea, Rio de Janeiro: ANPAD, v. 8, n. 2, p. 9-26, abr./jun.

QUELOPANA, E. M. (2003). Conhecimento e decisão: um estudo sobre a relação entre o conhecimento e a qualidade de decisão. 141 p. Dissertação (mestrado). Faculdade de Economia, Administração e Contabilidade, Universidade de São Paulo, São Paulo. 2003.

RODRIGUEZ, M. V. R. (2002). Gestão empresarial: organizações que aprendem. Rio de Janeiro: Qualitymark.

SANTOS, M. (1998). Fora de foco: por que boa parte das pequenas empresas não consegue tirar vantagens efetivas da informática e da informação. Revista Pequenas Empresas Grandes Negócios, São Paulo: Globo, n. 108, p. 60-61, fev.

SAUER, L.; COLOSSI, N. (1997). A visão das associações comerciais e industriais de Santa Catarina sobre os fatores de sucesso de pequenas e médias empresas. In: ENEGEP - ENCONTRO NACIONAL DE ENGENHARIA DE PRODUÇÃO, 17. 1997, Gramado/Canelas. Anais... Gramado/Canelas.

SBA (2004). What is Small Business? Disponível em http://www.sba.gov/businessop/. Acessado em 19/07/2004.

SCHERMERHORN JÚNIOR, J. R. (1999). Administração. Rio de Janeiro: LTC.

SEBRAE (2003a). Sobrevivência e mortalidade das empresas paulistas de 1 a 5 anos: relatório final. Disponível em http://www.sebraesp.com.br. Acessado em $12 / 04 / 2004$. 
SEBRAE (2003b). A informática nas MPEs paulistas: relatório de pesquisa. Disponível em http://www.sebraesp.com.br. Acessado em 12/04/2004.

SEBRAE (2004a). Conhecendo a pequena empresa. Disponível em http://www.sebraesp.com.br/. Acessado em 19/07/2004.

SEBRAE (2004b). Estudos e pesquisas. Disponível em http://www.sebrae.com.br/. Acessado em 19/07/2004.

SILVA, T. D. (2002). O estudo de caso: a preferência metodológica na produção discente do Núcleo de Pós-Graduação em Administração... Caderno de pesquisas em administração: programa de pós-graduação em administração da FEA/USP, São Paulo: FEA/USP, v. 9, n. 3, p. 81-88, jul./set.

SOUZA, M. C. A. F. (1995). Pequenas e médias empresas na reestruturação industrial. Brasília: Sebrae.

SPRAGUE JÚNIOR, R. H. (1991). Estrutura para o desenvolvimento de sistemas de apoio à decisão. In: SPRAGUE JÚNIOR, R. H.; WATSON, H. J. (Org.). Sistema de apoio à decisão: colocando a teoria em prática. Rio de Janeiro: Campus. Cap. 1, p. 942.

SPRAGUE JÚNIOR, R. H.; WATSON, H. J. (1991). Sistema de apoio à decisão: colocando a teoria em prática. Rio de Janeiro: Campus.

STAIR, R. M.; REYNOLDS, G. W. (2002). Princípios de sistemas de informação. Rio de Janeiro: LTC.

STONER, J. A. F. (1999). Administração. 5. ed. Rio de Janeiro: LTC.

TAFNER, M. A.; TAFNER J.; FISCHER, J. (1999). Metodologia do trabalho acadêmico. Curitiba: Juruá.

TERENCE, A. C. F. (2002). Planejamento estratégico como ferramenta de competitividade na pequena empresa: desenvolvimento e avaliação de um roteiro prático para o processo de elaboração do planejamento. 208 p. Dissertação (mestrado). Escola de Engenharia de São Carlos, Universidade de São Paulo, São Carlos. 2002.

TERENCE, A. C. F.; ESCRIVÃO FILHO, E. (2001). O planejamento estratégico nas pequenas empresas: a importância da análise ambiental para a competitividade das pequenas organizações. In: SIMPEP - SIMPÓSIO DE ENGENHARIA DE PRODUÇÃO, 8., 2001, Bauru. Anais... Bauru, UNESP.

TRIVIÑOS, A. N. S. (1992). Introdução à pesquisa em ciências sociais: a pesquisa qualitativa em educação. São Paulo: Atlas. 
TURBAN, E. (1995). Decision support and expert systems: management support systems. Upper Saddle River: Prentice-Hall.

VIOTTI, A. P. S.; BRAGA, J. L. (1998). Uma ferramenta de geração de sistemas de apoio à decisão. In: SPG'98 - SEMANA DE PÓS-GRADUAÇÃO EM CIÊNCIA DA COMPUTAÇÃO, 2., 1998, Belo Horizonte. Anais Eletrônicos... Belo Horizonte: UFMG. Disponível em http://www.dcc.ufmg.br/pos/html/spg98. Acessado em 09/08/2004.

YIN, R. K. (2005). Estudo de caso: planejamento e métodos. 3. ed. Porto Alegre: Bookman.

ZAMARIOLI, R. (2003). Participação e tomada de decisão na pequena empresa: estudo multi-casos em três empresas industriais do ramo metalúrgico de Ribeirão PretoSP. 338 p. Dissertação (mestrado). Escola de Engenharia de São Carlos, Universidade de São Paulo, São Carlos. 2003.

ZAMARIOLI, R.; BENZE, R. P.; ESCRIVÃO FILHO, E. (2003). Participação e tomada de decisão na pequena empresa: estudo multi-casos em três empresas industriais do ramo metalúrgico de Ribeirão Preto-SP. In: SIMPÓSIO INTERINSTITUCIONAL DE ADMINISTRAÇÃO DO BOLSÃO SUL-MATOGROSSENSE E NOROESTE PAULISTA, 2., 2003, Três Lagoas. Anais... Três Lagoas, FIRB/UFMS/FAISA/FIU. 1CD-ROM. 